
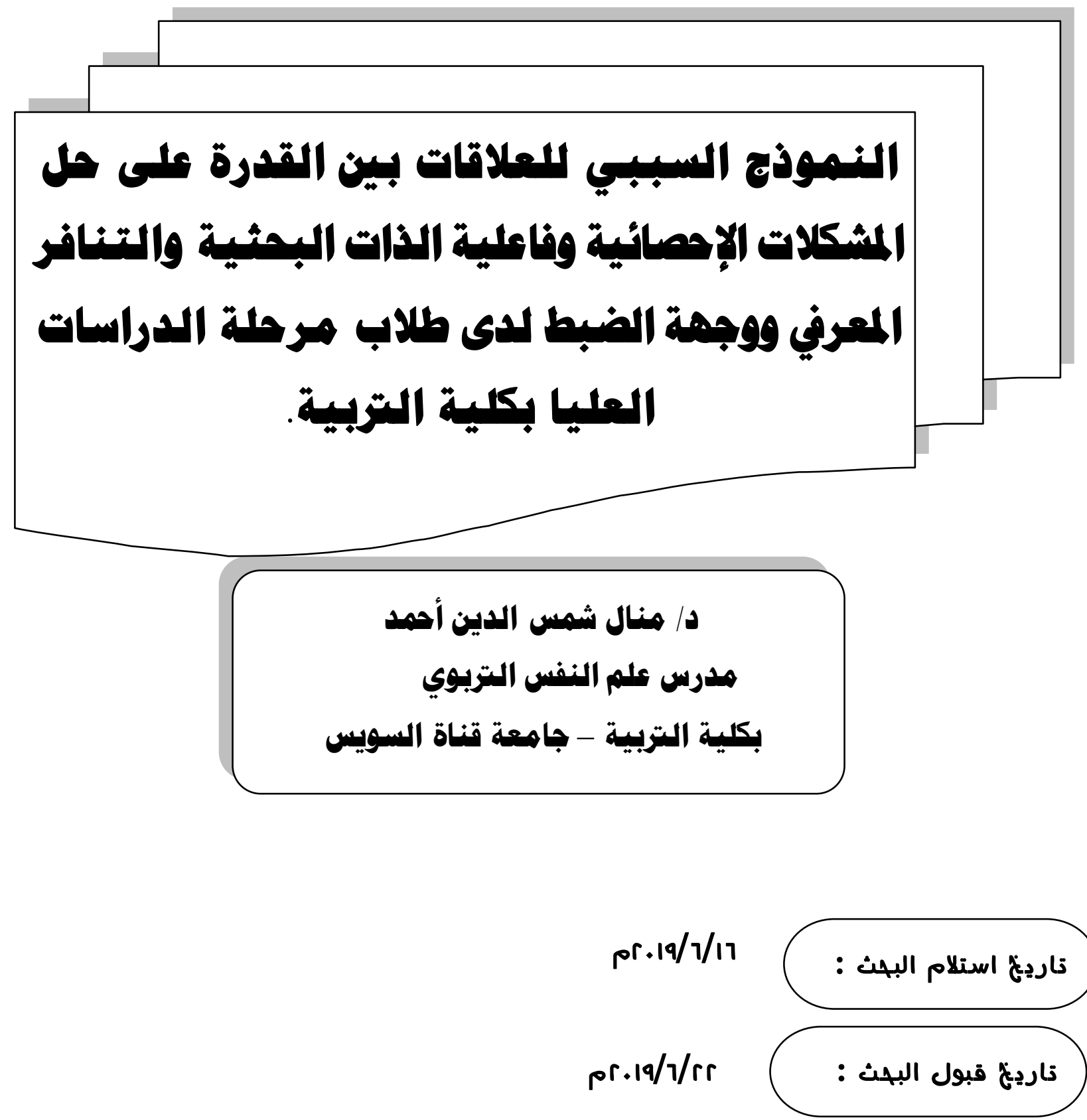


\section{ملغص البجيث}

يرهاف البحث الحالي إلى الكثف عن مستوى التنافر المعرفي ومستوى فاعلية الذات البحثية لاى طلاب الاراسات العليا بكلية التربية بجامعة قناة السويس، تحديد وجهة الضبط (داخلي -خارجي) لايهم، والكثف عن الفروق في القدرة على حل المشكلات الإحصائية لاى طلاب الدراسات العليا بكلية

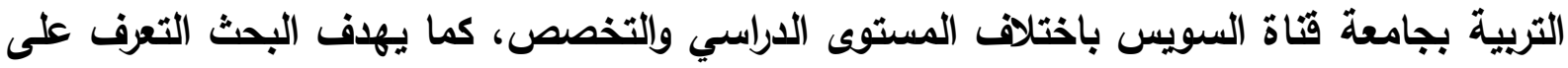
أفضل نموذج العببي يفسر العلاقات بين القدرة على حل المشكلات الإحصائية، وأبعاد التنافر المعرفي (الثخصي، والإجتماعي)، وأبعاد فاعلية الذات البحثية (المبادأة والمثابرة، تحمل المسئولية البحثية، الثقة بالنفس)، ووجهة الضبط لاى عينة البحث.

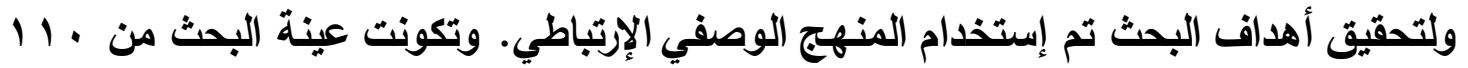

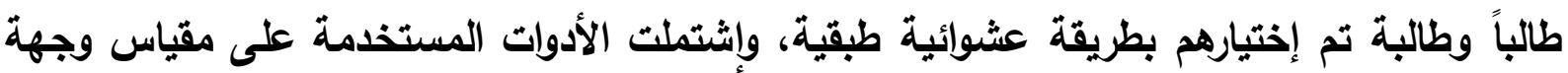

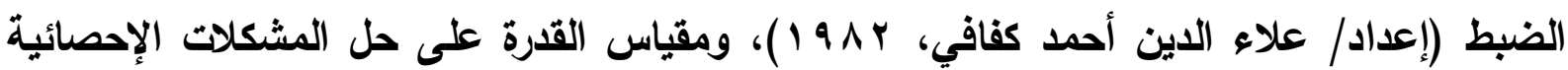

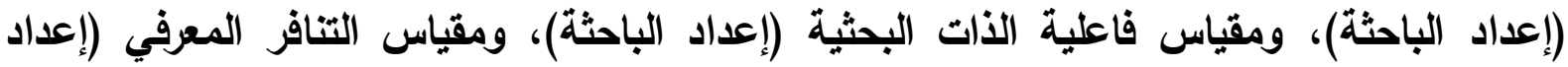

ويعد تحليل البيانات إحصائياً؛ توصلت نتائج البحث إلى أن طلاب الدراسات العليا بكلية التربية

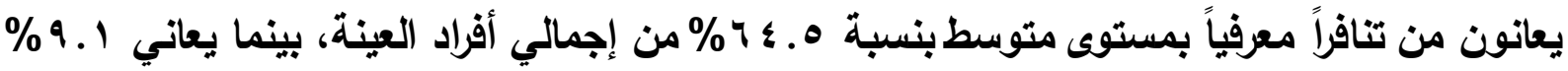

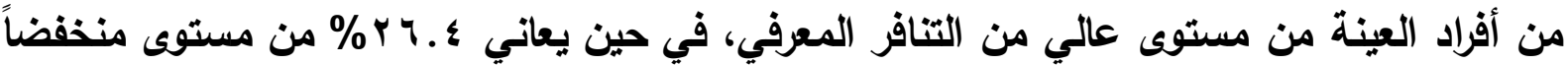
من التنافر المعرفي. كما أثارت النتائج إلى أن طلاب الدراسات العليا بكلية التربية لايهم معتقدات وتصورات حول أمكانياتهم للإنتاجية البحثية وأداء مهامهم البحثية بمستوى مرتفع بنسبة 9 . ـ ؟\% من

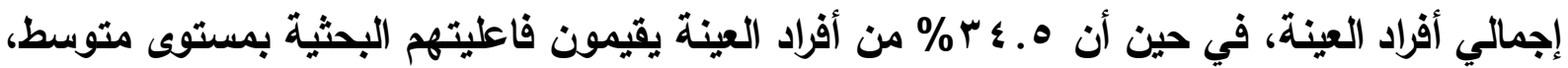
بينما يرى ه.ء\% من الطلاب أن إستعداداتهم لإنجاز المهام المرتبطة بالبحث العلمي بمستوى

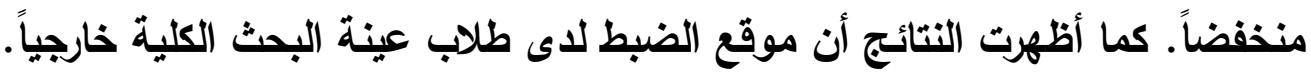
وأشارت النتائج إلى وجود فروق ذات دلالة إحصائية في القدرة على حل المشكلات الإحصائية لاى طلاب الدراسات العليا باختلاف المستوى الدراسي (دبلوم خاص، والماجستير، والدكتوراه). كما أثشارت النتائج إلى وجود تأثيرات سبيية دالة لأبعاد فاعلية الذات البحثية (المبادأة والمثثابرة، وتحمل المسئولية البحثية) على القدرة على حل المشكلات الإحصائية، ووجود تأثير سببي مباشر سالب دال إحصائياً للتنافر المعرفي الثخصي على القدرة على حل المشكلات الإحصائية، ووجود تأثير سببي علئي مباشر سالب دال إحصائياً للتنافر المعرفي الثخصي على الثقة بالنفس (أحد أبعاد فاعلية الذاتهات البحثية)، ووجود تأثيرات سبيية للتنافر المعرفي الإجتماعي في أبعاد فاعلية الذات البحثية (المبادأة

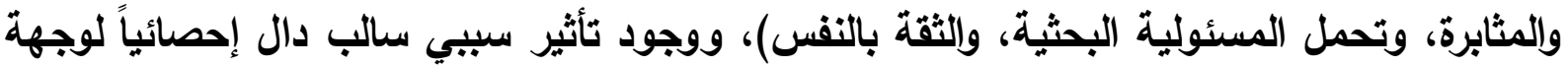


النموذج السبي للعلاقات بين القدرة على حل المشكلات الإحصائية وفاعلية الذات البحثية والتنافر المعرفي ووجهة الضبط لدى طلاب مي حلة الدراسات العليا بكلبة التبية.

الضبط على أبعاد فاعلية الذات البحثية (الثقة بالنفس، تحمل المسئولية البحثية). وأوصت الدراسة

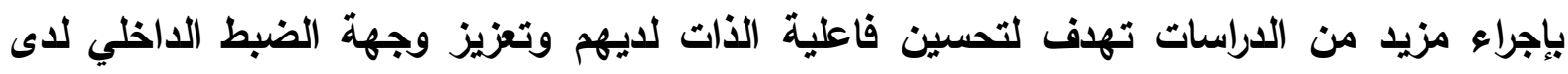

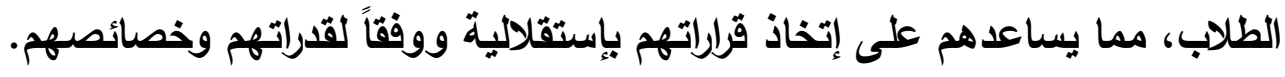

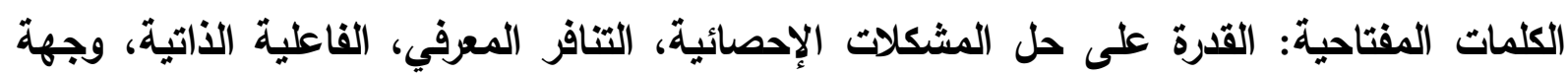
الضبط. 


\section{مقدمة}

أهم ما يميز الانسان عن باقي المخلوقات هو القدرة على حل المشكلات التي تواجهه في

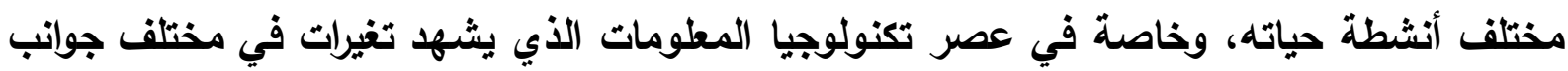
الحياة. ويرى كونان (Konan, 2013) أن القدرة على حل المشكلات تعد أحد عوامل النجاح الثخصي، ولذا تسعى المجتمعات المتقدمة إلى تنمية قدرة أفرادها على تفسير البيانات المقدمة في

شكل رسوم بيانية وإلتنبؤ بها.

ويواجه الفرد أعداداً لا حصر لها من المشكلات في حياته اليومية؛ مما يحتم عليه إعداد خططاً

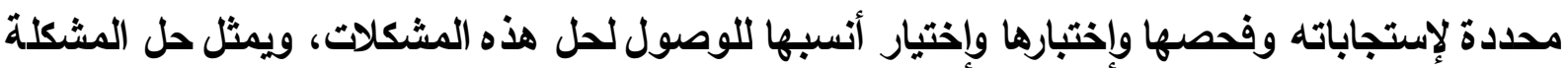
تفكيراً موجهاً نحو هدف معين، مع القيام بنوعين من النشاط العقلي؛ هما التوصل إلى إستجابات

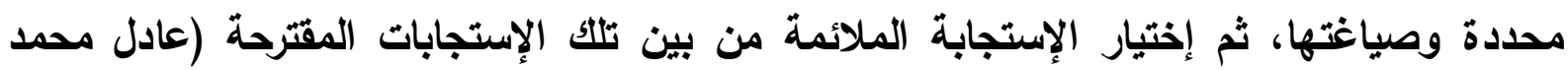
العدل، وصلاح شريف عبد الوهاب، ب . . ب ).

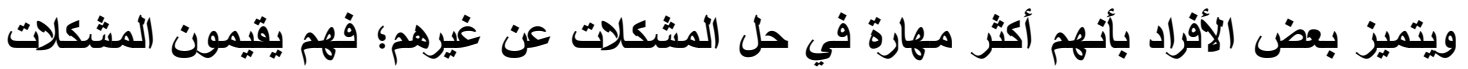

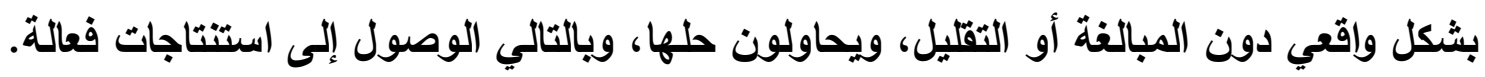

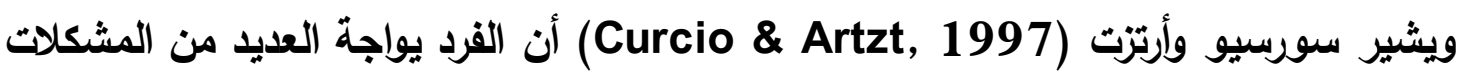
الإحصائية التي تتطلب تحليل البيانات ليس فقط عند دراسة الإحصاء، بل في تخصصات أخرى عديدة مثل الرياضيات والطلوم الفيزيائية والعلوم البيولوجية وكذلك العلوم الإجتماعية.

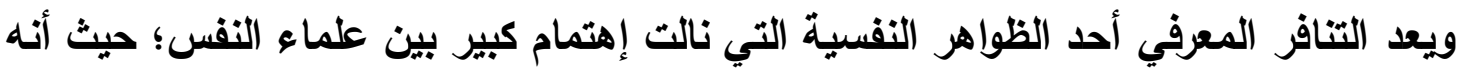
يعبر عن الحالة الإنفعالية التي تنشأ عندما يكون الفرد في موقف متعارض مع ما يعتقده من آراء ومعتقات واتجاهات وما ينسجم مع مواقفه. ويؤثر على أداء الفرد في كثير من المواقق وخاصة

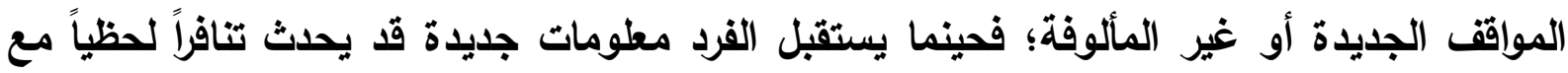
المعارف الموجود بالبنية المعرفية ويؤثر على التناغم المعرفي لدى الفرد. وهذا ما قد يتعرض لله الفرد في مواقف التفكير وحل المشكلات الصعبة والمعقدة. فتفترض نظرية التنافر المعرفي وجود دافع لدى الفرد للحفاظ على الاتساق بين أفكاره

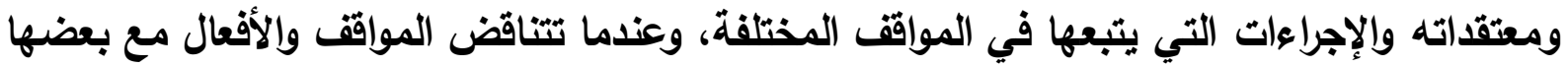
البعض، ينتج عن ذلك الثعور بالاتزعاج النفسي، مما يؤدي إلى تولد دافع لاستعادة الاتساق عن

طريق تغيير المعتقدات لإعادة توافقها مع السلوك (Balcetis \& Dunning, 2007). فعلى الفرد أن يسعى جاهداً لتحقيق التوازن بين معتقداته ومعارفه في النسق المعرفي الخاص به وما يقوم به من سلوكيات في المواقف المختلفة، كما يجب أن يكون التصور الذاتي للفرد في بيئة تعليمية أو مهنية جديدة غير مأكوفة في إتجاه إيجابي، وإلا سيعاني الفرد من تنافر معرفي 
Antoniou, Doukas \& Subrahmanyam, 2013) الخاصة مطلبًا أساسيًا من أجل تحقيق أهدافه بنجاح والتظلب على الصعويات التي تواجهه.

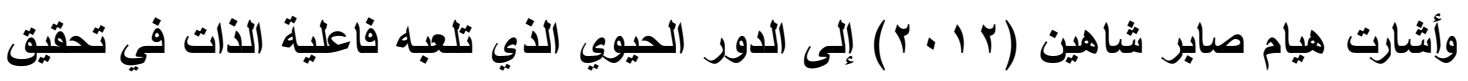

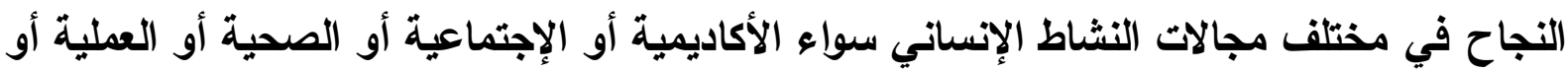

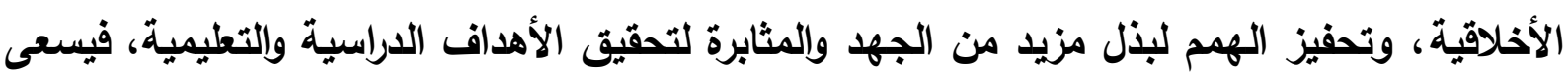
الفرد جاهداً لتحقيق أهدافه إذا إعتقد في قدرته على إنجاز النتائج المرغوب فيها بمجهوده الثخصي.

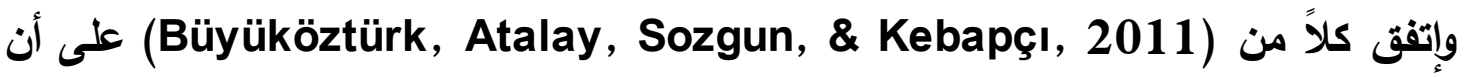
فاعلية الذات البحثية تمثل أحد محدات الأداء في مجال البحوث العلمية تبحث عن حول للمشكلات

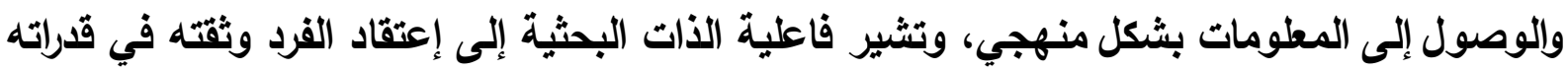
على تنفيذ أو إكمال المهام البحثية بنجاح مثل مراجعات الأدب وتحلئل واتيل البيانات.

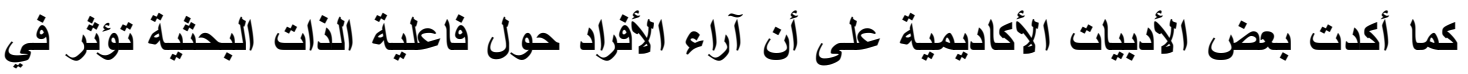

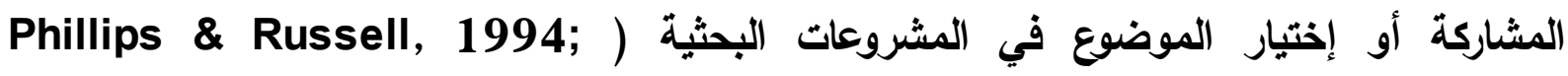
.(Forester, Kahn, \& Hesson-Mclnnis, 2004 وفي العقود الأخيرة، أصبح مفهوم "وجهة الضبط" شائعاً على نطاق واسع في التعليم، لما له

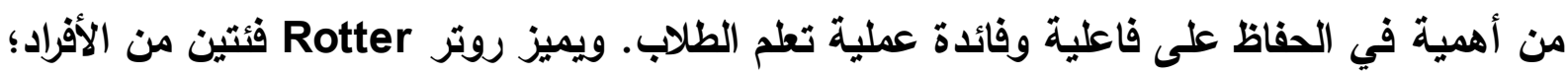
ذوي الضبط الداخلي الذين يفسرون نتائج أعمالهم سواء الإيجابية أو السلبية لقدراتهم وإمكاناتهر ومجهوداتهم، في حين يصرح ذوي الضبط الخارجي بأن العوامل الخارجية هى التي تتحكم في سلوكهاء الإبها وعزو نتائج الأداء الناجح وغير الناجح للحظ أو الصدفة. (Devi \& Saravanakumar, 2017).

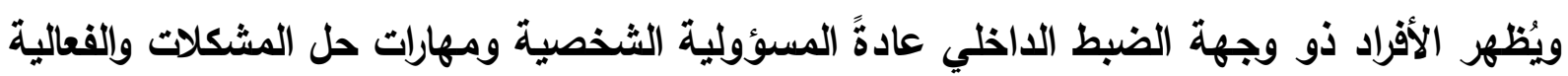

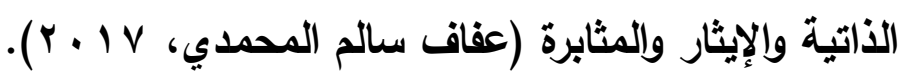

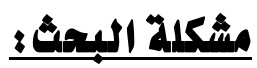

يشهر العصر الحالي اهتماماً كبيراً بالبحث العلمي وإعداد باحثين متميزين قادرين على رصد

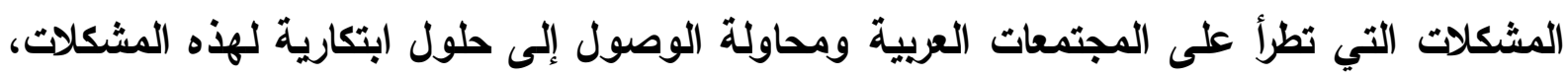

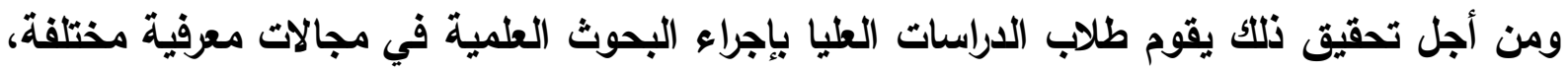

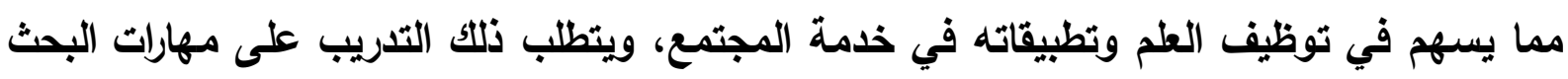

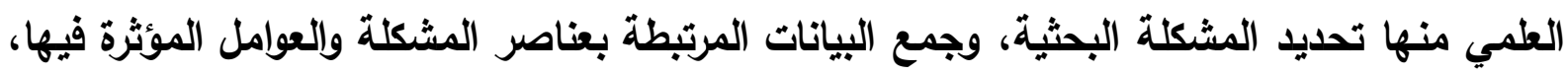
ووضع الفرضيات، وتصميم وإجراء التجارب البحثية اللازمة لإختبارها، وإستخلاص النتائج وتفسيرها ثم 
ولاحظت الباحثة من واقع عملها كعضو هيئة تدريس، أن طلاب الاراسات العليا بمرحلتي الماجستير والدكتوراه يواجهون مجموعة من الصعويات عند تصميم وتنفيذ خططهم البحثية منها ضعف لإنف القدرة على تحديد المشكلة والتعبير غنها، وعدم القدرة على التمييز بين متفيراتها والعلاقات بينها،

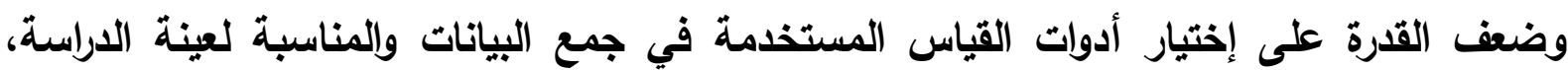

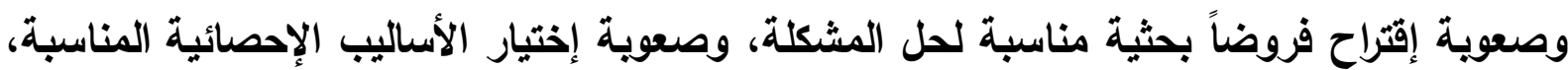

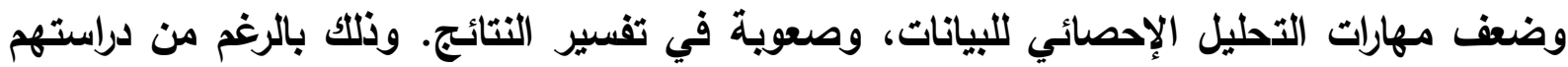

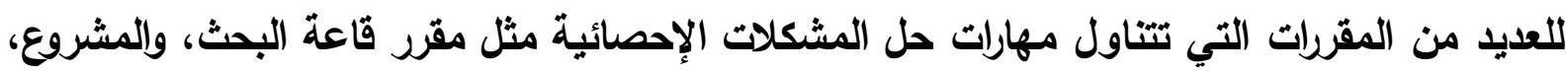
والإحصاء النفسي الوصفي والإستدلالي؛ إلا أنهم يجدون صعوية في تطبيق تلك المطومات وات والخبرات

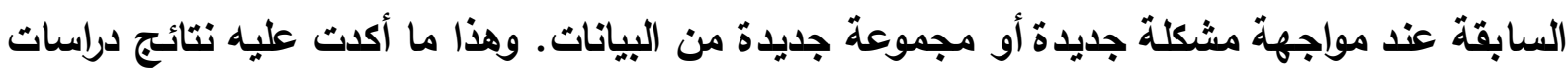

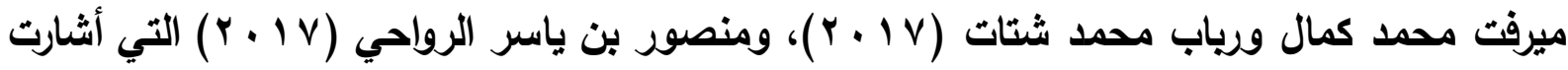
إلى إنخفاض قدرة الطلاب على حل المشكلات الاحصائية. وفي ظل عصر المطومات وإلتكنولوجيا يعد تطوير وتتمية قدرة المتعمين على حل المشكلات

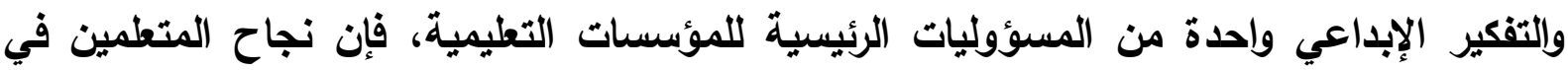
حياتهم يعتمد إلى حد كبير على هذه القدرات (Chandra, 2014)؛ مما دعا الباحثة إلى الاهتمام

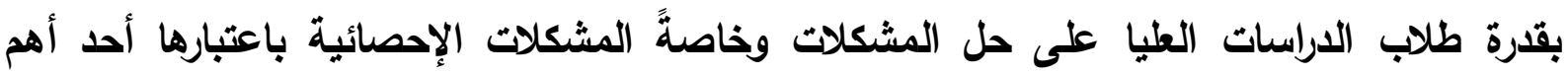
مهارات البحث العلمي. وفي الوقت الذي تزداد فيه أهمية التمسك بالمهارات البحثية والمبادئ الأخلاقية لاى طلاب

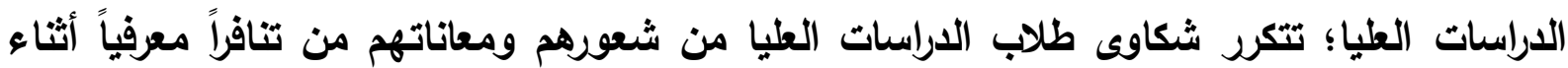

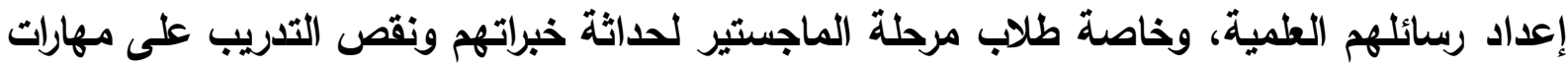

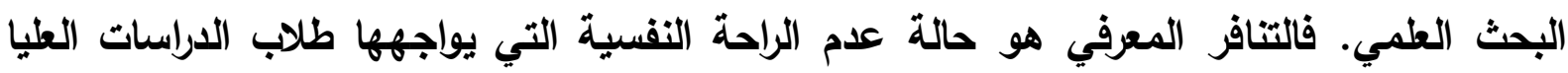
نتيجة الإختلاف بين ما تعلموه من ومهارات ومعارف مخزنة لديهم في بنيتهم المعرفية وبين ما يتنبنوه

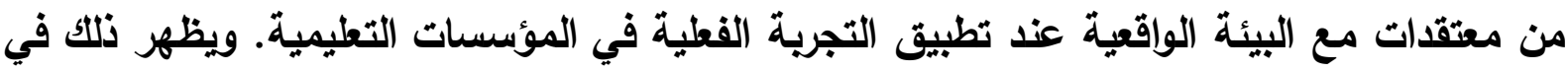

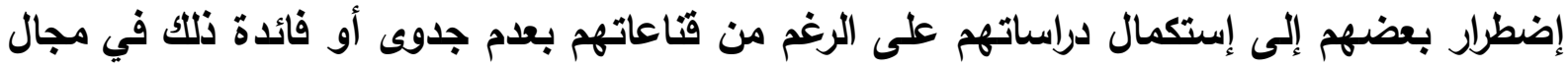

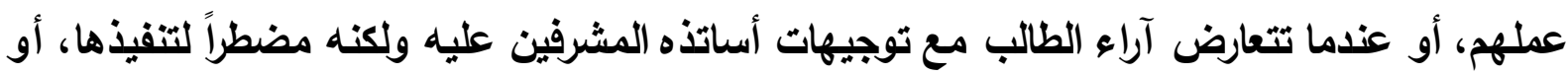

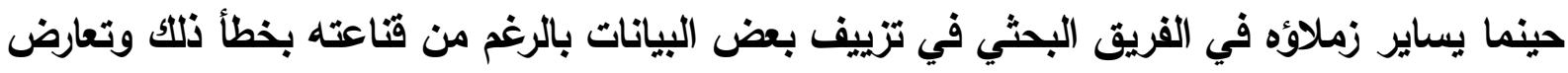

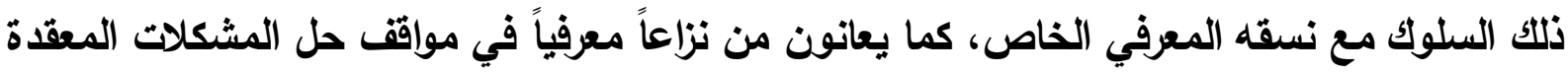

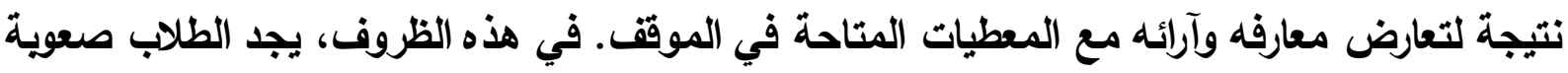
في التعامل مع المواقف الصعبة، ويعانون من صراع معرفي بين معتقداتهم وأفكارهم الخاصة والسلوكيات التي يقومون بها؛ مما يتسبب بشعورهم بالتوتر. 


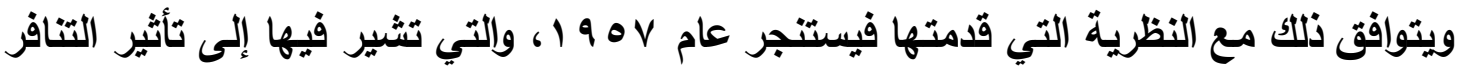

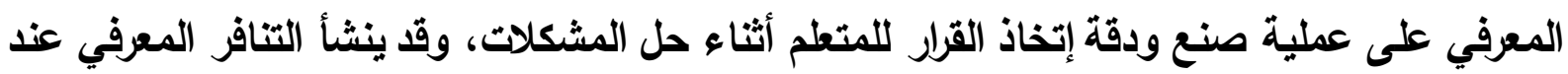

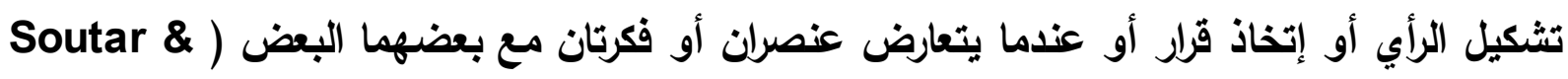

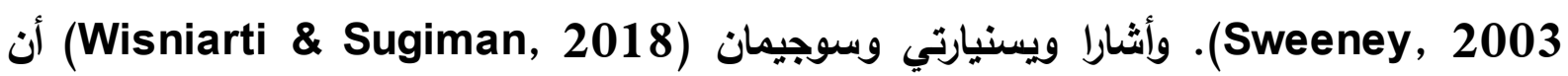
التنافر المعرفي قد يحدث عند حل مثكلة غير روتينية، ويشعر حينها الطلاب بعدم الإرتياح ويواجهون صعويات أثناء حل تلك المشكلات. وهذا ما أكده دفي وسارافاناكومار (Devi \& Saravanakumar, 2017) حيث أشثار أن المعلمون حديثي التعيين يواجهون تنافراً معرفياً، نتيجة عدم الخبرة ونقص التدريب، نتيجة إختلاف

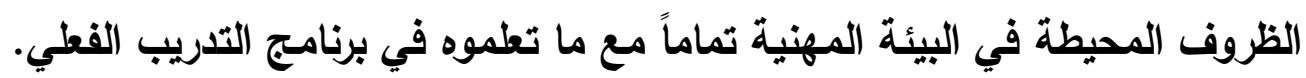
ويتمكن طالب الدراسات العليا من تحقيق التوازن بين ما يعتقده في نسقامه المعرفي، وأفعاله التي يقوم بها في مواقف التعم، من خلال تحليل المشكلات والمواقف الجديدة غير المألوفة وتحديد لمايد الأسباب الحقيقية لهذه المشكلات، ومعالجة الموقف بتفضيل العناصر المعرفية الإيجابية مثل الإلتزام بالأمانة العلمية وتنفيذ تعليمات أساتذته لخبراتهم السابقة ومحاولة الإستفادة من دراستهم العلمية في مجال عملهم وتوظيف معارفهم مما يشعرهم بجدوى دراستهم وعدم إهدار الوقت والجهد.

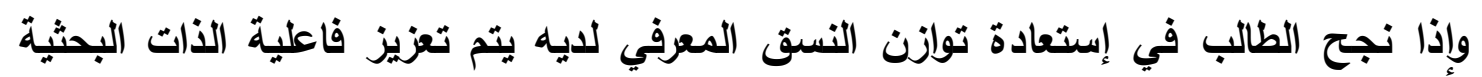
المدركة؛ حيث تعمل معارف الفرد حول ذاته كمصادر لتخفيض التتافر المعرفي، وتؤثئر على الأداء الثخصي في العديد من المجالات. وتعد فاعلية الذات أحد متغيرات الثخصية التي تلعب دوراً بارناً في إحداث الفروق بين الأفراد

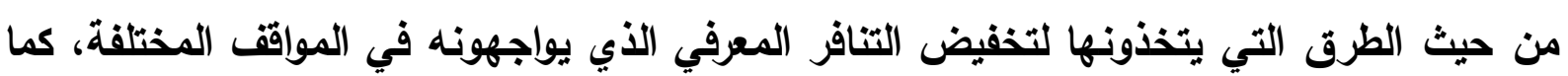
تعد من العوامل المهمة في تفسير سلوك الفرد، فيختلف الأفراد فيما بينهم في استجاباتهم للمواقف يوفي

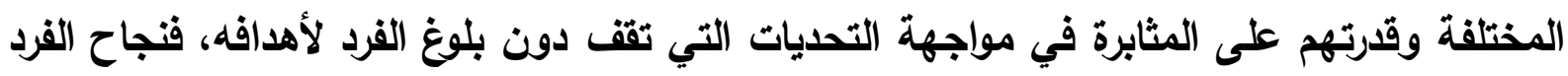
يعتمد على توقعاته وأحكامه حول المهارات السلوكية التي يمتلكها وملائمتها في تخطي تحديات البيئة المحيطة به. وهذا ما أكلت عليه هيام صابر شاهين (r ( ب r)؛ فأوضحت أن إدراك الفرد لفعالية ذاته أي إدراكه لما يمتلكه قدرات وامكانيات، يمثل الأساس الأي تستتد عليه أهدافه وطموحاته وإلخطط التي

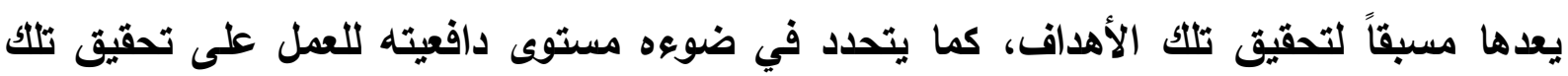

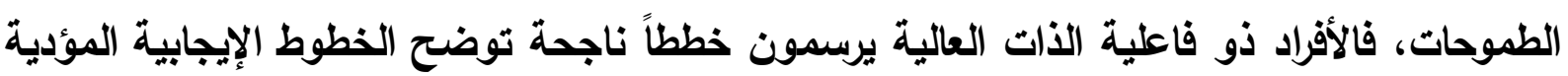

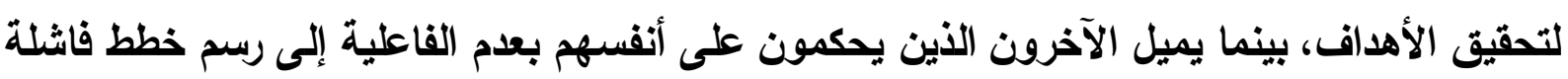
مما يجعل المستقبل أمامهم مظلماً. 
وتثير فاعلية الأت البحثية إلى قدرة طلاب الاراسات الطليا على تثفيذ مهام تتطلى بإجراء البحوث العلمية، وأشثارت بعض الدراسات إلى القدرة التبوئية لفاعلية الأت البحثية بالأداء الأكاديمي Gelso, Mallinckrodt \& Judge, 1996; ) والانتاجية البحثية لاى طلاب الدراسات العليا Büyüköztürk, Atalay, Sozgun, \& Kebapçı, 2011; Tella, Ayeni \& Omba, 2007) ولألك اهتم البحث الحالي بدراسة فاعلية الأت البحثية لاى طلاب الاراسات العليا. وأشارت دراسة أمل اسماعيل ارنوط (v v r r ) إلى انخفاض فاعلية الأات البحثية لاى طلاب الدراسات العليا بمرحلتي الماجستير والدكتوراه بالجامعات الحكومية في عدد من البلاد العربية. واتفقت بعض الدراسات (مثل: Butler, 2008 أمل عبد المحسن الزغبي، r I . r) على وجود علاقة موجبة بين فاعلية الأت والقدرة على حل المشكلات. ومن زاوية أخرى؛ فقد لاحظت الباحثة إستياء بعض طلاب الدراسات العليا من نتائجهم في مقرر الإحصاء النفسي، وتكرار خبرات فشلهم في إجتياز الإختبارات الدورية؛ ويرجعون ذلك لقصر وقت الإختبار أو لعدم توفر وقت للإستذكار مع ضغوط العمل والظروف الأسرية أو لصعوية المادة، في حين يفسر البعض إخفاقهم في إجتياز إختبارات الإحصاء لعدم بذلهم مزيد من الجها والتدريب على نماذج أخرى من التمارين، أو لعدم فهمهم الجيد لبعض الأجزاء نتيجة لعدم حضورهم المحاضرات بإنتظام. وقد تفسر تلك الملاحظات والشكاوى في ضوء مفهوم "وجهة الضبط" الأي ظهر في العقود الأخيرة، وأصبح مفهوماً شائعاً على نطاق واسع في التعليم، لما له من أهمية في الحفاظ على فاعلية وفائدة عملية التعلم لاى الطلاب. ويعد مفهوم وجهة الضبط مفهوماً ثنائي القطب تتراوح فيه درجات الأفراد بين ضبط داخلي وضبط خارجي، فالأفراد يعتبرون أن النتائج تعزز سلوكهم كعزو النجاح أو الفشل في تحقيق هدف ما، إما بسبب عوامل داخلية (مثل الجهد المبذول)، أو لعوامل خارجية (مثل

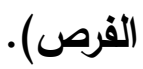
ويعبر مفهوم "وجهة الضبط" عن ما يتبناه الفرد من معثقدات يعزو إليها نتائج أعماله في المواقف أو المهام وأسباب المشكلات التي تواجهه، فيمثل بذلك أحد العوامل الهامة في تفسير سلوكيات الأفراد في المواقف المختلفة. ويعتقد روكسترو Rockstraw أن الأفراد الأين يمتلكون وجهة ضبط داخلي وفاعلية ذات عالية يستمرون في أداء مهماتهم لأوقات أطول من الأفراد منخفضي

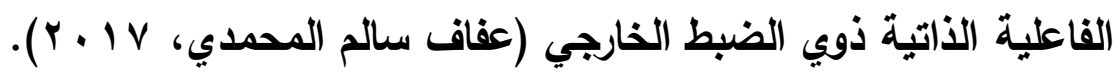
وتوصلت دراسة كونان (Konan, 2013$)$ إلى إرتباط وجهة الضبط الااخلية إيجابياً بالقدرة على حل المشكلاث، كما أوضحت دراسة عفاف سالم المحمدي (Y . P ) ودراسة كاريفيو وروداس (Carifio, Rhodes, 2002) وترى الباحثة أن أداء طالب الدراسات العليا عند تصميم وتتفيذ خطته البحثية قد يتأثز بقرته على حل 
المشكلات الإحصائية، وفاعلية الذات البحثية، وموضع التحكم. وهذا ما يسعى البحث الحالة من التحقق منه.

ويمكن تلخيص مشكلة البحث الحالي في التقاط التالية:

Butler, 2008; Zheng, McAlack, Wilmes, Evans, \& (الدعدداسات Williamson, 2009; Konan, 2013; Wisniarti \& Sugiman, 2018 القدرة على حل المشكلات "أو مهارات حل المشكلات" وعلاقتها بالمتغيرات التفسية الأخرى، مثل التنافر المعرفي، وفاعلية الأات، ووجهة الضبط. r. عدم وجود دراسات سابقة (في حدود المسح المتاح) تتاولت التتافر المعرفي لاى طلاب مرحلة الاراسات العليا، وهذا ما يركز عليه البحث الحالي وأثره على قرتهم على حل المشكلات الإحصائية. r. تتاولت الدراسات السابقة العلاقات بين متغيرات البحث القدرة على حل المشكلات الإحصائية، ووجهة الضبط، والفاعلية الأتية والتنافز المعرفي بطريقة جزئية بين كل متغير والمتغيرات الأخرى على حده، وقد يؤخذ في الاعتبار متغيرين. ولم تتطرق الدراسات والسابقة إلى بحث العلاقات التفاعلية بين القدرة على حل المشكلات وغيرها من المتغيرات في نموذج سببي واحد، وهو ما يسعى إليه البحث الحالي.

وفي ضوء ما عرض من مصادر الإحساس بالمشكلة، فإن البحث الحالي يـهتم ببحث العلاقات التفاعلية بين القدرة على حل المشكلات الإحصائية، والتنافر المعرفي، وفاعلية الذات البحثية، ووجهة الضبط؛ كي يتحدد النموذج السببي بين هذه المتغيرات. وعليه يمكن بلورة مشكلة البحث في التساويلات (التالية:

ا ـ ما مستوى التتافر المعرفي لاى طلاب الدراسات العليا بكلية التربية جامعة قناة السويس؟ r. ما مستوى فاعلية الذات البحثية لاى طلاب الاراسات العليا بكلية التربية جامعة قناة السويس؟ r. ما وجهة الضبط التي يتنبناها طلاب الدراسات العليا بكلية التربية جامعة قناة السويس؟ ع. هل توجد فروق دالة في القدرة على حل المشكلات الإحصائية لاى طلاب الدراسات العليا بكلية التربية تعزى لإختلاف متغيري المستوى الدراسي (دبلوم خاص، ماجستير، دكتوراه) والتخصص (علم نفس، تريبة خاصة، صحة نفسية)؟ هـ ما النموذج السببي المفسر للعلاقات بين القدرة على حل المشكلات الإحصائية، وأبعاد التنافر المعرفي (الشخصي، والإجتماعي)، وأبعاد فاعلية الذات البحثية (المبادأة والمثابرة، تحمل المسئولية البحثية، الثقة بالنفس)، ووجهة (الضبط؟

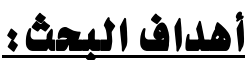

ا - الكشف عن مستوى التنافر المعرفي لدى طلاب الدراسات العليا بكلية التربية جامعة قتاة السويس. 
Y - التعرف على مستوى فاعلية الذات البحثية لاى طلاب الدراسات الطليا بكلية التربية جامعة قناة

$$
\text { السويس. }
$$

r - تحديد وجهة الضبط (داخلي -خارجي) لدى طلاب الدراسات العليا بكلية التربية جامعة قناة

$$
\text { السويس. }
$$

ع - الكثف عن الفروق في القدرة على حل المشكلات الإحصائية لاى طلاب الاراسات العليا بكلية

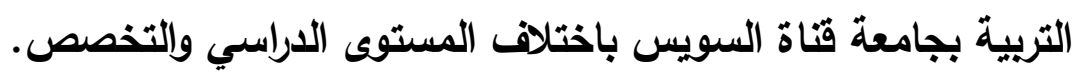
ه - التعرف على أفضل نموذج السببي يفسر العلاقات بين القدرة على حل المشكلات الإحصائية،

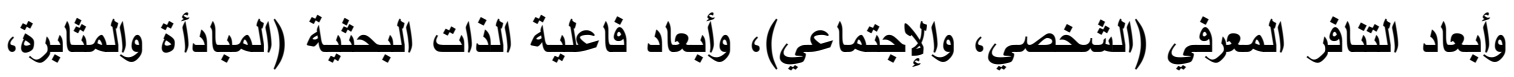
تحمل المسئولية البحثية، الثقة بالنفس)، ووجهة الضبط لاى طلاب الدراسات العليا بكلية التربية جامعة قناة السويس.

\section{أمهية البجث:}

ا. من المتوقع أن تساعد النتائج طلاب الدراسات العليا في تحديد أسباب التنافر المعرفي الذي يشعرون به في مواقف حل المشكلات الإحصائية، وإلعمل على مساعدتهم على التظلب عليها وتقليل تنافرهم المعرفي قبل حل المشكلات. r. كما تتجسد أهمية البحث في ندرة الاراسات العربية التي تتاولت مفهوم "القدرة على حل المشكلات الإحصائية"، على الرغم من أهميته بالنسبة للفرد وخاصة طلاب الدراسات العليا، فالفرد يواجه العديد

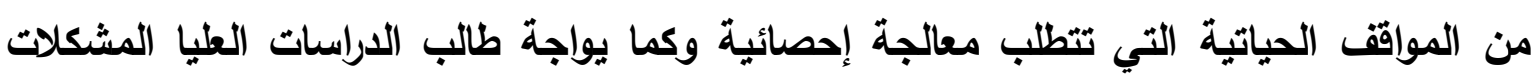
الموقفية التي يجب عليه الإستجابة عليها ليتمكن من تحقيق أهدافه البحثية.

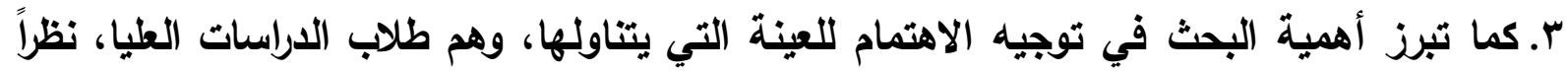

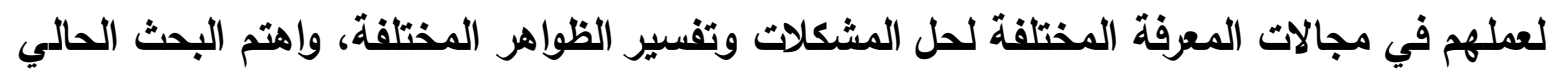
بتتاول قدراتهم على حل المشكلات ويعض المتغيرات التي قد تؤثر على تلك القدرة، في محاولة لتحسين قدرتهم البحثية وكفاءة انتاجية البحوث لايهم.

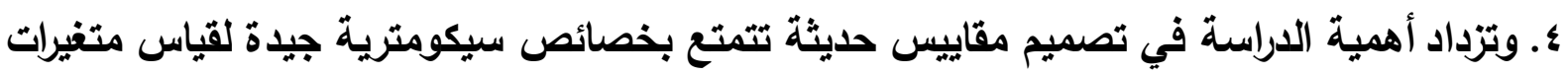
الدراسة (القدرة على حل المشكلات، والتنافر المعرفي، وفاعلية الذات البحثية).

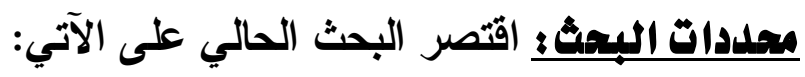

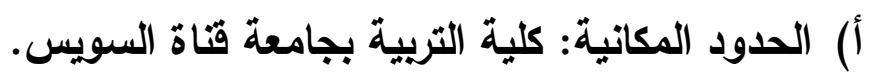

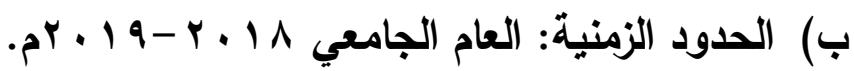

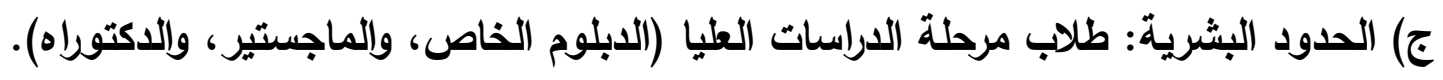
مصطاجمات البجيث: 
ا ـ القدرة على حل المشكلات الإحصائية The Ability to Statistical Problem Solving: تعرفها الباحثة بأنها "القدرة على إجراء بعض العمليات المعرفية عند أداء المهام الإحصائية، والتي تترجم في قرة الفرد على الإحساس بالمشكلة البحثية وتحديدها، وفرض الفروض البحثية لحل هذه المشكلة، وإختيار الأسلوب الإحصائي المناسب للتحقق من تلك الفروض". والتي سيعبر عنها بالدرجات التي يحصل عليها طالب الاراسات العليا على مقياس القدرة على حل المشكلات الإحصائية.

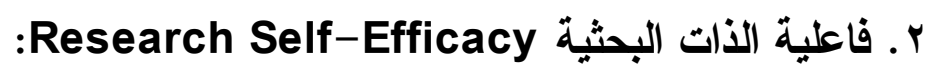

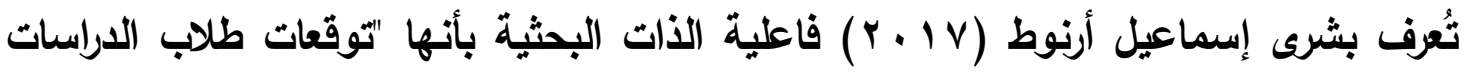
العليا لقدراتهم وإمكاناتهم على أداء المهام والأنشطة المطلوية في مرحلة دراسة الماجستير والدكتوراه؛ سواء توقعهم بالنجاح في المقرات الدراسية، أو قدراتهم على إختيار مشكلة البحث وإعداد مقترح بحثي، وتوقعهم لقدرتهم على عرض المقترح البحثي في السيمينار والرد على التساؤلات الموجهة إليه، وإمكاناتهم على القيام بخطوات البحث العلمي ومراعاة أخلاقياته، وجمع الاطار النظري والدراسات السابقة المرتبطة بموضوع البحث، وإختيار التصميم التجريبي وعينة البحث والأدوات اللازمة والمناسبة، وتوقعهم لقدرتهم على تطبيق الجاتب الميداني من البحث، والتحقى من فروضه، وتفسير نتائجه، وكذلك توقعاتهم لأدائهم في المناقشة العلمية لرسائلهم". وتعرفها الباحثة بأنها "توقعات وتصورات الفرد حول إستعداداته وإمكاناته على إنجاز المهام المرتبطة بمجال البحث العلمي، وتحمله لمسئولية الاستمرار في تنفيذ إجراعات البحث على أكمل وجه، وتوقعاته عن كيفية مواجهة الصعويات، والتخطيط والمثابرة لإنجاز البحث العلمي في موعده". وتضم الأبعاد التالية: (أ) المبادأة والمثابرة: قدرة الباحث على تحقيق أهداف محددة مسبقاً، والتتبؤ بالصعويات والمشكلات قبل وقوعها، وقدرته على إتخاذ القرار المناسب لمواجهة تلك الصعويات. (ب) تحمل المسئولية البحثية: قدرة الباحث على الاحساس بمسئوليته تجاه إنجاز الأعمال التي يكلف بها. وإلتزامه بأدائها على الوجه الأمثل في الموعد المحدد. (ج) الثقة بالنفس: شعور الباحث بالثقة في قدراته وامكاناته الأكاديمية والبحثية، وقدرته على توظيف معارفه في المواقف المختلفة. r. التنافر المعرفي Cognitive Dissonance: تُعرفه الباحثة بأنه "الشعور بعدم الرضا والارتياح، نتيجة لتعارض ما يقوم به من سلوكيات وأفكار وأراء وإتجاهات مع نسقه المعرفي، ويترتب عليها حالة من التوتر والقلث؛ ويسعى القرد جاهداً لإزالة هذا التعارض حتى يصل لحالة التوازن". ويتضمن الأبعاد التالية: 
(أ) البعد الثخصي: حالة الصراع الداخلي التي يعاني منها الفرد عند أداعه لسلوكيات أو تبنيه لأفكار

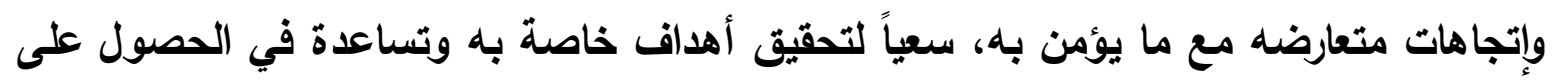

$$
\text { منافع شخصية. }
$$

(ب) البعد الإجتماعي: حالة من الضيق والإنزعاج التي يعاني منها الفرد عندما يضطر لتغيير آراؤه وإتجاهاته وأفكاره نحو موقف معين مسايرةً لسلوك الجماعة، أو تعاطفاً ومساعدةً للأخرين ودريء

$$
\text { الضرر عندهم. }
$$

ع. وجهة الضبط Locus of Control

عرف روتر Rotter (47 (97) وجهة الضبط بأنه الطريقة التي يدرك بها الفرد مصدر التدعيمات الإيجابية والسلبية التى تحدث له ترتبط بعوامل داخلية شخصية (مثل الذكاء، والمهارة والكفاءة، وسمات الشخصية)، أو عوامل خارجية (مثل الحظ، والقدر، وتأثير الآخرين، أو لعوامل غير فئه

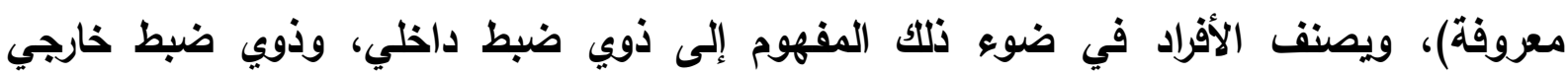

.(Konan, 2013)

\section{الغلفية النظرية واللدراسات السابقة:}

( (1) القدرة على حل المشكلات الإحصائية The Ability to Statistical Problem Solving: تعد قرة الأفراد على حل المشكلات، أحد العوامل الحاسمة للنجاح الشخصي، وهى على علية

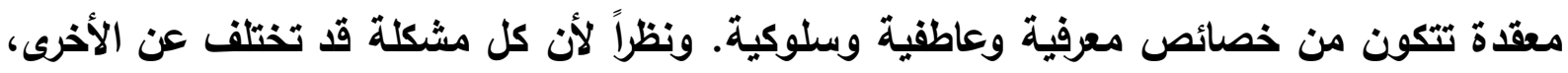

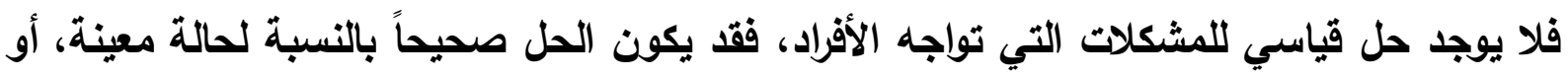

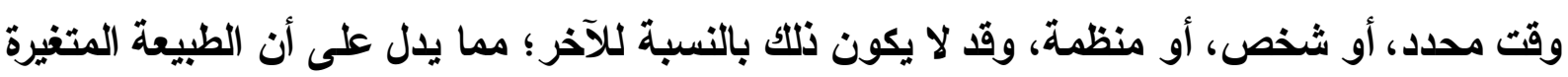

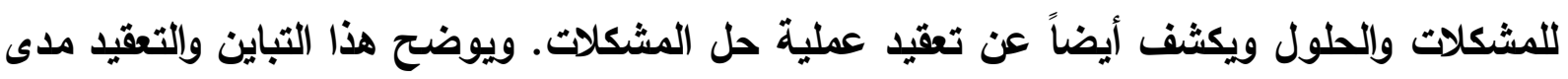

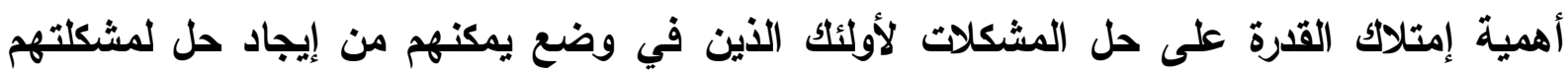
.(Konan, 2013)

ويستخدم تعبير حل المشكلات في مجال علم النفس المعرفي معبراً عن السلوكيات والعمليات الفكرية الموجهة لأداء مهمة ذات منطلبات عقلية معرفية. ويعتبر حل المشكلات من الأنشطة العقلية

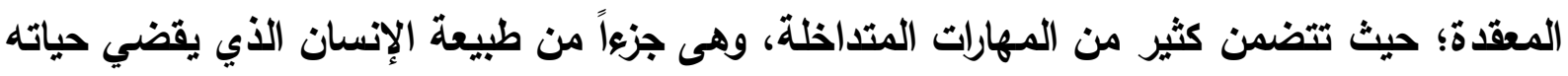

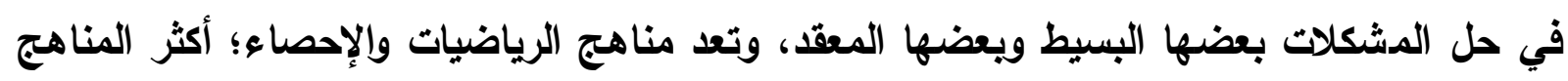

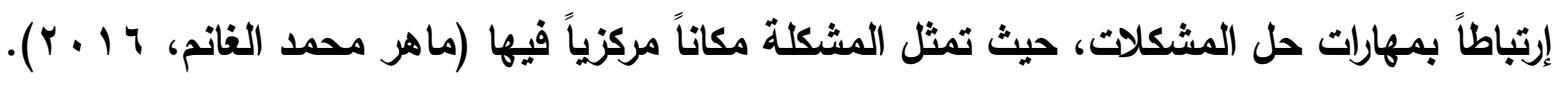

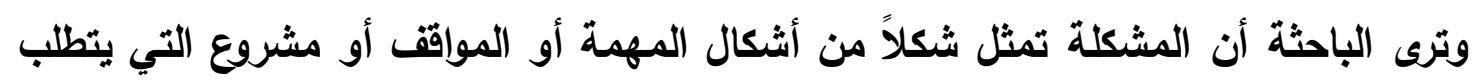

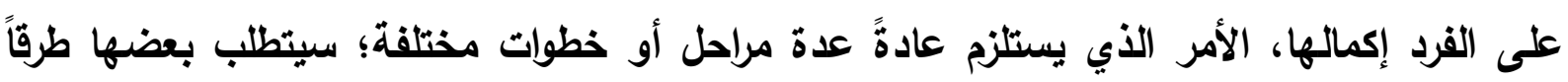


محددة مرتبطة بمجال المشكلة أو تخصص الفرد، وحل المشكلة هو الإستجابة السلوكية المعرفية والموجهة ذاتياً.

وفيما يتطلق بالقدرة على حل المشكلات، فيعرفها عادل محمد العدل ( 1 ( . ب) بأنها قرة الفرد

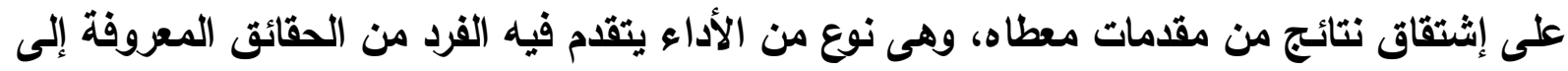
الحقائق المجهولة المراد الوصول إليها، عن طريق فهم وإدراك الأسباب وراء المشكلات التي يقوم

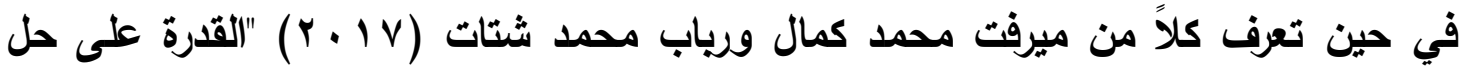

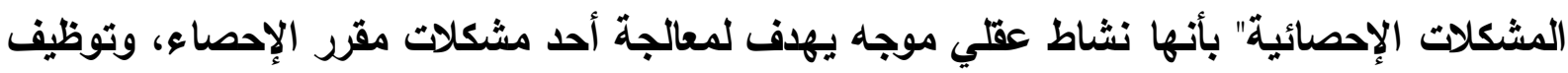
الطالب ما إكتسبه من معرفة وخبرات رياضية لإجراء المعالجات المعرفية وفوق المعرفية، ويتوظيف

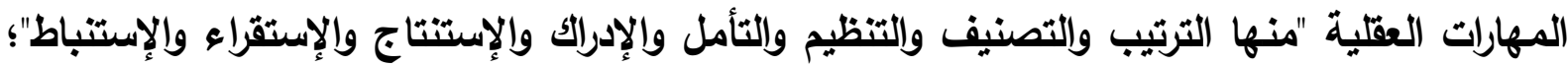

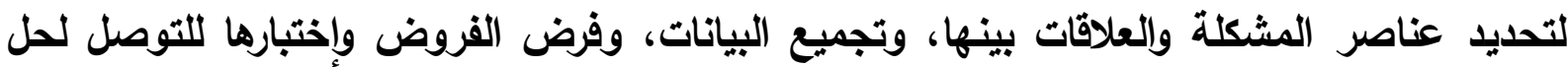
أنسب، وتقييمها ثم تعميمها في مشكلات متشابهة.

ويميز دزيلا D'zurilla بين القدرة على حل المشكلات وسلوك حل المشكلات، مشيراً إلى أن

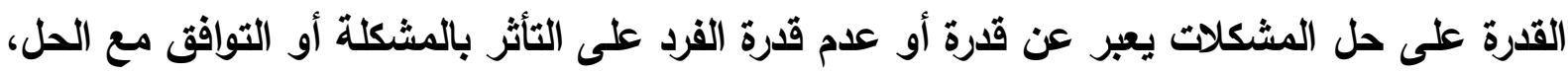

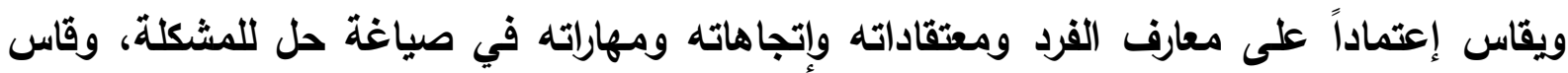

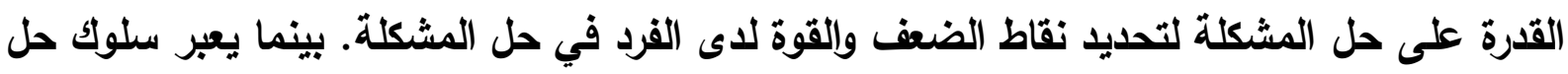
المشكلات عن ناتج عملية حل المشكلة، ويقاس من خلال تقريراً ذاتياً أو ملاحظة الفرد أثناء القيام بحل المشكلة، ويقاس سلوك حل المشكلة للتحقق من صدق نماذج حل عل المشكلات أو نتائج برامج

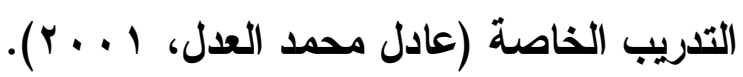

وتعددت الإتجاهات والنظريات المفسرة للقدرة على حل المشكلات؛ فيعتمد حل المشكلة في

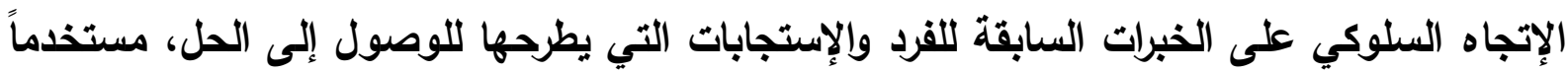

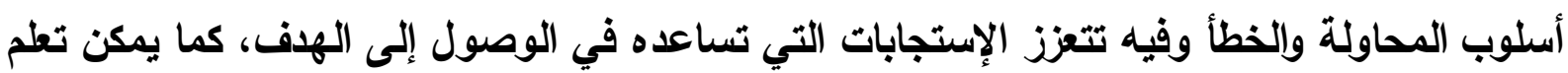

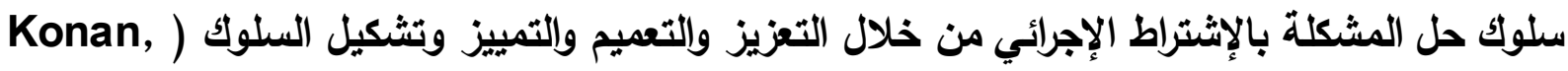

ويرى أصحاب النظرية المعرفية أن إستجابة القرد في مواقف حل المشكلات تعتمد على قيامه بعمليات معرفية عليا تتضمن الإستبصار والتفكير بجميع أثكاله، وتتم عملية حل المشكلة من خلال

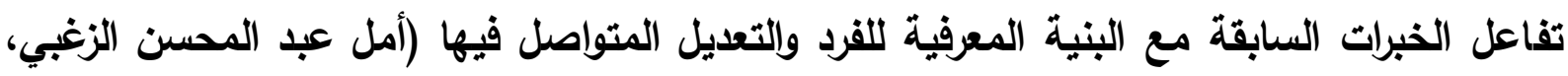


بينما يرى إتجاه تجهيز المعلومات أن نشاط حل المشكلة هو نشاط وقتي يرتبط بالموقف المشكل ويستخدم فيه الفرد المعلومات المخزنة في الذاكرة ويجري عليها بعض العمليات المعرفية لمعالجة المطلومات المتاحة وصولاً للحل، فيستقبل النظام المعرفي للفرد المثيرات والمعلومات المدخلة فئلة والتي تمثل معطيات المشكلة وعناصرها والطرق والأساليب المتاحة لها، ويقوم الفرد بمعالجة تلكي المعومات من خلال عمليات معرفية مثل التذكر والتفكير والإدراك والتفكير وتتم المعالجة بمستويات مختلفة تتراوح بين المستوى السطحي والمركب أو العميق، وصولاً للمخرجات التي تمثل حلاً مناسباً

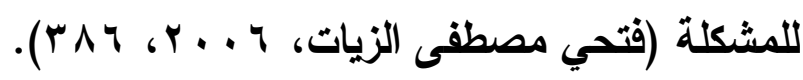

وأقترح سنتيرنبرغ Sternberg دورة لحل المشكلات أطلق عليها "حلقة التفكير" تقوم على افتراض أن التفكير الصحيح أثناء حل المشكلات ليس تفكيراً خطياً يسير في إتجاه واحد؛ بل تلفئ تفكير

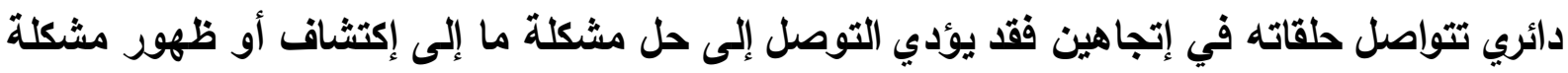

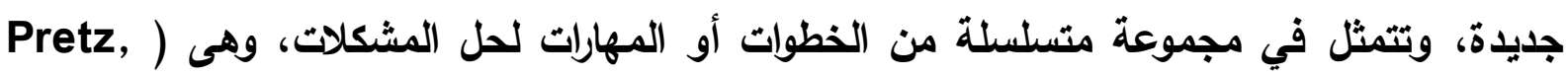
:(Naples \& Sternberg, 2003, 3 ا. التعرف إلى وجود مشكلة، وفيها يدرك الفرد الصعويات التي تقف أمامه عند تحقيق أهدافهم، وفيها يشعر طالب الاراسات الطيا بوجود مشكلة تتمثل في تناقض نتائج الداسات السابقة أو ثغرة بحثية

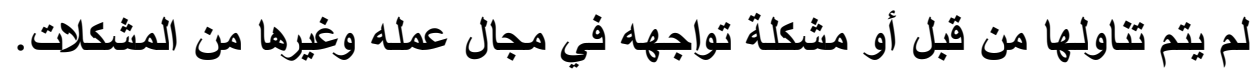

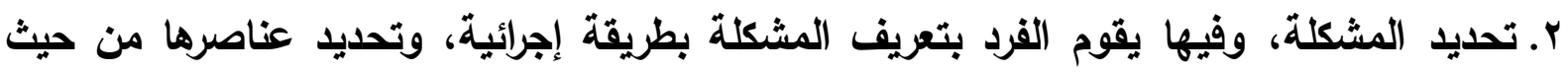
الأهداف وطرق الحل، ودراسة أسباب وعوامل المشكلة.

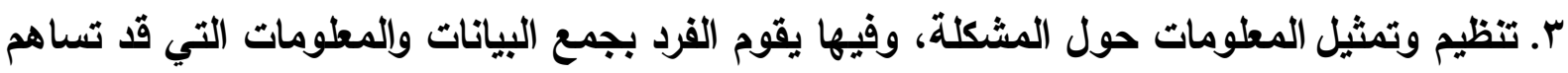

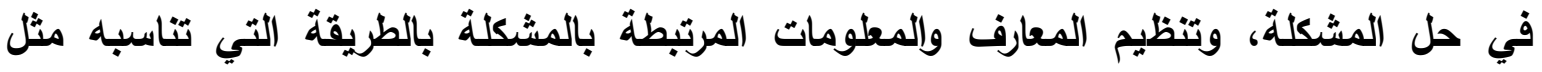

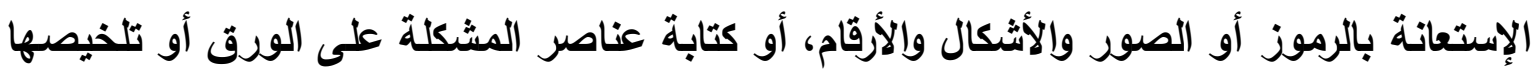

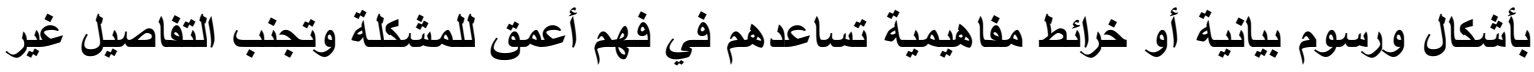
ذات العلاقة بالمشكلة.

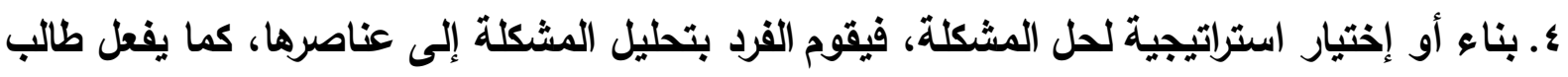

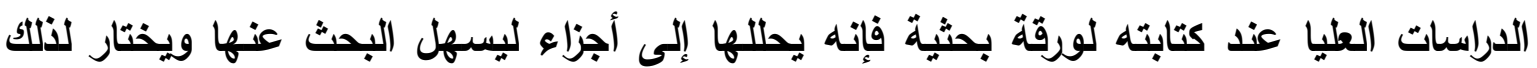
الطريقة التي يفضلها من مصادر جمع البيانات وتنظيمها. ه.تخصيص المصادر لحل المشكلة، وتعدد المصادر التي تساعد الفرد في حل المشكلة ومن أهمها تنظيم الوقت بفعالية، ويذل جهاً قبل طب مساعدة الأخرين، وتوفير المال والأدوات اللازمة ومكان الوصول إليها. 
7. مراقبة حل المشكلة، وفي هذه الخطوة يقوم الفرد بمراقبة عملية الحل، وعمل تقويم ذاتي مستمر للتأكد من مدى إقترابه من هدفه، وكذلك العمل على إزالة العقبات عند ظهورها، فعلى سبيل المثال يقوم طالب الدراسات العليا في هذه الخطوة بمتابعة عملية تقدمه في تنفيذ خطة بحثه وتحديد العقبات والأسباب المعيقة ويعد مخططاً جديد للتظلب على تلك العقبات.

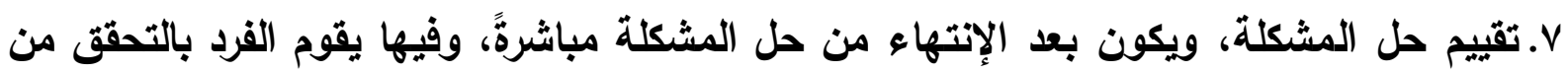

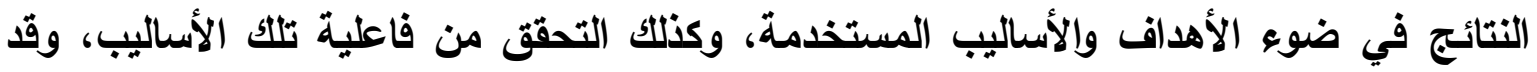
يدرك الفرد في نهاية الحل مشكلات جديدة ومصادر جديدة للمعلومات. وفيما يتعلق بخطوات ومهارات حل المشكلة الإحصائية، إتفق الباحثين ( Marriott, Davies Gibson, 2009; Jones \& Jacobbe, 2014 تتمثل في أربعة خطوات رئيسية وهى: الشعور بالمشكلة وتحديد عناصرها، وجمع البيانات، ومعالجة وتحليل تلك البيانات، ومناقشة النتائج وتفسيرها.

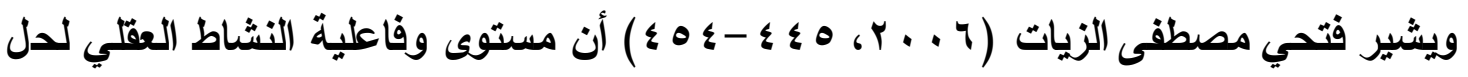

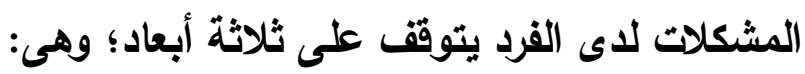

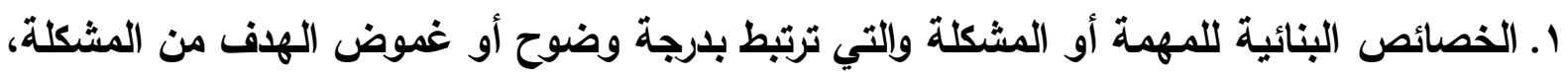
ودرجة تعقيد أو بساطة المشكلة، ووجود حل واحد أو حلول متعددة للمشكلة، وكون الحل معتمداً على الإستدعاء أو على إنتاج الفرد لأفكاراً إبداعية.

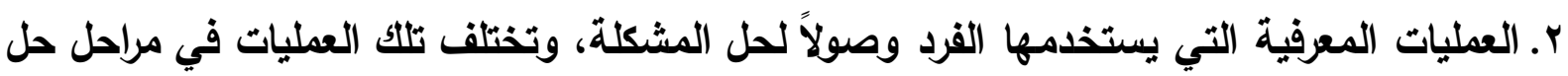

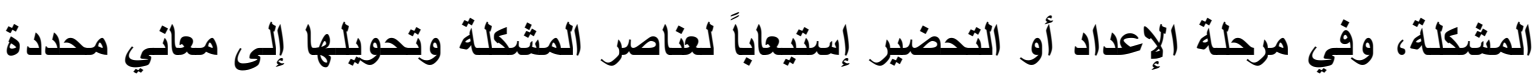

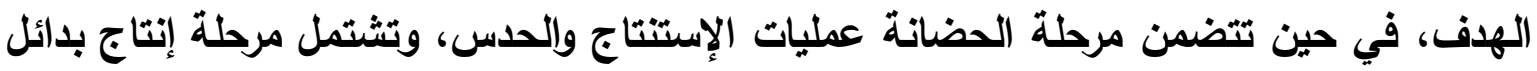
الحول يستخدم الفرد بعض العمليات التحليلية لكل من الوسائل والغايات وعمليات الإتتاج التقاريي والتباعدي للأفكار التي تحقق الهدف، بينما تتضمن مرحلة التقويم بعض العمليات مثل المقارنة

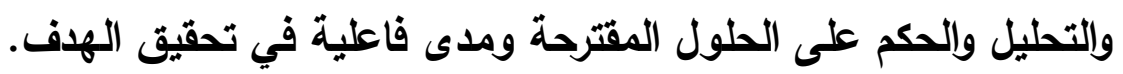

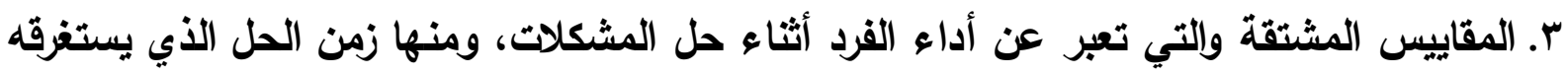
الفرد للوصول إلى تحقيق الهذف ويقوم على إفتراض أن سرعة حل المشكلة يرتبط مباشرة بقدرة

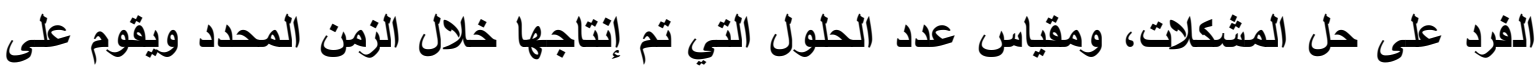

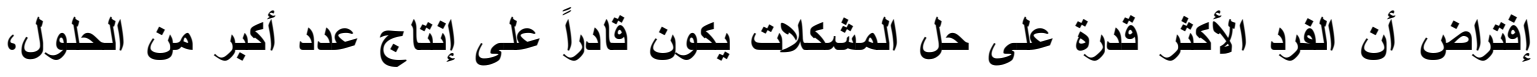

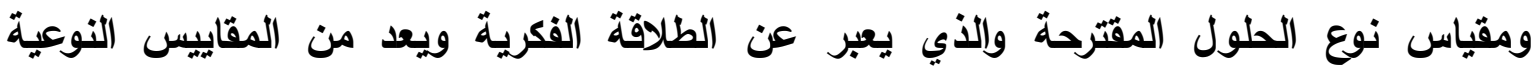

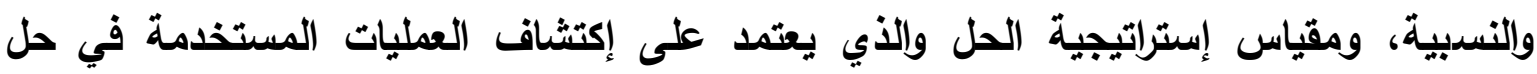

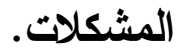




\section{:Cognitive Dissonance التنافر المعرفي (r)}

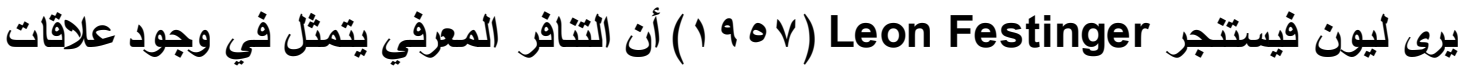
غير منسجمة بين المعارف، ويعتبر ذلك عاملاً دافعاً في ذاته، ويقصد بالمعارف أي معرفة، أو رأي، أو معثقد حول البيئة، أو حول سلوك الفرد. ويعتبر حالة سابقة تقود إلى نشاط موجه يعمل على تخفيض التنافر (Miklosovic, 2010؛ سميرة محارب العتيبي، 10 م ب). وتفترض نظرية التنافر المعرفي فيستنج Festinger وجود علاقة متوازنة بين المعرفة والسلولك، وتقوم على إفتراض أساسي وهو أن الفرد يسعى للحفاظ على توازن نظامه المعرفي الذي يتكون من مجموعة معقدة ومتداخلة من المعتقدات، والإتجاهات، والقيم التي تؤثز في السلوك ونتأثز بها، وينزعج الفرد عندما يواجه تناقضاً في نظامه المعرفي؛ فتتولا حالة من التتافر السلبي، تتمثل في وجود علاقات غير منسجمة أو متوافقة بين معارفه أو سلوكياته أو أفكاره أو آرائه ومعتقداته أو إتجاهاته، وتمثل تلك الحالة ذاتها دافعاً للعمل على خفض التافر المعرفي، مثلما يقود الجوع إلى نشاط

موجه نحو تخفيض الجوع (Randles, Inzlicht, Proulx, Tullett \& Heine, 2015. وأوضح دانيال Daniel أن الفرد يمكن أن يواجه التتافر المعرفي بعدة طرق منها؛ تغيير معتقد

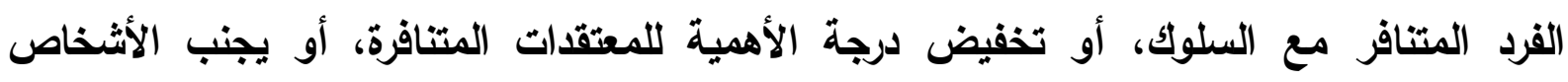
والمواقف التي تحدث التنافر، أو إيجاد مزيد من الدعم من الأفراد الأين لايهم معتقدات مماثلة لتأكيا Miklosovic, ) وتثيث تثلك المعتقدات، أو تغيير السلوت نفسه، ورفض ومقاومة مصدر التنافر

$$
\text { 2010؛ مريم حميد اللحياني، و } 1 \text { • ب). }
$$

ويشير كل من ليتيلجون وفوس Littlejohn \& Foss إلى أن درجة التنافر تعد دالة لعاملين؛ هما: مدى الإتساق بين العناصر المتناغمة والمتنافرة، وأهمية تلأك العناصر أو الموضوع

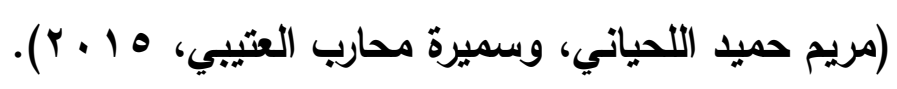

وتعددت الدراسات التي تحرث حجم التنافر المعرفي لاى طلاب الجامعة، ومنها دراسة مريم

حميد اللحياني (0 1 • r) التي توصلت إلى أن حجم التتافر المعرفي لاى طلاب وطالبات جامعة أم

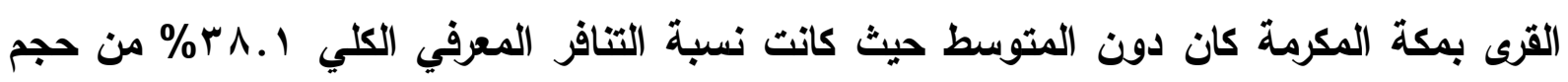
العينة الكلي، وأن أكثر أبعاد التتافر المعرفي حجماً وإنتشاراً هو البعد الإجتماعي (الخارجي) يليه التتافر الشخصي (الداخلي). كما أظهرث النتائج وجود فروق دالة إحصائياً في درجة التنافر الداخلي لدى عينة الدراسة لصالح الطالبات، في حين لا توجد فروق بين الطلاب والطالبات في درجة التنافر المعرفي الخارجي.

ودراسة عمر عطا الله العظامات، وعدنان يوسف العتوم (1 ا • r) التي أشارت إلى أن مستوى التنافر المعرفي لاى طلبة جامعة اليرموك بالأردن متوسطاً، ومستوى التنافر على جميع أبعاد المقياس 


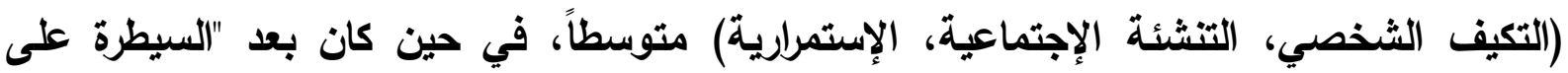

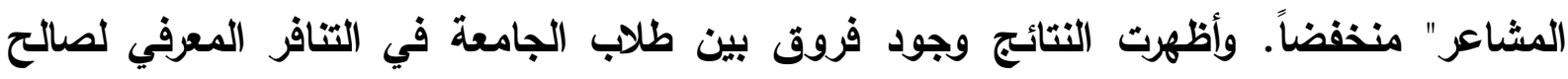

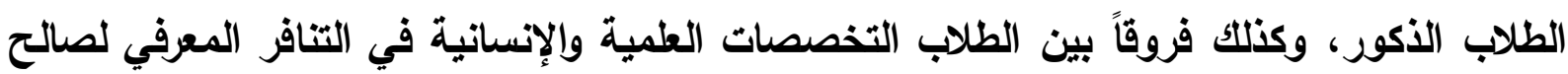
الكليات العلمية. وفيما يتعلق بالدراسات التي ريطت بين القدرة على حل المشكلات والتنافر المعرفي، أجرى ويسنيارتي وسوجيمان (Wisniarti \& Sugiman, 2018) دراسة وصفية للتحقى من التنافر بافن المعرفي الذي يعاني منه الطلاب أثناء حل المشكلات غير الروتينية، وطبقت الدراسة على الهى طالبة متوسطة التحصيل الرياضي في الصف الثاني في المدارس الثانوية تخصص العلوم الطبيعية في يوجياكرتا. وتم جمع البيانات في هذه الدراسة من خلال إختبار كتابي وإجراء مقابلة مع الطالبة، وكان الإختبار المعطى يتطلب حل ثلاث مشكلات غير روتينية حول تحديد محيط الطائرة، ويعد إجراء الإختبار تم فحص ورقة إجابة الطالبة لمعرفة تسلسل إجراءات حل المشكلات غير فير الروتينية، كما أجريت مقابلة

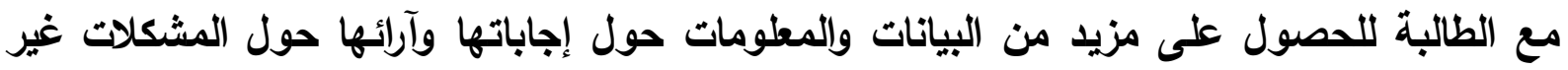

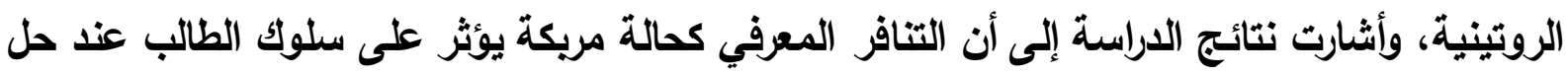

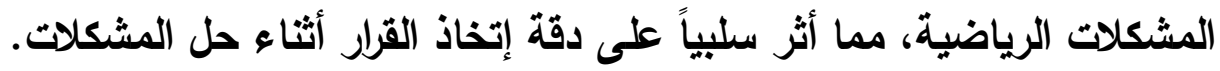

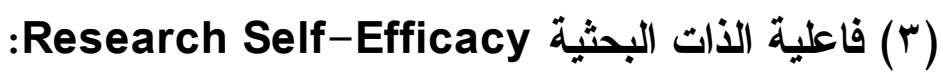
عرف ألبرت باندورا ( 9 VV) Albert Bandura فاعلية الذات بأنها "مجموعة الأحكام الصادرة عن الفرد، والتي تعبر عن معتقداته عن قدراته على القيام بسلوكيات معينة، ومرونته في

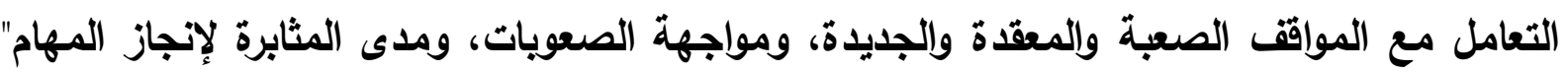
.(Bandura, 2006)

ويرى عادل محمد العدل ( 1 . . r) أن فاعلية الذات تثثير إلى ثقة الفرد الكامنة في قدراته خلال

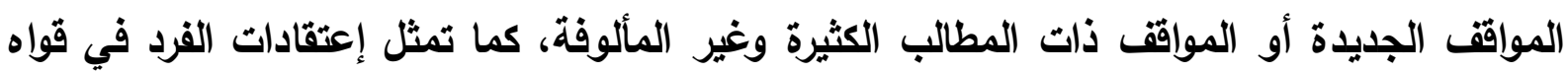
الثخصية، مع التركيز على الكفاعة في تفسير السلوك.

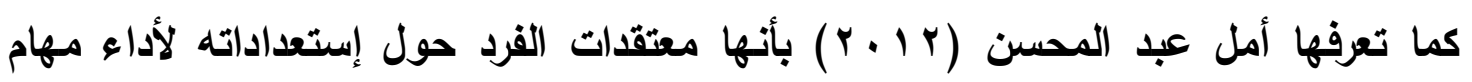

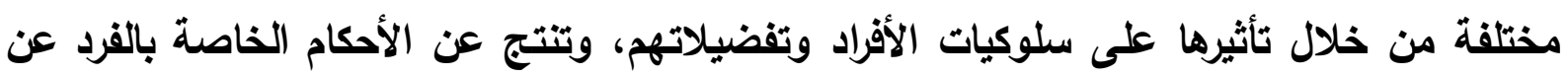
قدرته على تنظيم وتطبيق المهارات والمعارف الضرورية في مواجهة المهام الحياتية المختلفة. بينما

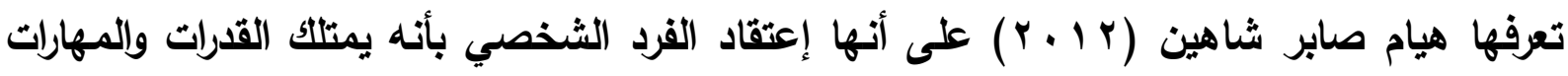

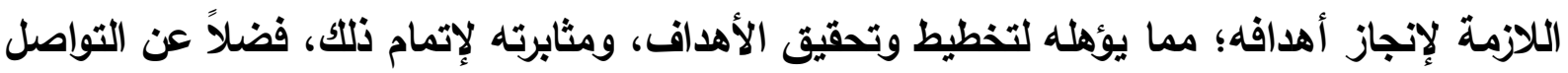

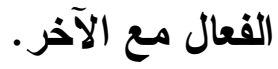


ويعرفه كل من جيفمان ورابان (Geifman, \& Raban, 2015) بأنه معتقدات القرد حول

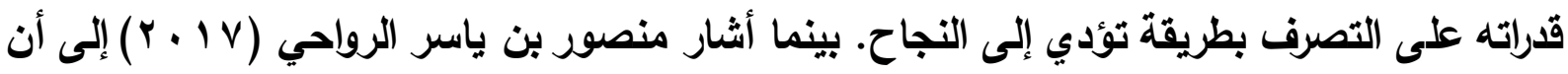
فاعلية الذات في تعلم الإحصاء هى "تصور الطلاب عن قدراتهم المتعقلة بتتفيذ مهمة معينة لإنجاز أ أهداف محددة.

ويستتد مفهوم فاعلية الذات إلى النظرية المعرفية الإجتماعية لباندورا (Bandura, 1994)؛ الذي إفترض أن المتعلم يحتاج إلى مجموعة عوامل متفاعلة (الشخصية، والسلوكية، والبيئية) لتكوين تصوراً متكاملاً عن ذاته، وتحدد العوامل الشخصية معتقدات الفرد حول معارفه وقدراته وإتجاهاته "فاعلية الذات"، وتتضمن العوامل السلوكية مجموعة إستجابات الفرد في موقف محدد "الأداء"، وتعبر

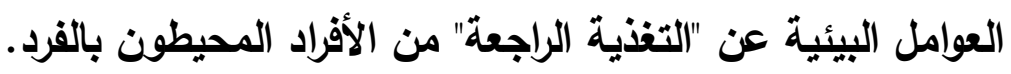
كما أوضح باندورا (Bandura, 2006) أنه يمكن قياس فاعلية الذات إعتماداً على ثلاث

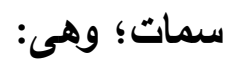
1. مستوى الفعالية Magnitude: ويشير إلى مستوى القوة الدافعة للفرد للأداء في المواقف

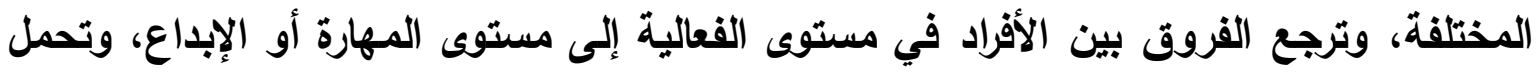
الضغوط، ومستوى الدقة والإتتاجية، أو هى درجة صعوية التي يشعر بها الفرد عند أدائه المواقف القف أو المهام. r. العمومية Generality: ويعبر عن انتقال توقعات الفعالية إلى مواقف مشابهة، أي مجموعة

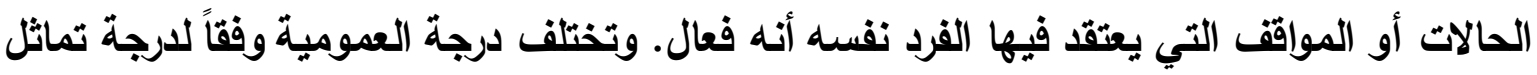
المهام، وطريقة التعبير عنها سواء سلوكية أو معرفية أو وجدانية، وخصائص الموقف أو المهمة، ونها، وخصائص الفرد نفسه. r. القوة أو الثدة Strength: ويعني درجة ثقة الفرد في تقديرات أدائه، أي شدة أو ضعف إعتقاد

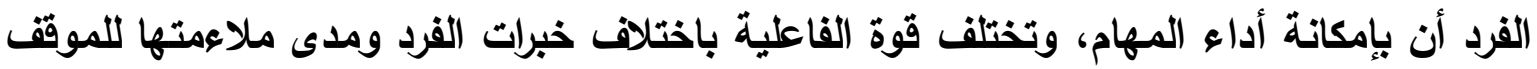
أو المهمة. فالفرد الذي يمتلك توقعات عالية عن قدرته على أداء المهمة يمكنه المثابرة ويذل الجهاء لإتمام تلك المهمة. وحدد ألبرت باندور (Bandura, 2009) أريعة مصادر للفعالية الذاتية؛ حيث أشار إلى أنه تكتسب فاعلية الذات وتضعف وتتمى من خلال عاملاً واحداً أو أكثر من العوامل التالية:

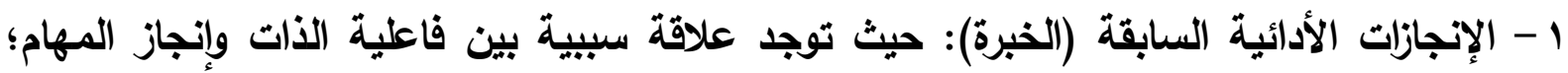

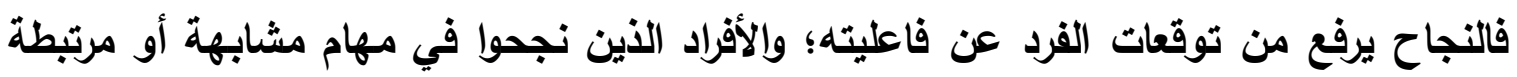

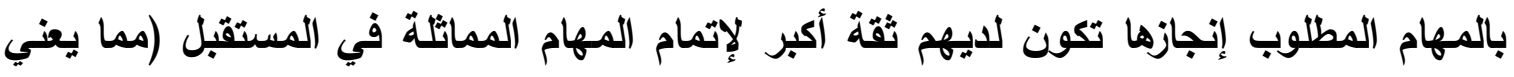

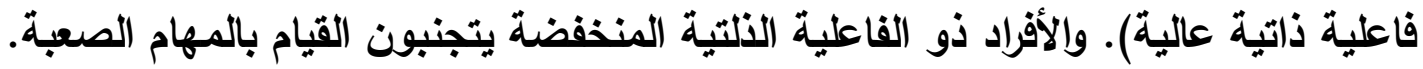


ץ - والخبرة البديلة (النمذجة): من خلال الإستقادة من تجارب الآخرين، ويطلق عليه التعلم بالنموذج وملاحظة الآخرين؛ فالأفراد الذين يلاحظون نماذج ناجحة يطبقون تلك الملاحظات في أدائهم للمهام وفي تقدير فاعليتهم الخاصة. r- والإقناع اللفظي (التشجيع): ويقصد بها المطلومات اللفظية التي تأتي للفرد من الآخرين وإقتناع الفرد بها، مما يدفعه ويرغبه في الأداء أو الإنجاز. كما يشير إلى التحفيز الإجتماعي الذي يمارسه المحيطون بالفرد لإقتاع المتعلم لفظياً بقدرته على التجاح في أداء المهام. ع - والحالة الفسيولوجية والنفسية: وتثير إلى مجموعة العوامل التي تحدد مدى قدرة الفرد على تحقيق أهدافه، ومن تلك العوامل القلق وقوة الإنفعال؛ فالأفراد ذو مستوى القلق المرتفع تكون لايهم تصورات ذاتية منخفضة عن فعاليتهم، بينما الأفراد ذوي مستوى القلق الطبيعي تزداد توقعاتهم عن فعالية الذات.

ويتسم الأفراد ذوي الثقة في قدراتهم بالثبات في تحقيق الأهداف، ومواصلة بذل الجها والإصرار على مواجهة الصعويات، ودعم ذاته وإعادة المحاولات بعد التجارب الفاشلة في تحقيق الأهداف، بينما يتصف أصحاب الفعالية الأتية المنخفضة بعدم الإلتزام بتفيذ المهام التي يرونها صعبة، ويفشلون في Forester, Kahn, \& Hesson-Mclnnis, ) بذل الجهد، ويميلون إلى تجنب تلك المهام

ويسهم المستوى العالي من الفاعلية الذاتية المدركة في التتبؤ بنجاح الفرد ويسهم في تحسين أدائه الأكاديمي؛ وكلما زادت الفعالية الأتية للفرد، زاد جهده ومقاومته وصبره على إتمام المهام Forester, Kahn, \& Hesson-McInnis, 2004; ) الأكاديمية حتى إنجاز ويلوغ الأهدافي" .(Tella, Ayeni, \& Omba, 2007 ووفقاً لباجاريس Pajares فإن الفاعلية الأتية للفرد لا تتعلق بقدراته الفطية، بل بالأحرى ترتبط بمعتقداته بما يمكنه تحقيقه، ويالتالي فهى عامل محوري للنجاح من خلال التحفيز الأتي، فلن يكون القرد قادراً على القيام بمهمة معينة لايه القدرة عليها؛ إلا إذا كانت لايه الثقة بقدراته على القيام بهنا (Büköztürk, Atalay, Sozgun, \& Kebapçı, 2011) كما أوضتح باندورا (Bandura, 2009) أن معتقدات الفرد عن فعاليته تساهم بشكل كبير على أهداف الفرد ومستوى الجها والمثابرة لايه تعلم المهام الصعبة؛ فنادراً ما يستمر الفرد في أداء مهام يتوقع عدم نجاحه في اجتيازها، وتؤثر الفاعلية الذاتية على التعم والأداء بثّلاث طرق؛ هى: 
ا.تتؤثر الفاعلية الذاتية على الأهداف التي يختارها الأفراد لأنفسهم، فيميل الفرد ذو الفاعلية الذاتية

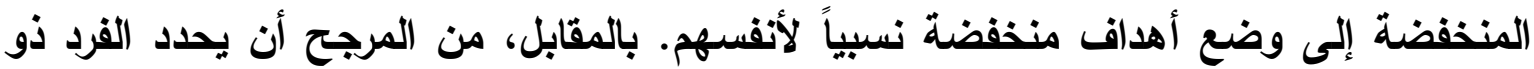
الفاعلية الذاتية العالية أهدافًا شخصية عالية. r. وتؤثر الفاعلية الذاتية في مستوى التعلم والجها المبذول، فيعمل الفرد ذو الفاعلية الذاتية العالية

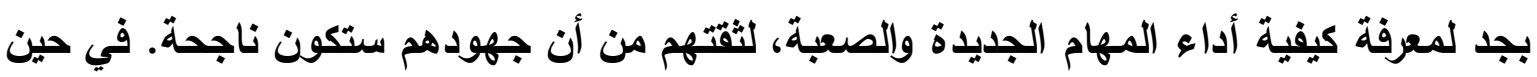

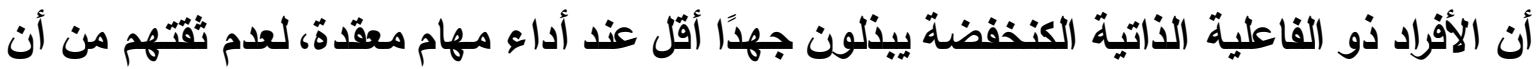

$$
\text { الجهذ سيؤدي إلى النجاح. }
$$

r. كما تؤثر الفاعلية الذاتية على المثابرة التي يحاول بها الأفراد القيام بمهام جديدة وصعبة، فالأفراد ذو الفاعلية الذاتية العالية واثقون من أنهم قادرون على تعلم وتنفيذ مهمة محددة حتى وإن

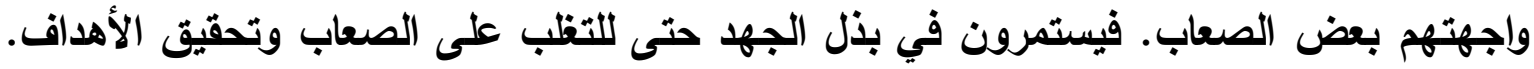

على العكس من ذلك، يستسلم الأفراد ذو الفاعلية الذاتية المنخفضة فئة عندما تواجههم المشكلات. وخلص باتدورا Bandura إلى أن فاعلية الذات ليست عامة ولكنها محددة، حيث يرتبط

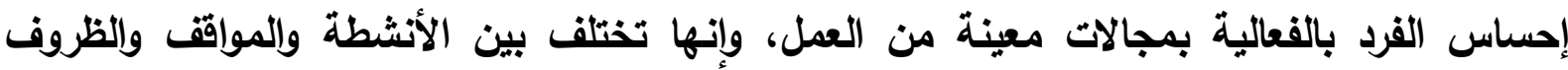

.(Brancolini \& Kennedy, 2017)

Phillips \& Russell, 1994; Bieschke, Bishop \& ) وأكلات بعض الدراسات Brancolini \& ؛Garcia, 1996; Forester, Kahn, \& Hesson-McInnis, 2004 Kennedy, 2017

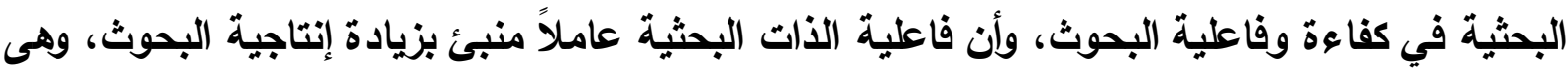
تعبر عن معتقدات طلاب الماجستير والدكتوراه حول قدرتهم على أداء المهام البحثية لإنتاج أبحاثاً قيمة.

وفيما يتطق بالداسات العربية التي تقصت مستوى فاعلية الذات لدى طلاب الجامعة، أظهرت

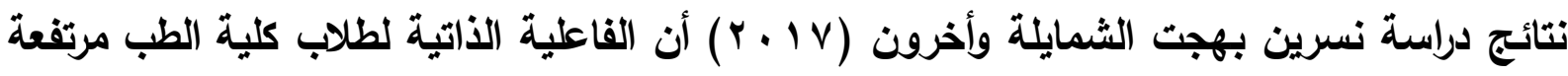
في كل الفرق الاراسية وفي كلا الجنسين، وعدم وجود فروق في درجات الفاعلية الذاتية بين الطلبة

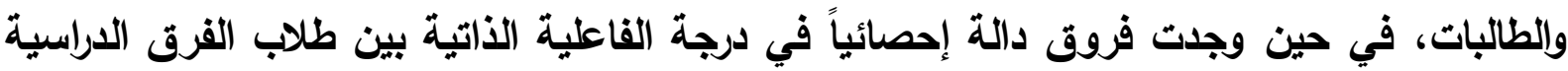
لصالح طلاب الفرقة الخامسة.

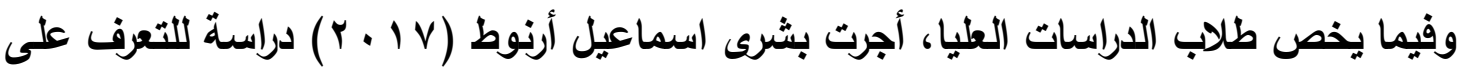

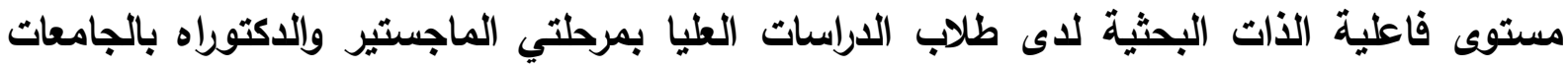

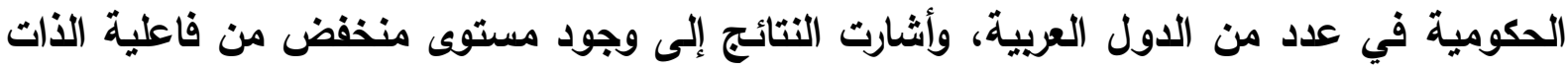
البحثية لاى الطلاب في الارجة الكلية للمقياس وفي الأبعاد الفرعية (توقع النجاح في إختيار المشكلة، 
توقع النجاح في عرض المقترح البحثي، القدرة على جمع الأدبيات النظرية، فاعلية إختيار التصميم المنهجي، توقع القدرة على عرض النتائج ومناقشتها)، بينما وجدت مستوى متوسط في بعدين (توقع النجاح في المقررات، وكفاءة جمع البيانات). كما وجدث فروق في متوسطات درجات أبعاد فاعلية الأات البحثية (توقع النجاح في إختيار المشكلة، توقع النجاح في عرض المقترح البحثي، توقع القدرة على عرض النتائج ومناقشتها) بين الطلاب بإختلاف النوع لصالح الطلاب الأكور. كما وجدت فروق دالة بين متوسطات درجات أبعاد فاعلية الذات البحثية (توقع النجاح في المقررات، توقع النجاح في إختيار المشكلة، القدرة على جمع الأدبيات النظرية، وكفاءة جمع البيانات، توقع القدرة على عرض النتائج ومناقشتها) بإختلاف المرحلة الدراسية لصالح طلاب الدكتوراه. ومن زاوية أخرى تناولت بعض الاراسات فاعلية الأتية والقدرة على حل المشكلات، ومنها دراسة بوفورد بوشارد (Bouffard-Bouchard, 1990) التي هدفت إلى دراسة تأثير أحكام فاعلية الذات على الأداء المعرفي لاى عينة مكونة من ؛ ج طالب جامعي كندي ذوي معارف وخبرات متعادلة في مجال الأداء. وأظهرت النتائج أن الإختلافات في تصورات فعالية الذات المدركة كانت مرتبطة بعدد المشكلات التي ينجزها الفرد، وكفاءة إستراتيجيات حل المشكلات، ودقة التقييم الأتي لـإستجابات.

وأشار باجاريس (Pajares, 1996) إلى إرتباط فاعلية الأت بمهارات حل المشكلات، حيث يميل الأفراد ذوي فاعلية الذات المرتفعة إلى التصدي للمشكلة والشعور بالثقة في قدرته على مواجهتها وفاعلية الطرق والأساليب التي يستخدمها في حلها. في حين أن الأقراد ذوي فاعلية الذات المنخفضة يميلون إلى إدراك الموقف على أنه يمثل تهديداً لذاتهم مما يدفعهم إلى الإحجام عن حل المشكلات.

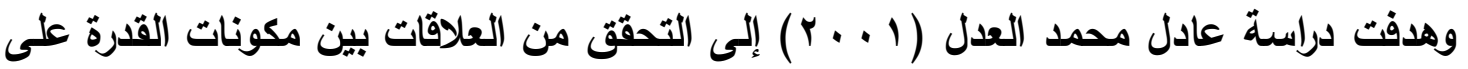
حل المشكلات الإجتماعية وكل من فاعلية الأت والإتجاه نحو المخاطرة، لدى عينة من 1 V طالباً مصرياً بكلية التربية بالزقازيق، ويإستخدام تحليل المسار أشارت التتائج إلى وجود علاقة موجبة بين فاعلية الأت والقدرة على حل المشكلات الإجتماعية ومكوناتها (توجه المشكلة، ومهارات حل المشكلة). كما أنه أمكن التنبؤ بلرجات الطلاب على مقياس القدرة على حل المشكلات الإجتماعية من خلال درجاتهم على مقياس فاعلية الذات. كما قام هوفمان (Hoffman, 2006) ببحث أثز كل من فاعلية الذات والذاكرة العاملة ودرجة تعقيد المشكلات في الأداء على حل المشكلات الرياضية وزمن الإستجابة والكفاءة (أي النسبة بين زمن الإستجابة وعدد المشكلات التي تم حلها بشكل صحيح)، وإستجاب الطلاب على مهمة إعادة ترميز الحروف أو مهمة مدى العملية، ثم قاموا بتقييم كفاعتهم الأتية لحل مشكلات الضرب العقلي، ثم 
حلوا مشكلات مماثلة ذات تعقيد متفاوت. وأوضحت النتائج تأثير كبير للفاعلية الذاتية على الأداء والكفاءة في حل المشكلات.

وإختبرت دراسة بتلر (Butler, 2008) العلاقة بين فاعلية الذات وأداءالطلاب على حل

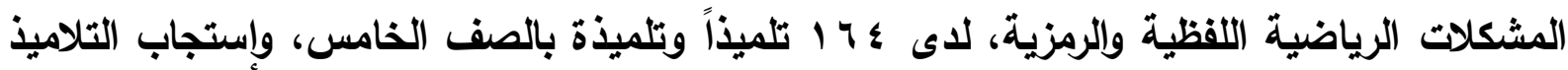

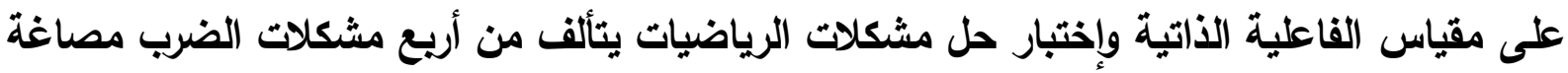

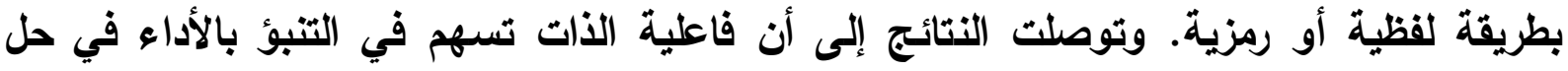
المشكلات الرياضية.

Zheng, McAlack, ) ويحثث دراسة كل من زهنج وماك -آلاكك ويلميس وإفانس وويليامسون (Wilmes, Evans, \& Williamson, 2009

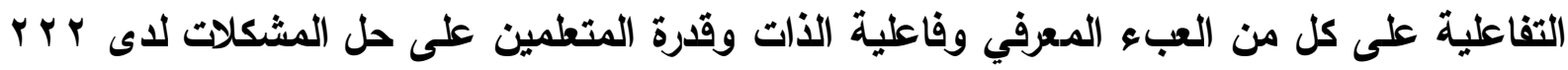

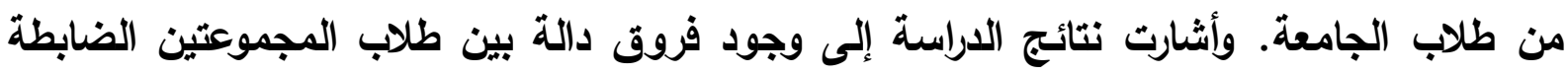
والتجريبية في فاعلية الذات والقدرة على حل المشكلات لصالح طلاب المجموعة التجريبية، كما أظهرت النتائج وجود علاقة إرتباطية موجبة بين فاعلية الذات وحل المشكلات لاى جميع الطلاب.

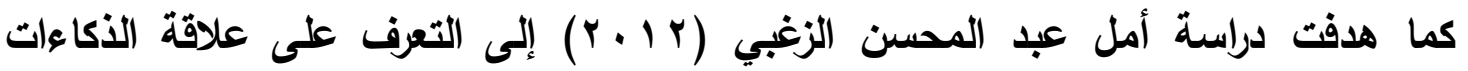

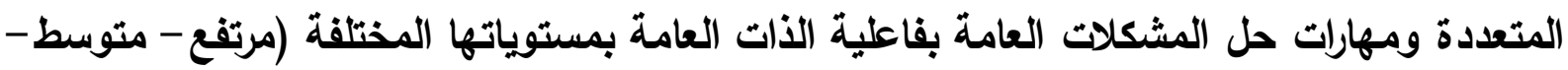

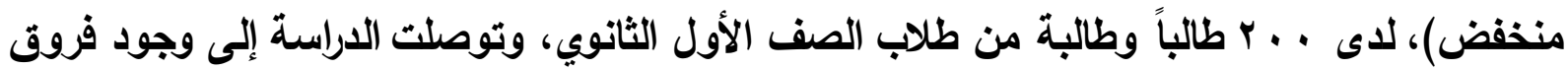

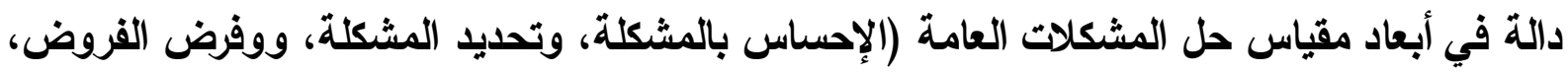
والتحقق من صحة الفروض) بين متوسطات درجات الطلاب ذوي مستويات فاعلية الأات العامة (مرتفع - متوسط - منخفض) لصالح الطلاب ذوي فاعلية الذات المرتفعة.

\section{( ) وجهة الضبط Locus of Control}

في خمسينيات القرن العشرين؛ إقترح روتر Rotter ( 19 ه 1 ) مفهوم وجهة الضبط، أي مركز الضبط في التعزيز المطلوب للسلوك، وقد يكون التحكم داخلياً وفيه ينسب الفرد نتائج أفعاله إلى نفسهاه، أو يكون خارجياً وفيه يعزو الفرد نتائج أفعاله إلى عوامل خارجية دون مسئوليته الثخصية .(Karbalaei, Abdollahi, Abu-Talib, Yaacob \& Ismail, 2013)

وتتعدد المصطلحات المستخدمة في البحوث واللاراسات التي تعبر عن مفهوم وجهة الضبط Locus of Control

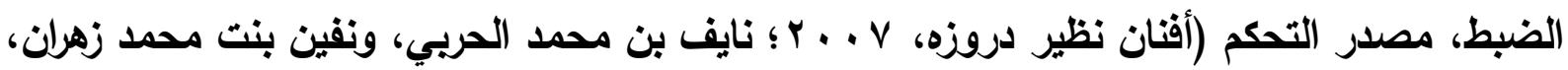

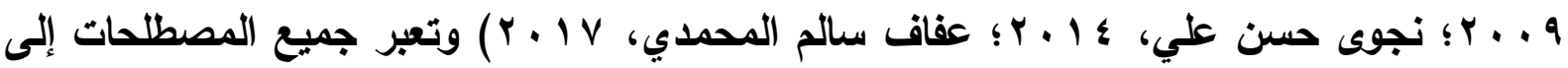


الوجهة التي يعتقد الفرد أنها المسئولة والمتحكمة في سلوكياته، ونتائج الأحداث والمواقق، ومصدر

ويختلط لاى البعض مفهوم "وجهة الضبط" الذي يعبر عن معثقدات الفرد وتوقعات عن العوامل

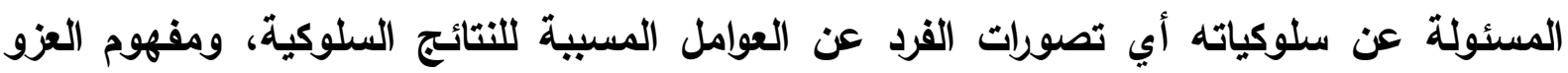

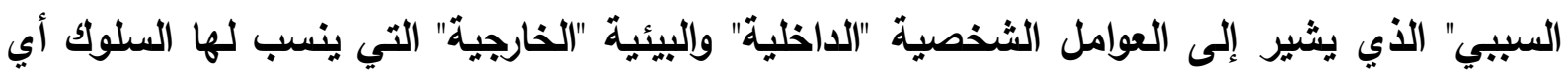
تفسر السلوك بعد حدوثئ.

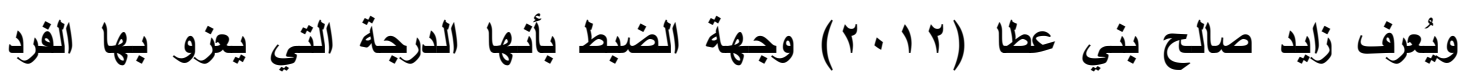
مسؤوليته عما يحدث له، مقابل أن ينسب نلك إلى قوى تقع خارج سيطرته، ويذلك يظهر نوعان من الضبط داخلي وخارجي.

Karbalaei, Abdollahi, ) ويشير كلاً من كاريالاي وعبد الله وأبو طالب وياسوب وإسماعيل (Abu-Talib, Yaacob \& Ismail, 2013 بإمكانهم السيطرة على شئون حياتهم، وينسبون نجاحهم أو فشلهم في تحقيق أهداف لمسئوليتهم

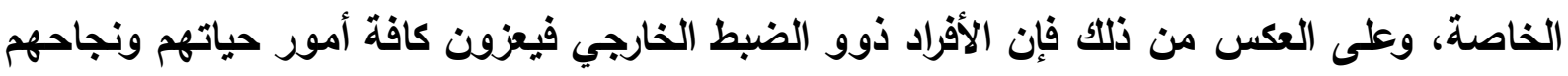

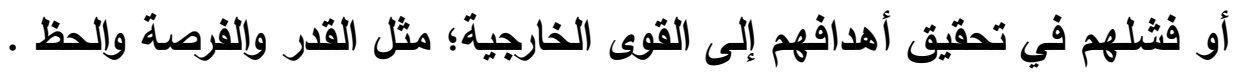

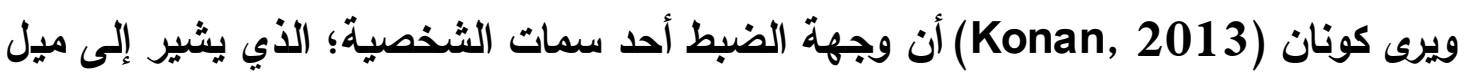

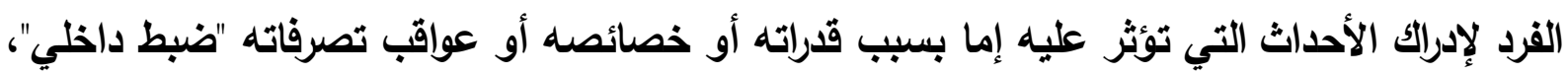
أو بسبب الصدفة والمصير والقوى الخارجة عن سيطرته "ضبط خارجي".

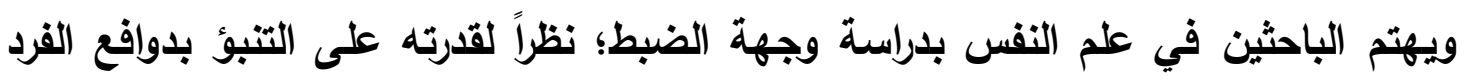

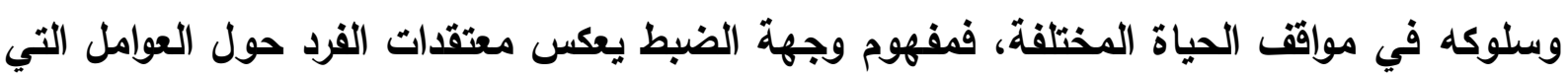

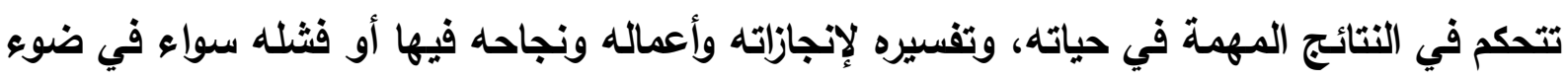
قراته أو للظروف الخارجية.

وإنبثق هذا المفهوم في منتصف ستينيات القرن الماضي إستناداً على نظرية التعلم الإجتماعي

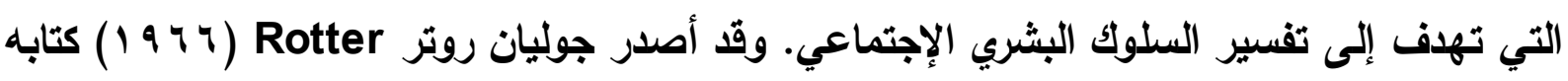

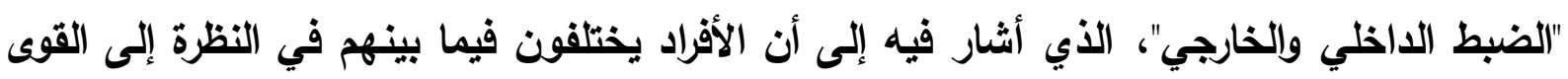

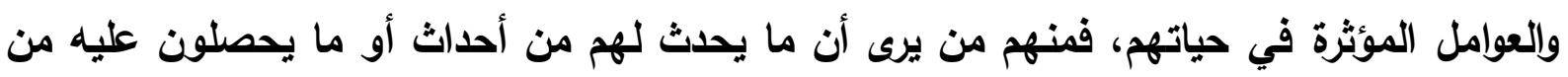

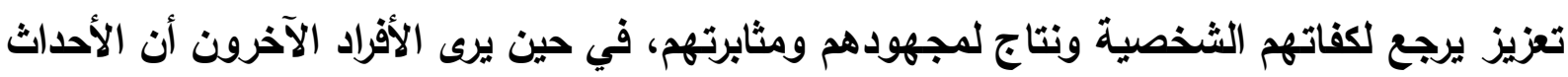

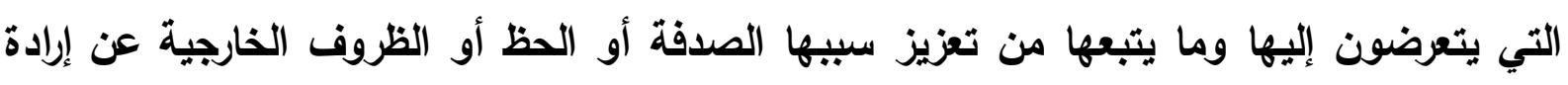

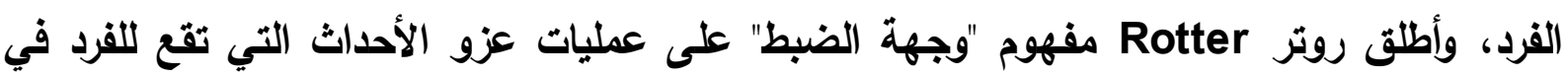

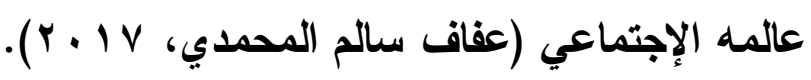


ويصنف الأفراد تبعاً لإدراكهم لمراكز الضبط في حياتهم إلى نوعين أساسبين؛ هما: ا - ذو الضبط الداخلي Internal Control: ويعتقد ذلك الفرد أنه المسئول عن ما يحدث لله من نتائج وأحداث أو ما يقوم به من سلوك، ويفسر الأحداث التي تحدث له بأسباب راجعة إلى عوامل

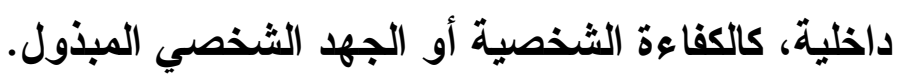
ץ - ذو الضبط الخارجي External Control: الذي يعتقد أن ما يحدث له من نتائج إيجابية أو سلبية، وما يقوم به من سلوك يعزو إلى عوامل خارجية تسيطر عليه مثل الحظ أو الصدفة أو

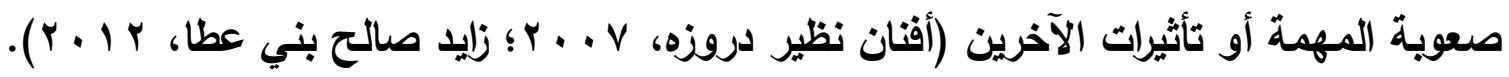
ويتصف الأفراد ذوو وجهة الضبط الداخلي بالقدرة على التحكم والسيطرة على سلوكياتهم وإتخاذ قراراتهم بقتاعة تامة، متحملين كافة النتائج المترتبة عليها، وأنهم أكثر فاعلية في معالجة المعلومات، وأكثر قدرة على حل المشكلات (نايف بن محمد الحربي، ونفين بنت محمد زهران، 9 . . ب). بينما يتصف ذوو وجهة الضبط الخارجي بميلهم لتنفيذ كافة الأمور الواجبة عليهم والمطلوية منهم، وإذا فشلوا ألقوا باللوم على الأخرين، ويتصفون أيضاً بالعفوية أو الجدية أو الإلتزام، وضعف الدافعية

$$
\text { (نجوى حسن علي، ع ا م.r). }
$$

وفيما يتعلق بالدراسات التي أجريت على طلاب الجامعة واللدراسات العليا لتحري وجهة الضبط

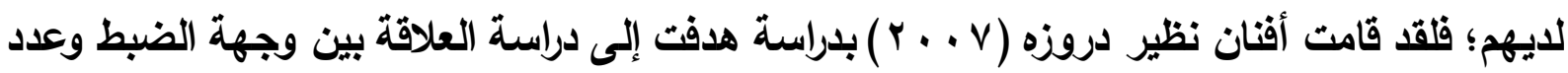
من المتغيرات (الجنس، والحالة الإجتماعية، والوضع المهني، ونوع المهنة، ورضاهم عنها، وعدد سنوات الخبرة، والجوائز التي حصلوا عليها، ورضاهم عن برنامج الماجستير، ورضاهم عن عملهم، وعن الحياة بشكل عام) لاى طلاب الدراسات العليا بكلية التربية في جامعة النجاح الوطنية بقلسطين. وأثارت النتائج إلى ميل الطلاب إلى الإنضبط الااخلي أكثر منه للإنضبط الخارجي، وعدم وجود فروق دالة في وجهة الضبط بين الطلاب الذكور والإناث، كما لا توجد فروق دالة بين الطلاب في وجهة الضبط بإختلاف تخصصهم، ولكن هناك فروق دالة بين الطلاب في وجهة الضبط وفقاً لوضع العمل؛ فالطلاب الذين يعملون يميلون لتبني وجهة الضبط الاخلي. كما هدفت دراسة إبتسام هادي العفاري (1 1 ( ب) إلى معرفة العلاقة بين وجهة الضبط والعوامل الخمس الكبرى في الشخصية لاى \& \& \& طالبة بجامعة أم القرى بمكة المكرمة، وأشارت نتائجها إلى

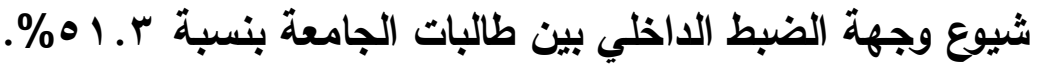
في حين أن دراسة عايش موسى غرايبة، وابراهيم عبد الله الزريقات (0 ا • r) التي سعت إلى معرفة نسبة طلاب الجامعة الذين يعزون نجاحهم أو إخفاقهم إلى عوامل خارجية أو عوامل داخلية،

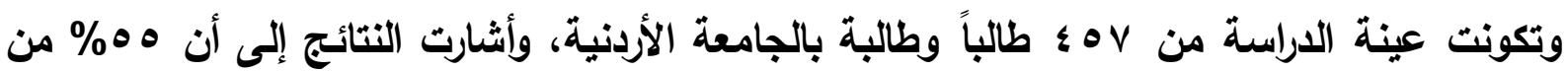


طلاب الجامعة يعزون نجاحهم أو فشلهم إلى عوامل خارجية، ولم تظهر النتائج أثر لمتغير الجنس ونوع الكلية في وجهة الضبط .

وأجريت العديد من الدراسات لتحديد العلاقة بين القدرة على حل المشكلات أو مهاراتها، ووجهة الضبط لاى الطلاب، من طلاب المدارس الإبتدائية إلى طلاب الدراسات العليا في مختلف الأعمار

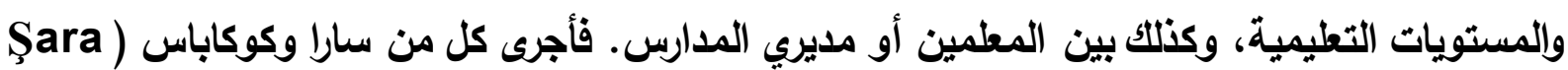
\& Kocabas, 2012

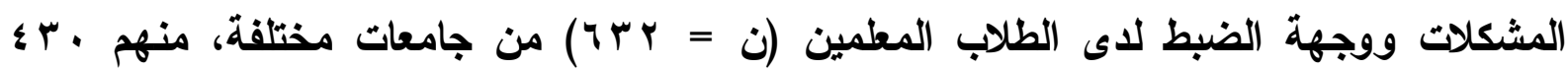

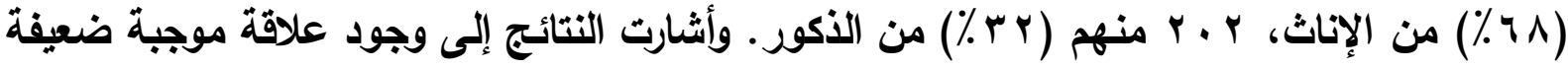
المستوى دالة إحصائياً بين وجهة الضبط الداخلي ومهارات حل المشكلات، وأمكن التتبؤ بوجهة الضبط من مهارات حل المشكلات. بينما هدفت دراسة كونان (Konan, 2013 (إلى تحديد العلاقة بين قدرة مديري المدارس على حل المشكلات ووجهة الضبط ، وتألفت عينة الدراسة من V9 مدير مدرسة ثانوية في المنطقة الوسطى من محافظة باتمان بتركيا. وأوضحت النتائج وجود علاقة منخفضة موجبة دالة بين درجات مديري المدارس الثانوية على مقياس وجهة الضبط وإستبيان حل المشكلات. Feldman, ) وتعددت الدراسات التي ربطت بين وجهة الضبط وفاعلية الأات، فإختبرت دراستة (Saletsky, Sullivan \& Theiss, 1983 والإستجابة للتوقعات الخاصة بفاعليتهن الذاتية وكفاءة المعمين، لاى عينة مكونة من هـ طالبة جامعية. وأكدات النتائج على وجود علاقة إيجابية بين الضبط الداخلي والفاعلية الذاتية، حيث أن الطالبات ذات المستوى العالي من فاعلية الذات لايهن القدرة على ضبط سلوكهن أثناء ممارسة الأنشطة التعليمية، كما أوضحت النتائج إلى أن الطالبات ذوات الضبط الداخلي أكثر توقعاً لأدائهن وفاعلية الأات لايهن من الطالبة ذوات الضبط الخارجي. وفي دراسة كاريفيو وروديس (Carifio \& Rhodes, 2002) لتقصي العلاقة بين التفاؤل والتأمل وفاعلية الذات ووجهة الضبط لاى ع ؛ طالباً وطالبة بالجامعة، منهم r r طالباً على قدر مناسب من السواء التفسي، و Y Y آخرون لايهم إستعداد للتأثر بالمشكلات التفسية. وأظهرت النتائج أن الأفراد ذوي فاعلية الأات العالية والذين على قدر مناسب من السواء النفسي يتبنون وجهة ضبط داخلية، بينما إرتبطت وجهة الضبط الخارجية سلبياً بالإعتقاد بفاعلية الذات العالية. وفحصت دراسة نايف بن محمد الحربي، ونفين بنت محمد زهران (9 ، . r ) العلاقة بين فاعلية الذات ووجهة الضبط في ضوء المرحلة الاراسية والمستوى الإجتماعي والإقتصادي لاى ، ^ ط طالبة من طالبات الفرقتين الأولى والرابعة بكلية التربية للبنات بالمدينة المنورة، وأشارت النتائج إلى إرتباط 
إعتقاد الأفراد بفاعلية الذات سلبياً بوجهة الضبط الخارجية. كما أظهرت النتائج وجود فروق دالة بين متوسطات درجات طالبات الفرقة الأولى والرابعة في كل من درجة الإعتقاد في فاعلية الذات وفي تبني وجهة الضبط الداخلية.

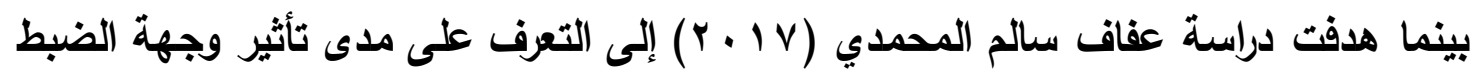
(الداخلي، والذارجي) وفعالية الذات على التحصيل الدراسي لطالبات المرحلة الثانوية، ويلفت عينة الدراسة ؟ ك طالبة من طالبات المرحلة الثانوية من ست مدارس حكومية بمدينة الرياض، وأوضحت

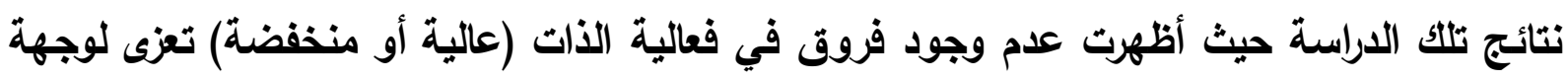
الضبط (داخلي، وخارجي).

\section{التعليق على الإطار النظري، واللدراسيات السابقة:}

1 - تنوعت الأدوات المستخدمة في الدراسات السابقة لقياس القدرة على حل المشكلات الإحصائية

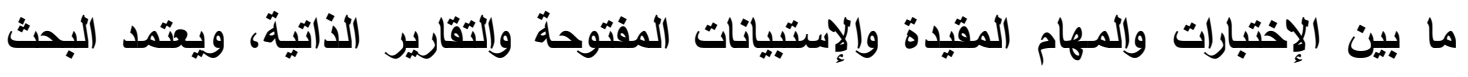

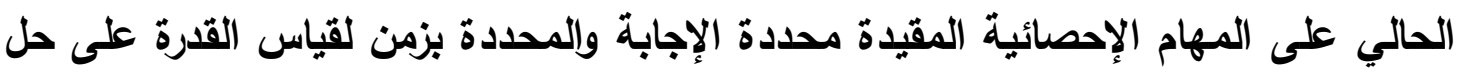
المشكلات.

r - تنوعت المراحل العمرية لعينات الدراسات السابقة لتشمل جميع المراحل التعليمية، ولكن تتدر

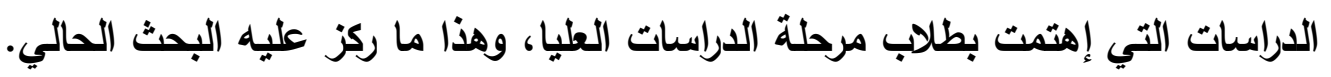

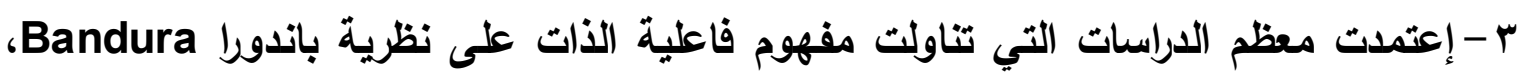

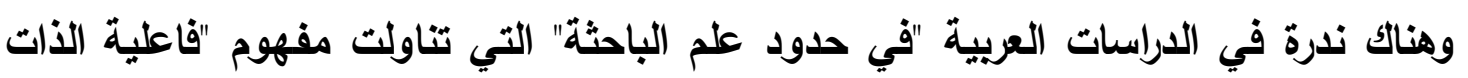
البحثية".

؛ - وجدت أغلب الدراسات السابقة علاقات إرتباطية بين متغيرات البحث (القدرة على حل المشكلات، التتافر المعرفي، فاعلية الذات، وجهة الضبط)، ودراسة الفروق في تلك المتغيرات وفقاً لبعض المتغيرات مثل النوع والتخصص. ولكن لم توجد دراسة تناولت العلاقات السبية والتبادلية بين تلك المتغيرات.

فروض البيجة

صنفت متغيرات البحث إلى نوعين؛ متغيرات مستقلة وتتمثل في التنافر المعرفي، ووجهة

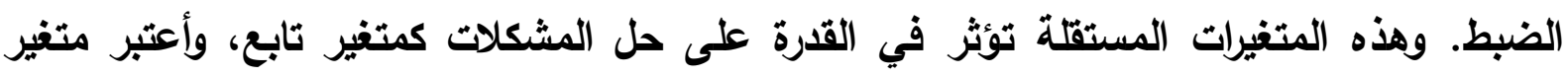
فاعلية الذات البحثية متغيراً وسيطاً يؤثر في القدرة على حل المشكلات الإحصائية ويتأثر بالتنافر المعرفي ووجهة الضبط. وسعى البحث إلى إختبار الفروض التالية: ا. مستوى التنافر المعرفي لدى طلاب الدراسات العليا بكلية التربية جامعة قناة السويس الفيلة متوسطاً. 
r. مستوى فاعلية الأت البحثية لاى طلاب الاراسات العليا بكلية التربية جامعة قناة السويس

\section{منخفضاً.}

r. يتبنى طلاب الدراسات العليا بكلية التربية جامعة قناة السويس وجهة ضبط خارجي. ع. توجد فروق دالة في القدرة على حل المشكلات الإحصائية لدى طلاب الدراسات العليا بكلية التربية جامعة قناة السويس تعزى لإختلاف كل من المستوى الدراسي (د.خاص، وماجستير، ودكتوراه) والتخصص (علم نفس، وتربية خاصة، وصحة نفسية) والتفاعل بينهما. هـ توجد تأثيرات سببية بين القدرة على حل المشكلات الإحصائية كمتغير تابع، ووجهة الضبط، وأبعاد التتافر المعرفي (البعد الشخصي، والبعد الإجتماعي) كمتغيرات مستقلة، من خلال أبعاد فاعلية الذات البحثية (المبادأة والمثابرة، وتحمل المسئولية البحثية، والثقة بالنفس) كمتغير

\section{وسيط.}

وقد اقترحت الباحثة نموذجاً سببياً للتحقق من هذا الفرض، يفسر العلاقات الإرتباطية بين المتغيرات موضع البحث على النحو الموضح بالشكل التالي:

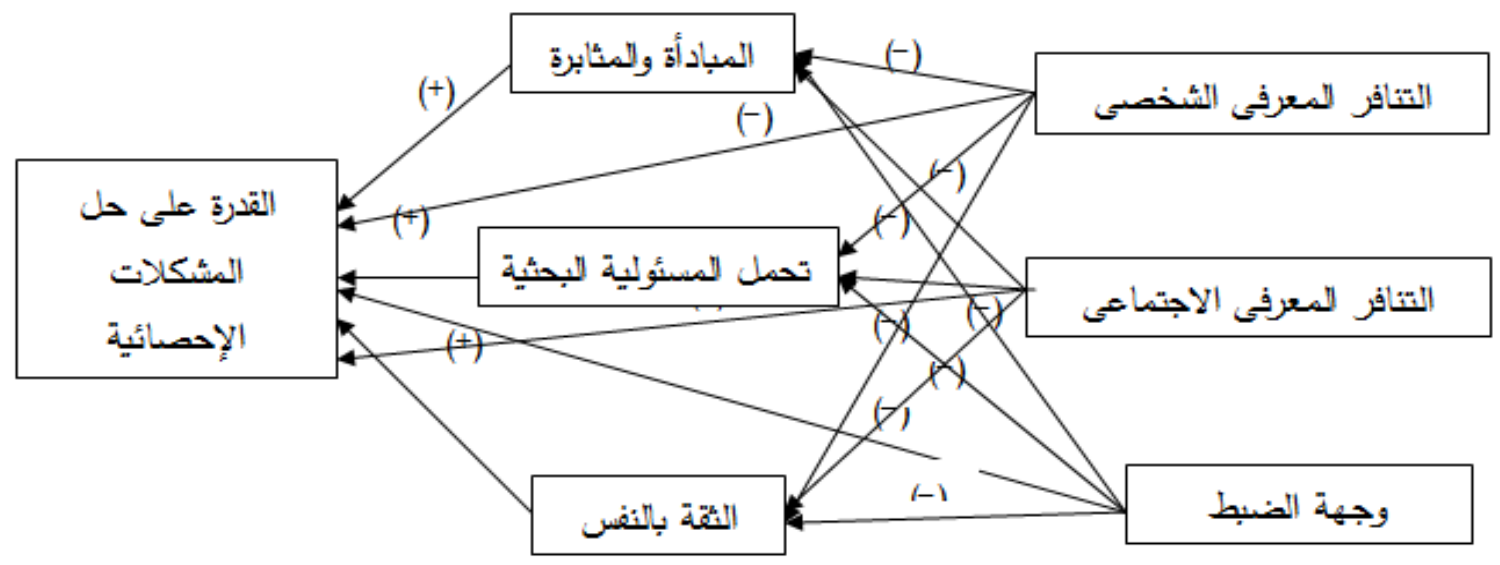

شكل (1) النموذج السببي المقترح للفرض الخامس

المطريقة والإجراعاتٌ

(أ) منهج البحث: إعتمد البحث الحالي على المنهج الوصفي للإجابة على أسئلة البحث والتحقى من

(ب) مجتمع البحث وعينته: يتمثل مجتمع البحث الحالي في طلاب الدراسات العليا بكلية التربية جامعة

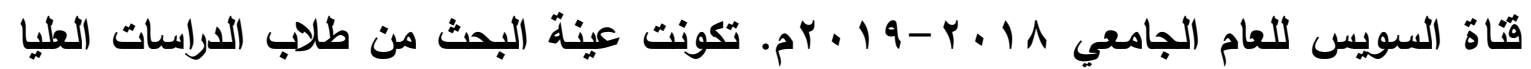
(بالابلوم خاص، والماجستير، والدكتوراه) في التخصصات المختلفة (علم نفس، تربية خاصة، الصحة النفسية)، وإقتصر البحث على هذه التخصصات نظراً لتقارب مجالات البحث فيهم مما يفيد في تفهم الطلاب للمشكلات البحثية المكونة لمقياس القدرة على حل المشكلات الإحصائية. ويلغ عدد أفراد العينة ( • 1 1) طالباً وطالبة. وصنفت العينة إلى نوعين: 
1 - عينة التحقق من الخصائص السيكومترية: واشتقت بطريقة عشوائية، ويلغ عددها ( • •) طالباً وطالبة، وطبقت عليها جميع أدوات البحث للتحقق من مؤشرات الصدق والثبات لكل منها. ويلغ

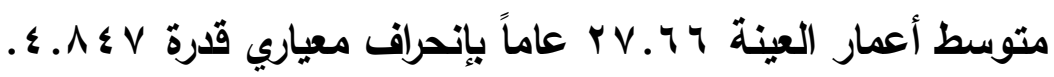

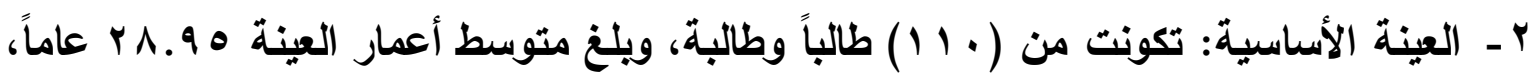
والإنحراف المعياري هـ هـ ـ ـ والجدول التالي يوضتح توزيع أفراد العينة الأساسبة: جدول (1) توزيع أفراد العينة الأساسية

\begin{tabular}{|c|c|c|c|c|c|c|}
\hline \multirow{2}{*}{ الإنحراف المعياري } & \multirow{2}{*}{ متوسط العمر } & \multicolumn{3}{|r|}{ التخصص } & & \multirow{2}{*}{ المتغير } \\
\hline & & الصحة النفسية & علم نفس & تربية خاصة & & \\
\hline r.АTV & r9.7V & 7 & $r$ & 7 & ذكر & \multirow{2}{*}{ النوع } \\
\hline$\varepsilon .701$ & rA.Ar & rq & $r \leq$ & $\leqslant 0$ & انثى & \\
\hline$\varepsilon .990$ & PV.97 & 1. & 1. & ro & دبلوم خاص & \multirow{4}{*}{ المستوى } \\
\hline$\varepsilon .19 \varepsilon$ & Yq.Y. & 18 & ir & $r \cdot$ & ماجستير & \\
\hline$r .000$ & $r 1 . . v$ & 0 & $\varepsilon$ & 7 & دكتوراه & \\
\hline$\varepsilon .0 \leq 0$ & r^.90 & & & 11. & المجموع & \\
\hline
\end{tabular}

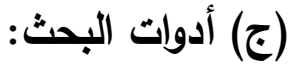
ا ـ مقياس القدرة على حل المشكلات الإحصائية (إعداد الباحثة): هدف المقياس تحديد القدرة على حل المشكلات الإحصائية لاى طلاب الدراسات العليا، وقامت الباحثة بمسح للاراسات والبحوث السابقة (في حدود المتاح) التي تناولت القدرة على حل المشكلات، والإطلاع على المقاييس المتضمنة في الاراسات السابقة، ومنها:

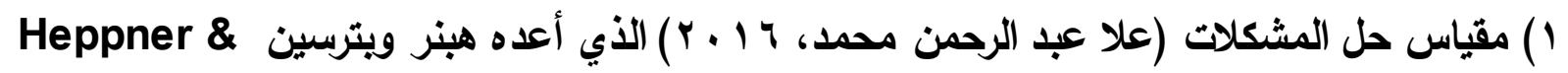
عام r Petersen الشخصية في واقع الحياة. ويتكون من · ع فقرة تصف الطريقة التي يستخدمها الناس عادةً في التعامل مع المشكلات الحياة اليومية، وتوزع الققرات على خمس أبعاد لمهارات حل المشكلة (هى هـ التوجه العام، وتعريف المشكلة، وتوليد البدائل، وإتخاذ القرار، والتقييم) بواقع ثماني فقرات لكل بعد، ويستجيب الفرد على مقياس متدرج رياعي بإختيار أحد البدائل (تنطبق بلرجة كبيرة، تتطبق بلرجة

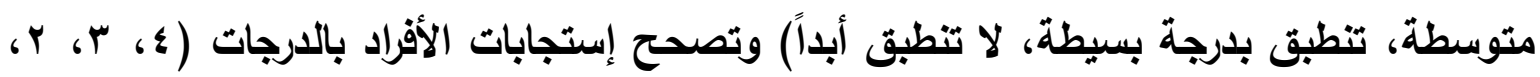

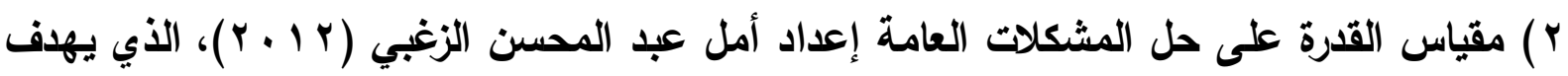
إلى قياس مهارات حل المشكلات العامة لاى عينة من طلاب المرحلة الثانوية، وتكون المقياس من rr مفردة تعبر كل منها عن موقفاً لحل المشكلات، وتتوزع تلك المفردات بالتساوي على أربعة 
أبعاد فرعية تمثل مهارات لحل المشكلات هى الإحساس بالمشكلة، وتحديدها، وفرض الفروض، والتحقق من صحة الفروض.

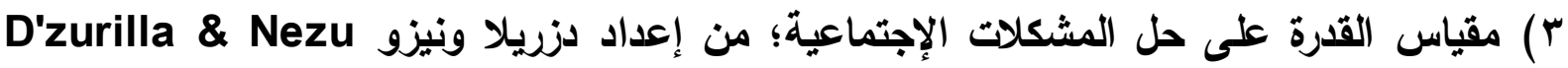

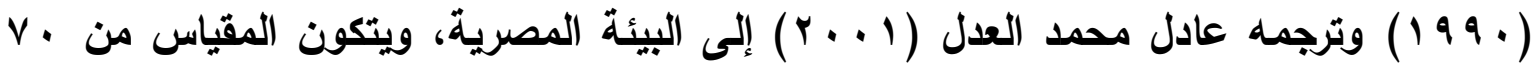
مفردة تمثل تقريراً ذاتياً للقدرة على حل المشكلات الإجتماعية، موزعة على مقياسين رئيسيين

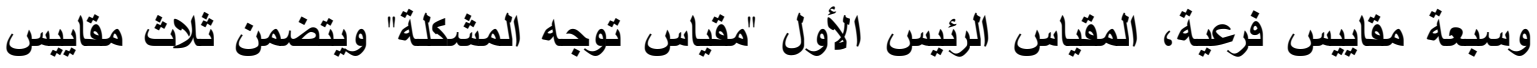

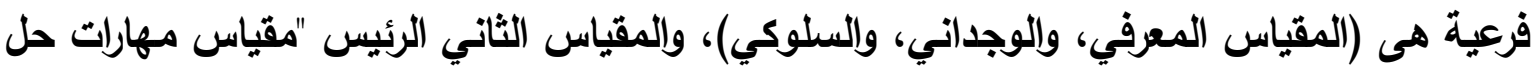
المشكلة" الأي يتضمن أريعة مقاييس فرعية (مقياس صياغة المشكة وتحديدها، ومقياس إنتاج الحلول البديلة، مقياس صنع القرار، مقياس وسيلة الحل والتحقق). ولكل مفردة خمس إستجابات

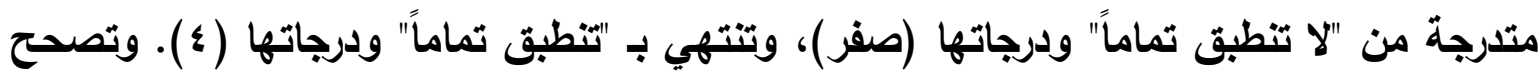
المفردات السلبية بطريقة عكسية، وتعبر الدرجة المرتفعة عن قدرة عالية على حل المشكلات.

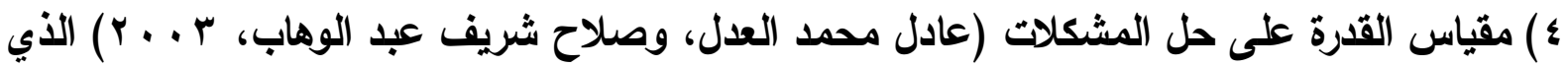
يهدف إلى قياس قدرة الفرد على إستخدام الرموز للوصول إلى تحقيق هدف معين يصع تحقيقه بأساليب السلوك المعتادة، وتكون من ثلاثة مجموعات من المهام الإختبارية، تحتوى كل مجموعة على عدد من المهام والتعليمات الخاصة بها، ومثالاً على كل مهمة لتوضيح المطلوب. وفي

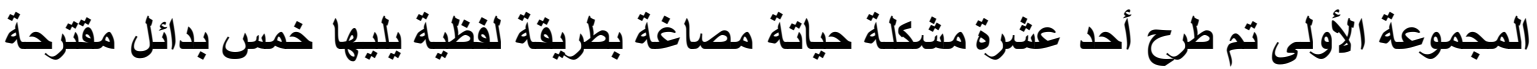
للحلول (ومن أمثلة المشكلات التي تدور حولها تلك المهام مشكلة التصحر وتلوث البيئة وإتفاع

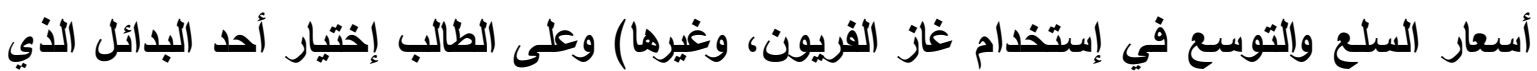
يعد حلاً مناسباً للمشكلة المطروحة في زمن قدره ـ وفي المجموعة الثانية تم طرح عشر مشكلات رياضية مصاغة بإستخدام الرموز والحروف الأبجدية تدور حول بعض المفاهيم الرياضية مثل فئل

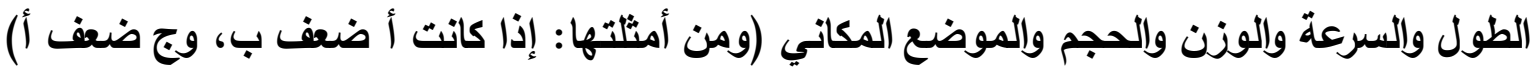
ويليها عدد من الافتراضات تصف العلاقات بين الرموز المستخدمة وعلى الطالب إختيار البديل الذي واني

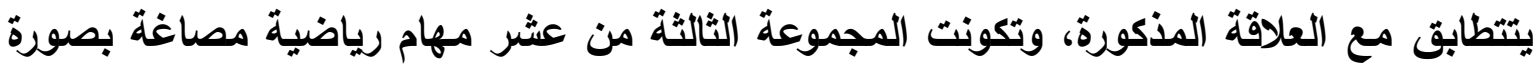

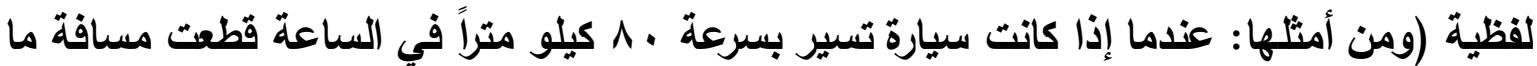

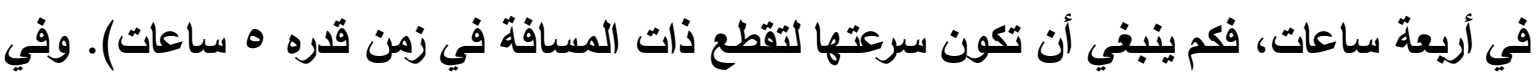

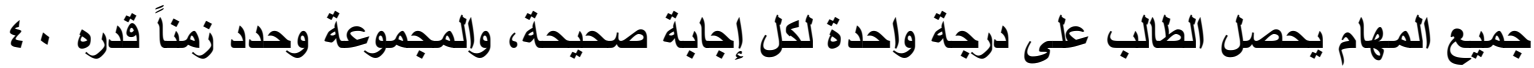
دقيقة للإجابة على الثلاثة مجموعات من المهام. 


\section{وصف مقياس القدرة على حل المشكلات الإحصائية ؛}

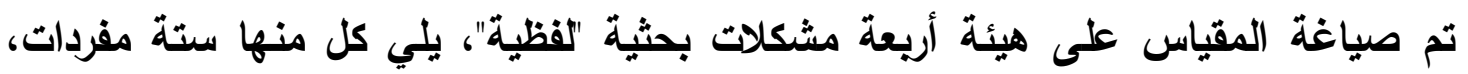

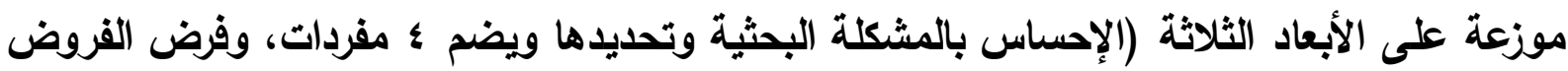

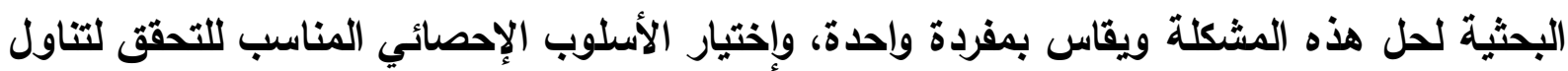

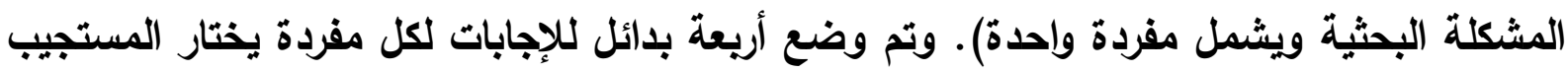

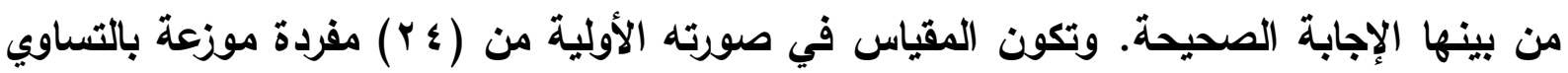
على الأربعة مشكلات.

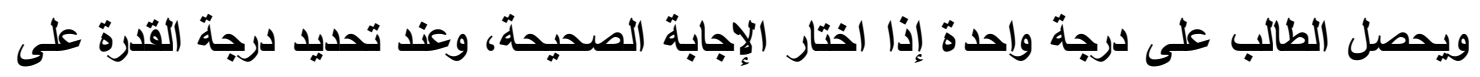

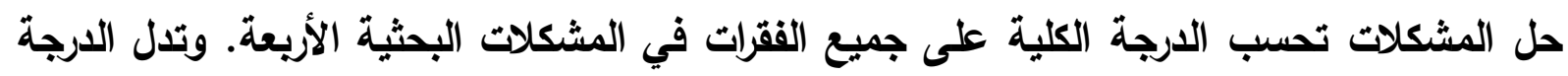

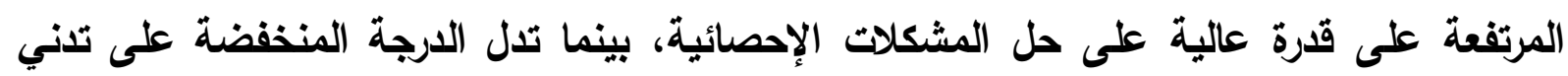
مستوى القدرة على حل المشكلات الإحصائية. التحقق من الخصائص السيكومترية للمقياس: أولاً: صدق المحتوى للمقياس: تم عرض المقياس في صورته الأولية على عدد من المحكمين من

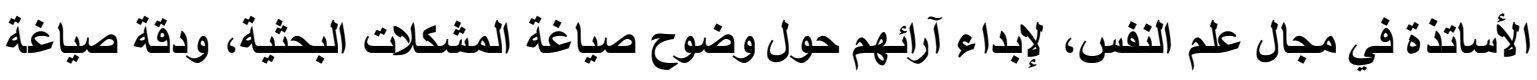

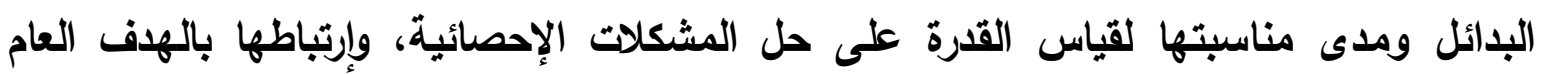
للبحث.

وقد إقترح المحكمن أن تعاد صياغة السؤال الخامس على كل مشكلة والمتعلق بتحديد

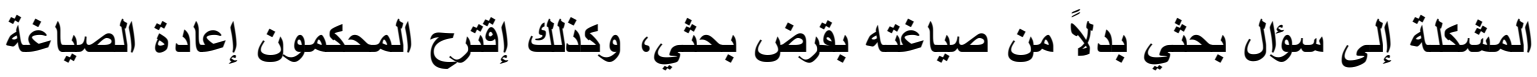

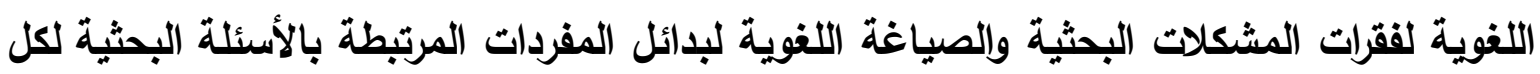
مشكلة، وقد تم مراعاة ذلك في الصورة النهائية.

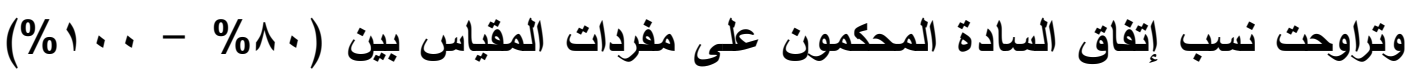

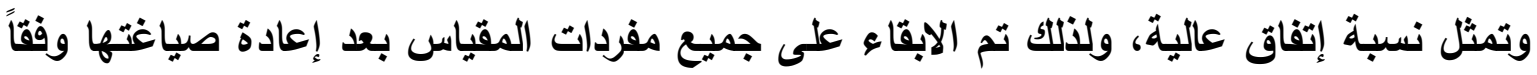
لآراء السادة المحكمين. ثانياً: الإتساق الإخلي للمقياس: تم حساب معارمل الإرتباط بين درجات الطلاب على كل مفردة

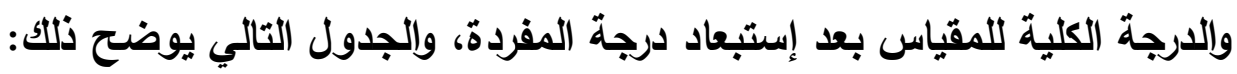


جدول (Y) معاملات الإرتباط بين درجة كل مفردة بالدرجة الكلية لمقياس القدرة على حل المشكلات بعد إستبعاد درجة المفردة

\begin{tabular}{|c|c|c|c|c|c|c|c|}
\hline (১) & رقم المفردة & $(\jmath)$ & رقم المفردة & $(\jmath)$ & رقم المفردة & (১) & رقم المفردة \\
\hline "**".r40 & 19 & $=" . r . q$ & ir & "*** . . & v & "*** $\ldots$. r & 1 \\
\hline .rYI & $r$. & "** . & $1 \leq$ & "*** . . & $\wedge$ & $* * \ldots$ * .80 & $r$ \\
\hline. .404 & r & ${ }^{* *}, \ldots 17$ & 10 & ${ }^{* * *}, 0 \leq r$ & 9 & *** .04 & $r$ \\
\hline ** . rVY & rr & 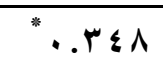 & 17 & *** . . & 1. & *** . . & $\varepsilon$ \\
\hline$" . r \leq 0$ & rr & $* * \ldots 01$ & IV & ***.$r V q$ & 11 & $" . r \Delta \Lambda$ & 0 \\
\hline q " & $r \leqslant$ & .874 & 11 &.$r V$. & Ir & ***.rq9 & 9 \\
\hline
\end{tabular}

ويتضح من الجدول السابق أن أغلب معاملاث الإرتباط للمفردات بالدرجة الكلية للمقياس

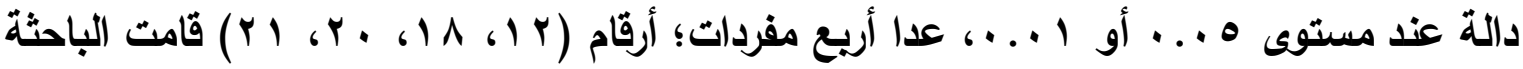
بحذفها. وتشير النتائج إلى تمتع المقياس بالإتساق الداخلي في قياس القدرة على حل المشكلات الإحصائية.

ثالثاً: ثبات المقياس: تم التحقق من ثبات مقياس القدرة على حل المشكلات كما يلي: ا.بطريقة التجزئة النصفية: ويلغت قيمة معامل الثبات قبل التصحيح م 01 ه. ، وجاعت قيمة معامل

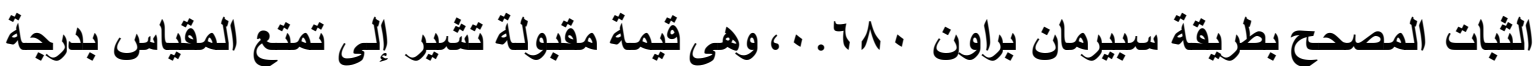
ثبات مرتفعة ويؤكد صلاحية إستخدام هذا المقياس. r.بطريقة ألفا كرونباخ: تم حساب معامل الثبات للمقياس ككل، وكاتت قيمته معامل ثبات ألفا 9 9 . . . ، كما تم حساب معامل ثبات ألفا بعد إستبعاد درجة كل مفردة من الدرجة الكلية للمقياس،

$$
\text { كما بالجدول التالي: }
$$

جدول (ب) قيمة ألفا لمقياس القدرة على حل المشكلات "بعد إستبعاد" درجة كل مفردة (ن = • •)

\begin{tabular}{|c|c|c|c|c|c|c|c|}
\hline قيمة ألفا & رقم المفردة & قيمة ألفا & رقم المفردة & قيمة ألفا & رقم المفردة & قيمة ألفا & رقم المفردة \\
\hline זדV.. & $r \mu$ & $\because v \otimes v$ & $1 \leqslant$ & $\therefore V \otimes V$ & V & .V71 & 1 \\
\hline & $Y \varepsilon$ & .V7 & 10 & $\therefore V 0 \leqslant$ & $\wedge$ & .VOr & $r$ \\
\hline \multirow{4}{*}{\multicolumn{2}{|c|}{ 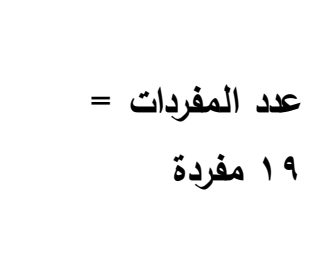 }} & rVTV & 17 & $\Rightarrow v \leqslant q$ & 9 & $\because V \leqslant V$ & $r$ \\
\hline & & .vor & iv & $\cdots \vee 04$ & 1. & $\because \vee 01$ & $\varepsilon$ \\
\hline & & A & 19 & .VTr & 11 & .874 & 0 \\
\hline & & . & rr & $\ldots \vee \vee 1$ & ir & זדV.. & 7 \\
\hline
\end{tabular}


ويمقارنة قيمة ثبات ألفا للمقياس ككل (9 9 و . · ) بقيمة ثبات ألفا بعد حنف المفردة من الارجة

$$
\text { الكلية للمقياس؛ تم حذف المفردة رقم ( ( ) . }
$$

وفي الصورة النهائية للمقياس بلغ عدد المفردات 9 المفردة. وتتراوح درجات الطلاب عليه بين "صفر" و" 9 ا"، ولتحديد مستوى القدرة على حل المشكلات الإحصائية تم تقسيم مدى الدرجات لثلاث

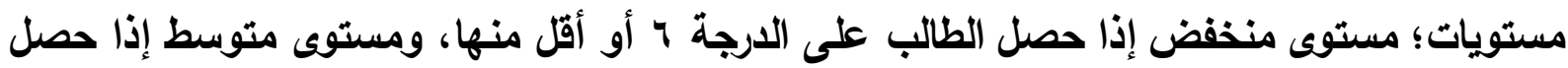

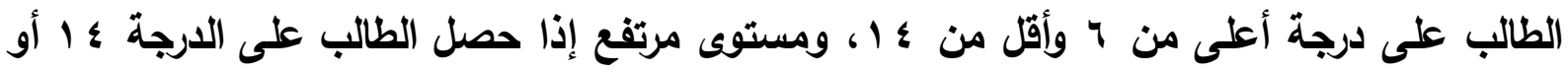

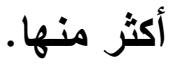

r ـ مقياس التنافر المعرفي (إعداد الباحثة): يهدف مقياس التنافر المعرفي إلى تحديد درجة تعارض النسق المعرفي لطالب الاراسات العليا

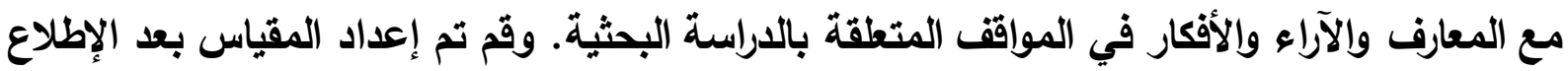
على عدد من المقاييس المتاحة، ومنها: Cassel, Chow, \& Reiger, ) مقياس التنافر المعرفي الذي أعده كل من كسل وشو ومئه

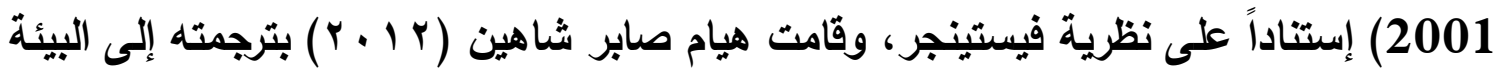

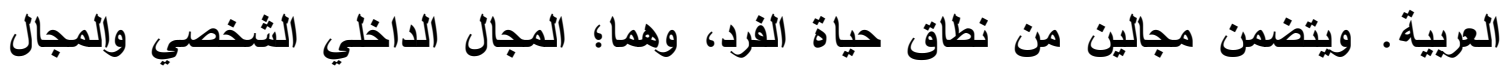

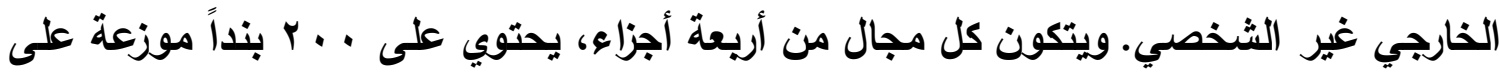

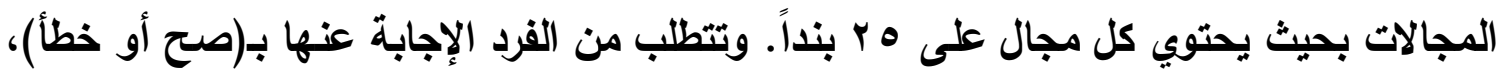

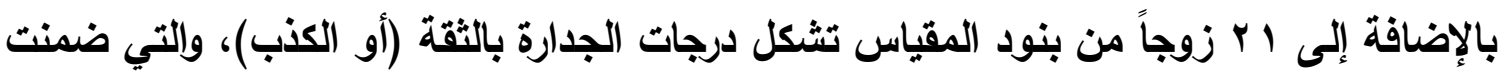
للتأكد من أن البنود تقرأ و/أو تفهم بطريقة صحيحة. والمجالات الهات (هي: المسكن والأسرة، والتحكم

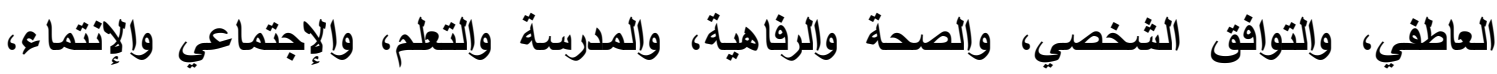

$$
\text { والهيمنة والقوة، والإستمرار والدايمومة). }
$$

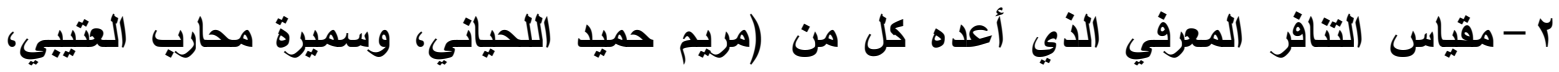

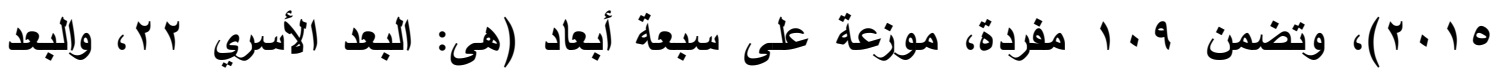

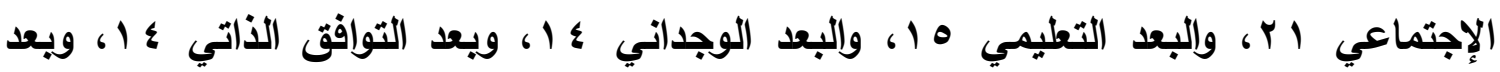

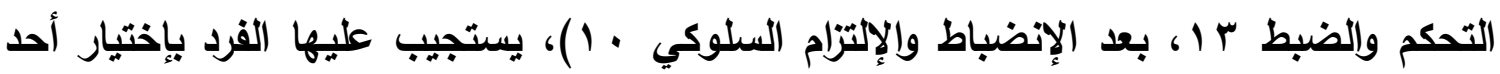

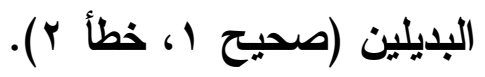

\section{وصف الصورة الأولية لمقياس التنافر المعرفي ؛}

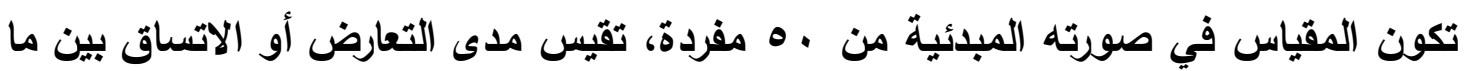

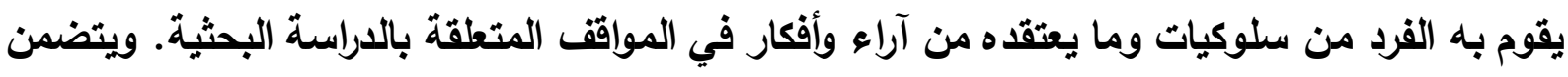

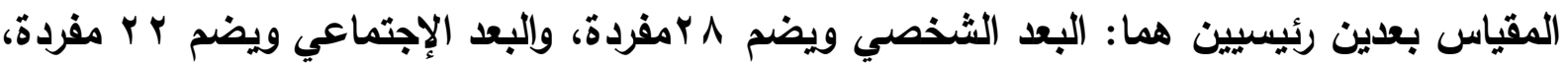


بحيث تغطي مفردات المقياس حالة التعارض المعرفي التي يمر بها طالب الدراسات العليا في مجال البحث العلمي.

ويستتجيب الطالب على كل فقرة بإختيار أحد البدائل على تدريج خماسي الاستجابات؛ بحيث

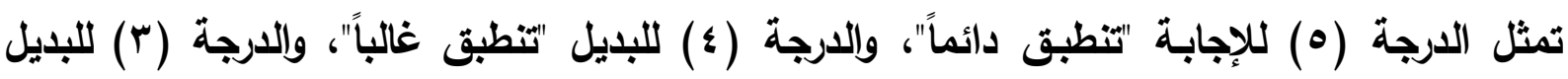

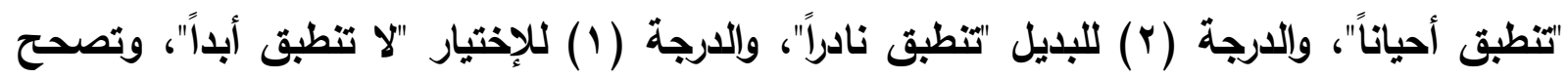

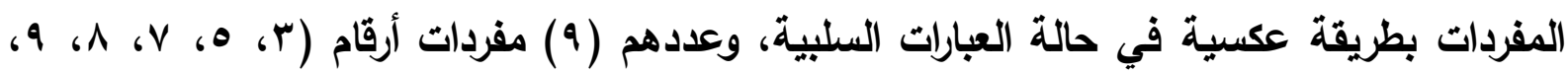

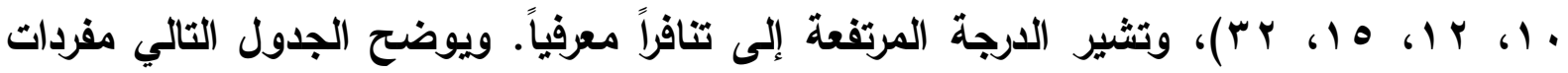
المقياس على البعدين في صورته الأولية.

جدول (؛ ) أبعاد مقياس التنافر المعرفي وأرقام المفردات المتضمنة في كل بعد في صورته الأولية

\begin{tabular}{|c|c|c|c|}
\hline مفردات كل بعد & أرقام المفردات في الصورة الأولية للمقياس & 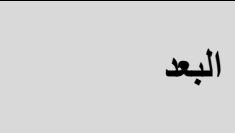 & b \\
\hline$r \wedge$ & 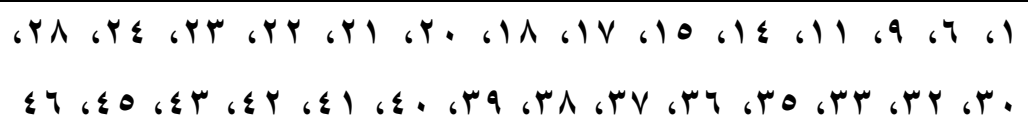 & البعد الشخصي & 1 \\
\hline rr & 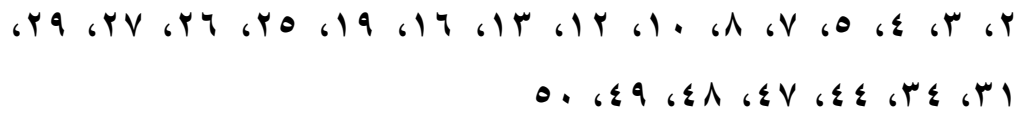 & البعد & r \\
\hline 0 . & & ي عدد المفردات & \\
\hline
\end{tabular}

التحقق من الخصائص السيكومترية للمقياس: أولاً: صدق المحتوى لمقياس التنافر المعرفي: تم عرض المقياس في صورته الأولية على مجموعة من المحكمين في مجال علم النفس؛

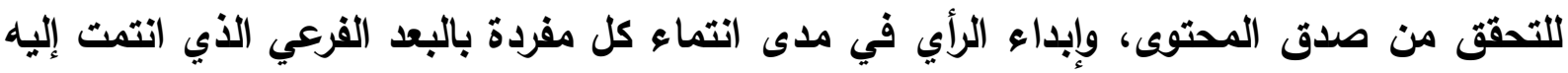
(الثخصي، والإجتماعي)، ومدى وضوح صياغة مفردات المقياس، ومدى مناسبة صياغة المفردات

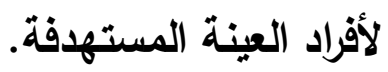

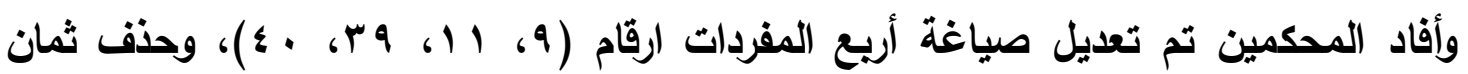

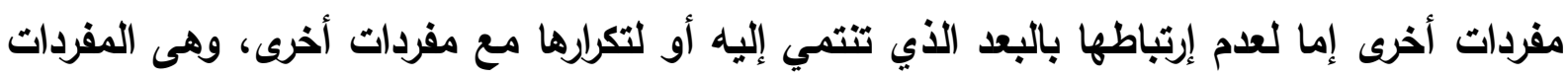

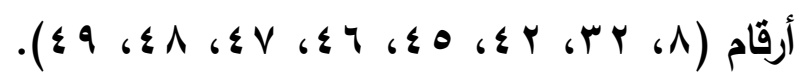

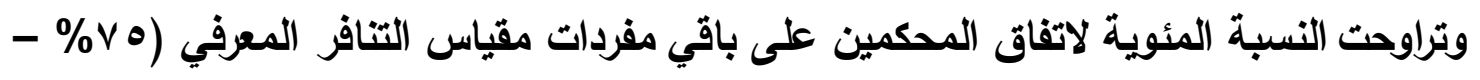

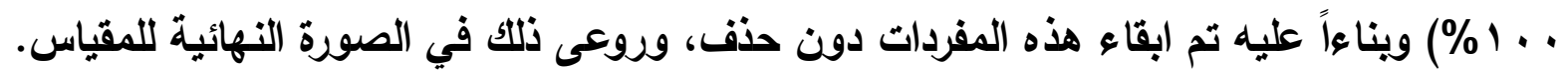
ثانياً: الإتساق الداخلي لمقياس التنافر المعرفي: قامت الباحثة بحساب معامل إرتباط بيرسون بين درجة كل مفردة والدرجة الكلية للبعد الذي الذي

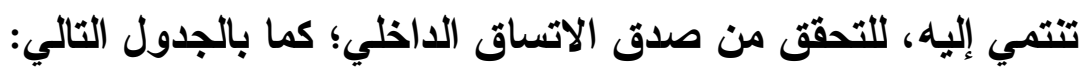


جدول (•) معاملات الإرتباط بين درجة كل مفردة بلرجة البعد التي تتنمي إليه في مقياس التنافر

\begin{tabular}{|c|c|c|c|c|c|c|c|}
\hline \multicolumn{4}{|c|}{ البعد الإجتماعي } & \multicolumn{4}{|c|}{ لبعد الشخصي } \\
\hline$(\jmath)$ & رقم المفردة & $(\jmath)$ & رقم المفردة & $(\jmath)$ & رقم المفردة & $(\jmath)$ & رقم المفردة \\
\hline " & 19 & **** & r &.$Y_{1}$ & $r \varepsilon$ & "*** & 1 \\
\hline *** . & ro & *** & $\boldsymbol{\mu}$ & *** . E YY & 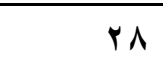 & $* * . \mu \vee \varepsilon$ & 7 \\
\hline$* * \ldots \wedge \mu$ & rq & $* * .0 p q$ & $\varepsilon$ & $. r \leqslant 7$ & $\mu$ &.$Y .0$ & 9 \\
\hline *... & YV & $* * . .7 \wedge \Lambda$ & 0 & *** . . & س & * . . & 11 \\
\hline$* * .01 Y$ & pq & *.. $\mathrm{kqV}$ & $V$ & $* * 0 . V$ & ه & $* * . . \varepsilon p q$ & $1 \varepsilon$ \\
\hline 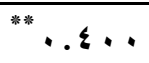 & r & $* * .0$. & 1 & $* * \ldots \& \Lambda$ & Y w &.$Y 0$. & 10 \\
\hline$* * .01 \varepsilon$ & $\mu \varepsilon$ &. .77 & Ir & $* * . \% q \Lambda$ & $\mu v$ & $* * .0 . \mu$ & 18 \\
\hline$* * .0 \vee 9$ & $\varepsilon \varepsilon$ & $* * . \leqslant \vee 1$ & 1 & $* . \mu \leq 1$ & $\mu \Lambda$ & $* * \ldots, \mu$ & 11 \\
\hline ט & - . & $\therefore \wedge \varepsilon$ & 17 &. $.1 \wedge \Lambda$ & rq & *.. & $r$. \\
\hline & $r \varepsilon=$ & بعد الشخص & عدد & $* * . . \varepsilon 9 \varepsilon$ & $\varepsilon$. & $* * 71 \%$ & Y \\
\hline & $1 \Lambda=$ & بعد الإجتم & عدد مفرداث &..$Y Y V$ & $\varepsilon 1$ &..$Y V Y$ & $r r$ \\
\hline & & مفرداث = & اجمالي عدد & $* .0 . Y$ & $\varepsilon$ & $* * .0 Y 1$ & rr \\
\hline
\end{tabular}

$\bullet \cdot=\dot{0}$

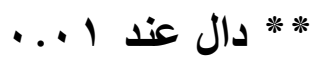

مال عند ...

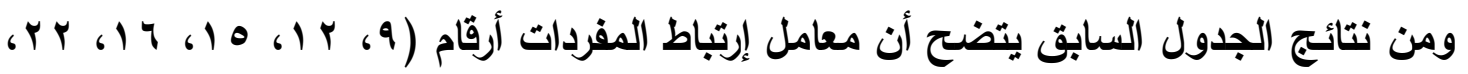

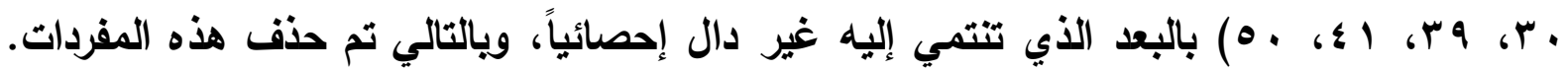
ويذلك أصبح عدد مفردات المقياس بr مفردة (1/ مفردة بالبعد الشخصي، وها مفردة بالبعد (الإجثماعي).

ثالثاً: ثبات مقياس التنافر المعرفي: قامت الباحثة بالتحقق من ثبات المقياس كما يلي: اـ الثبات بطريقة التجزئة النصفية: تم إستخدام طريقة التجزئة النصفية لحساب ثبات كل بعد على حده ويوضح الجدول رقم (7) قيمة معامل الثبات بطريقة التجزئة النصفية لأبعاد مقياس التنافر المعرفي، وقيمة معامل الثبات المصحح بطريقة سبيرمان براون. جدول ( ا ) قيمة معامل الثبات بطريقة التجزئة النصفية لأبعاد مقياس التنافر المعرفي (ن = •)

\begin{tabular}{|c|c|c|c|}
\hline كل بُعد مفردات & المصحة $\quad$ (سبيرمان سبراون) & قيمة قاتبات $\quad$ قامل & الأبعاد \\
\hline 11 & $\because V \cdot V$ & $.0 \leq 4$ & البعد الشخصي \\
\hline 10 & $\because V \otimes V$ & $\cdot .7 \cdot 1$ & البعد الإجتماعي \\
\hline
\end{tabular}


r. الثبات بطريقة ألفا كرونباخ: بحساب قيمة معامل الثبات بإستخدام طريقة ألفا كرونباخ لحساب الثبات لكل بُعد من أبعاد المقياس كلٍ على حده، ويوضح الجدول التالي قيمة معامل ثبات ألفا لكل ويعد، وقيمتها بعد استبعاد درجة كل مفردة من درجة البعد الذي تنتمي إليه: جدول (V) قيمة ألفا لمقياس فاعلية الذات البحثية "بعد استبعاد" درجة كل مفردة (ن = • •)

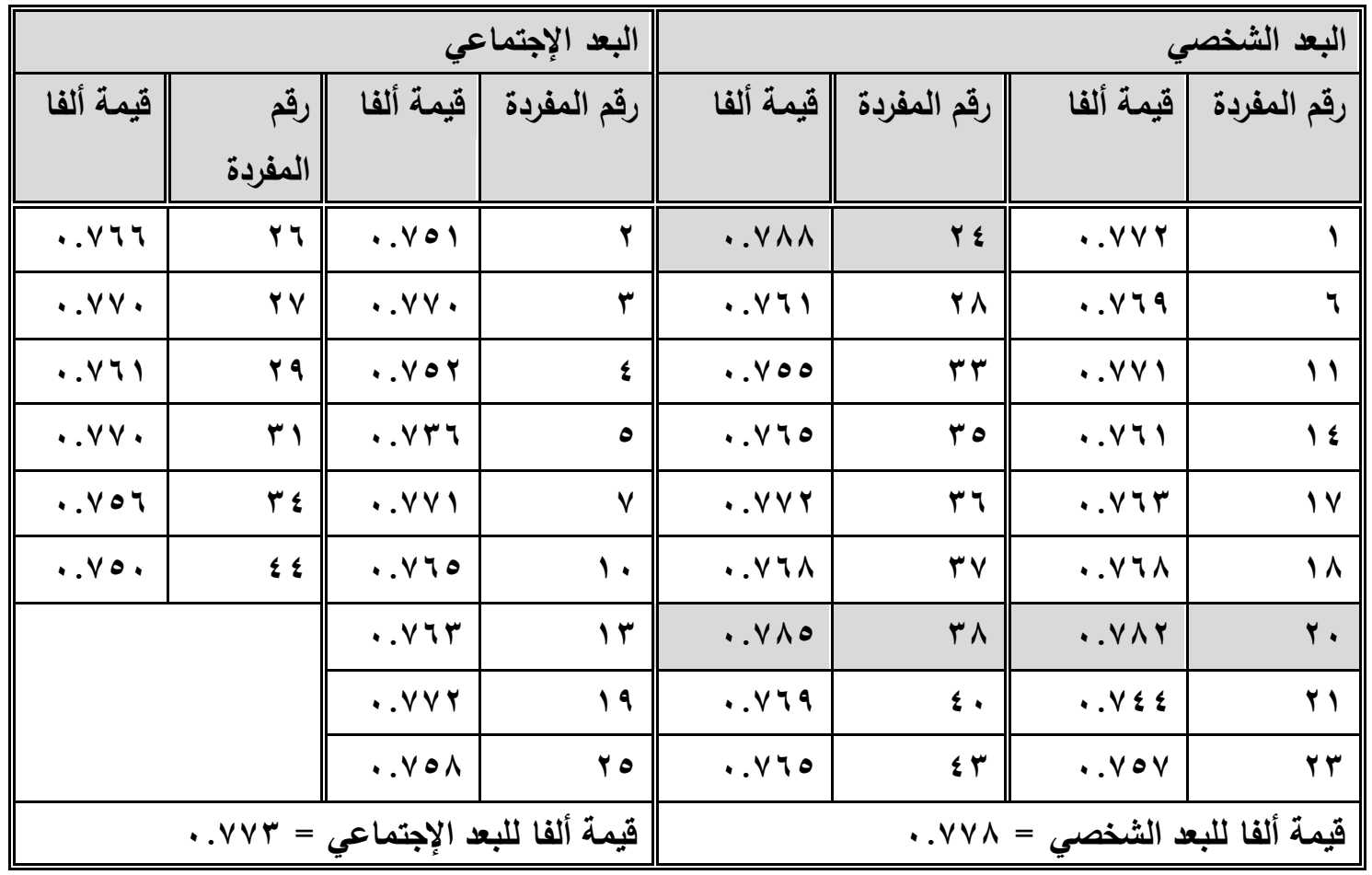

ويمقارنة قيمة ألفا الكلية لكل بُعد بقيمة ألفا بعد حذف كل مفردة من مفرداته من درجته الكلية؛

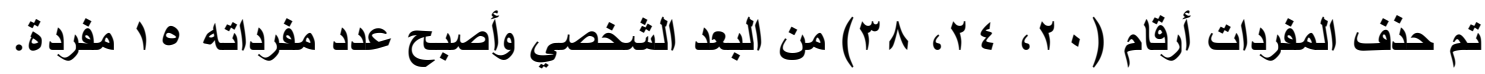
وأصبح عدد المفردات في الصورة النهائية للمقياس • ب مفردة، تثراوح درجات الأفراد عليها بين ه 1 و • r درجة، وتعبر الارجات المرتفعة عن تنافراً معرفياً عالياً. والجدول التالي يوضح توزيع تلك المفردات على الأبعاد. جدول (^) توزيع مفردات الصورة النهائية لمقياس التتافر المعرفي على أبعاده

\begin{tabular}{|c|c|c|}
\hline مفردات المقياس & عدد المفردات & أبعادهيع مفردات المقياس على \\
\hline 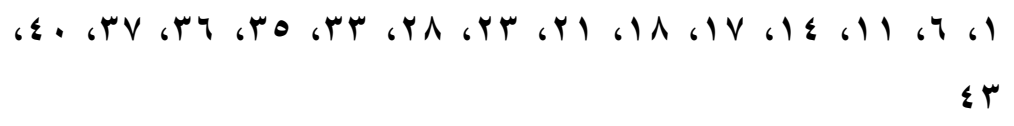 & 10 & البعد الشخصي \\
\hline 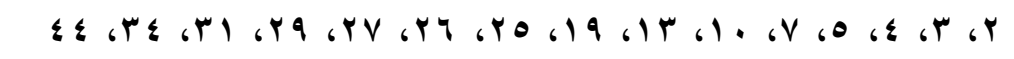 & 10 & البعد الإجتماعي \\
\hline
\end{tabular}
r. مقياس فاعلية الأات البحثية (إعداد/ الباحثة): 
هدف مقياس فاعلية الذات البحثية إلى التعرف على توقعات وتصورات طالب الداسات العليا

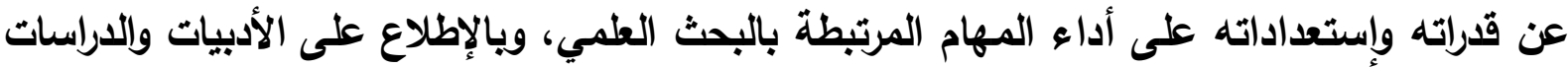
والبحوث السابقة، والمقاييس الأجنبية والعربية المستخدمة لقياس فاعلية الذات. ومنها على سبيل

( ) مقياس فاعلية الذات البحثية الأي أعده كلاً من (Bieschke, Bishop, \& Garcia, 1996) والمكون من به عنصراً لقياس قدرة الفرد المدركة على أداء مختلف السلوكيات المرتبطة بالبحث.

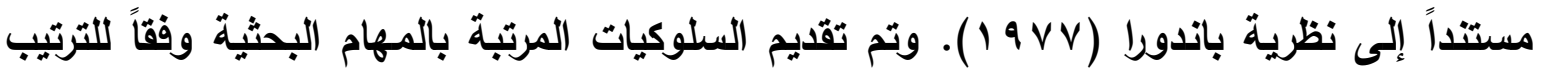

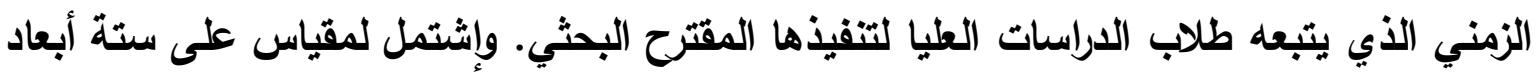

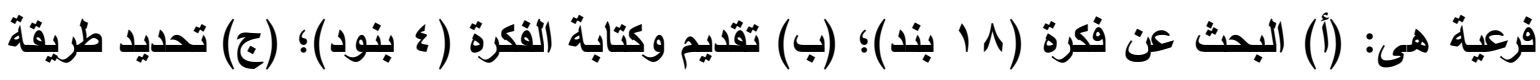

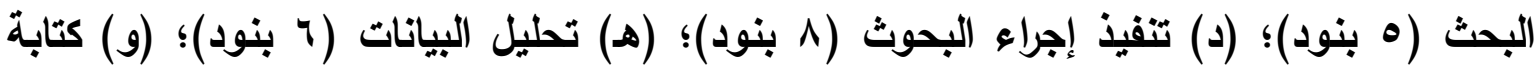

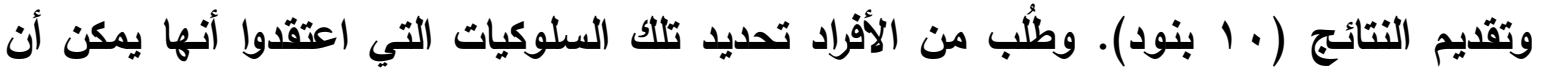
تؤديها في ذللك الوقت، ثم طُب منهم وضع رقم في عمود نقاط القوة يشير إلى درجة الثقة التي

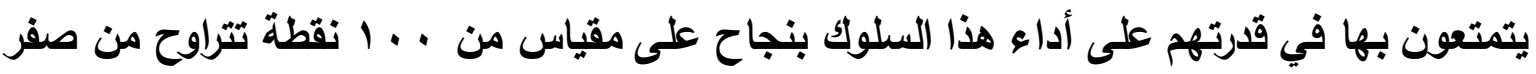
(عدم الثقة) إلى ، . . 1 (ثقة كاملة).

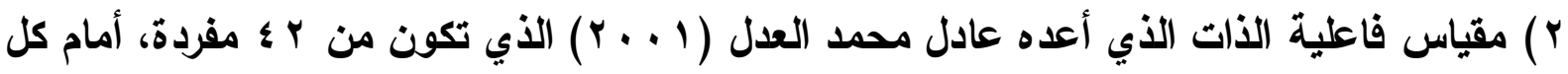

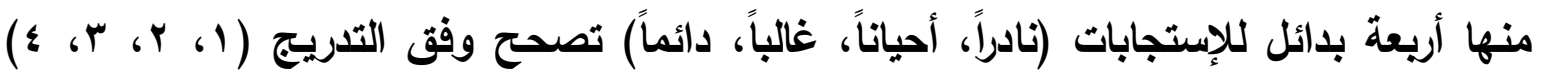

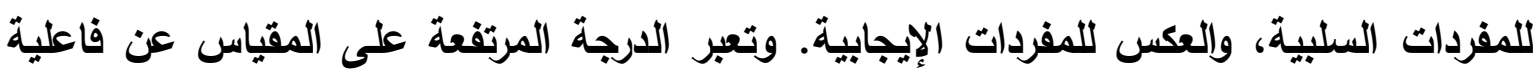
ذات عالية.

Büyüköztürk, Atalay, Sozgun, \& م مقياس فاعلية الذات البحثية الذي أعده كلاً من Kebapçı, 2011

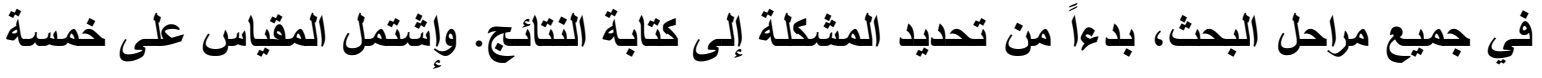

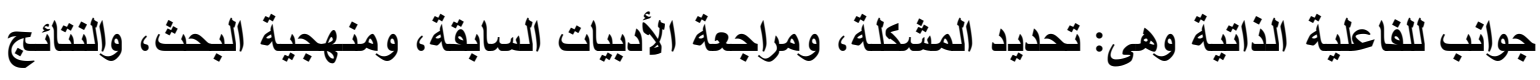

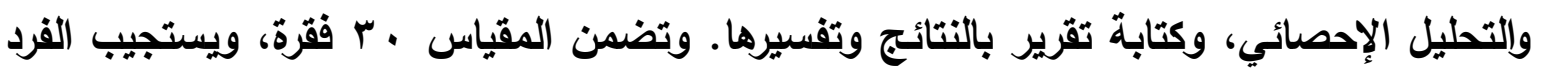

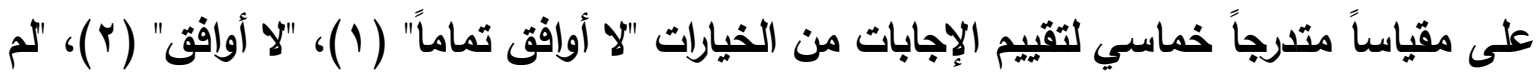

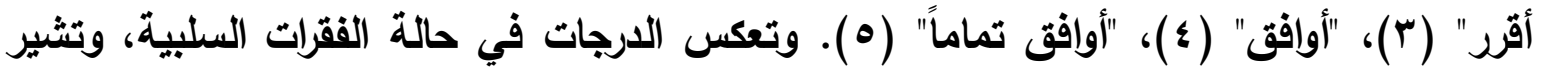

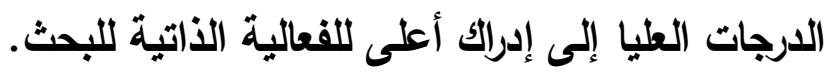

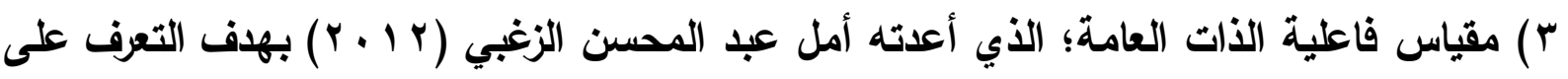

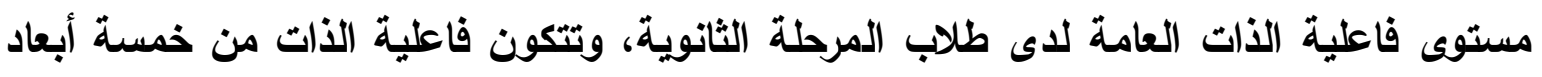

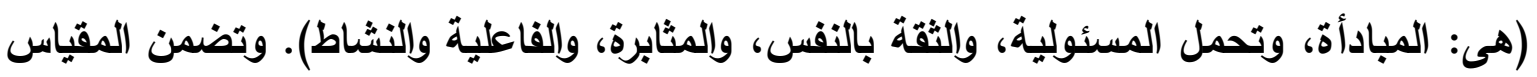




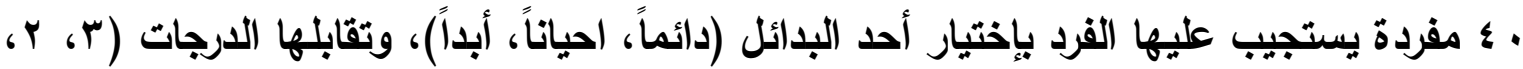
( ) على الترتيب.

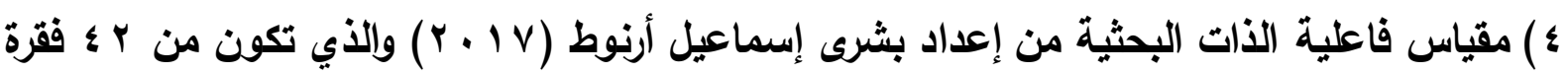
موزعة بالتساوي على سبعة أبعاد فرعية (وهى: توقع التجاح في المقرات، توقع القدرة على إختيار مشكلة البحث وإعداد مقترح لبحثها، توقع النجاح في عرض المقترح البحثي في السيمينار، القدرة على جمع الأدبيات التظرية لموضوع البحث، فاعلية إختيار التصميم المنهجي المناسب وإختيار الأدوات الملائمة لجمع البيانات، كفاءة جمع البيانات وتحليلها وتفسيرها وتقديم المقترحات والتوصيات، توقع القدرة على عرض نتائج الرسالة بعد الإنتهاء منها في المناقشة العلنية والردود على إستفسارات المناقشين)، ويتم الإجابة على بنود المقياس بإختيار أحد البدائل الخمسة (تنطبق تماماً، تنطبق، تتطبق إلى حد ما، لا تنطبق، لا تتطبق إطلاقًا) وتأخذ العبارات الإيجابية الدرجات

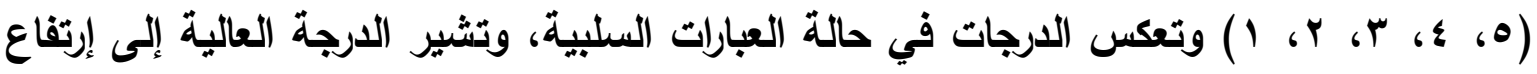
فاعلية الذات البحثية لاى المستجيب.

\section{وصف الصورة الأولية لمقياس فاعلية الثنات البحثيةدا:}

تكونت الصورة الأولية للمقياس من هب فقرة، تصف بصورة لفظية أحد مواقف أو أنشطة أو مهام البحث العلمي وتصور الفرد عن قدرته على إنجازها، وتوزع فقرات المقياس على ثلاثة أبعاد (المبادأة والمثابرة · ا فقرات، تحمل المسئولية البحثية ال 1 فقرة، الثقة بالنفس \& 1 فقرة). ويستجيب الطالب على فقرات المقياس بإختيار أحد البدائل وفقاً لطريقة ليكرت، حيث يوجد أمام كل فقرة ثلاث بدائل للإجابـة (تنطبق دائماً، تنطبق غالباً، تنطبق أحياناً، تنطبق نادراً، لا تتطبق أبداً)، وعند تصحيح المقياس يعطي الطالب درجة للبديل (0، ع، ب، Y، 1 ) على الترتيب. وتثير الارجات المرتفعة إلى تصورات عالية للفرد عن إنجازاته.

\section{التحقق من الثصائص السيكومتزية لامقياساس}

أولاً: صدق محتوى مقياس فاعلية الذات البحثية: عرضت الصورة الأولية للمقياس على عدد من المحكمين في مجال علم النفس؛ للتحقق من صدق المحتوى، وإبداء الرأي حول مدى إنتماء كل فقرة بالبعد الفرعي الذي إنتمت إليه، ومدى وضوح صياغة الفقرات.

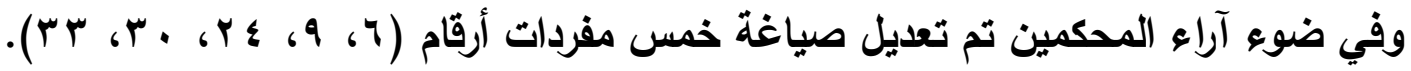
ثانياً: الصدق العاملي التوكيدي: تم إجراء التحليل العاملي التوكيدي لمقياس فاعلية الأت البحثية، وإختبرت ثلاثة أبعاد "المتغيرات الكامنة"، وقيم تشبعها على متغير كامن واحد "الارجة الكلية لمقياس فاعلية الأات البحثية". والجدول التالي يبين مصفوفة معاملات الإرتباط بين الأبعاد الثلاثة، وكذلك معامل إرتباط بيرسون بين درجة كل بعد والارجة الكلية للمقياس: 
جدول (9) معاملات الإرتباط بين درجة كل بعد والارجة الكلية لمقياس فاعلية الأت البحثية

\begin{tabular}{|c|c|c|c|}
\hline الثقة بالنفس & تحمل لمسئولية البحثية & المبادأة والمثابرة & الأبعاد \\
\hline & & $1 \ldots$ & المبادأة والمثابرة \\
\hline & $1 \ldots$ & $* .717$ & تحمل لمسئولية البحثية \\
\hline $1 \ldots$ & *. . . TrV & $* . .01 \leq$ & الثقة بالتفس \\
\hline$* . . \wedge \wedge 1$ & *. . ค ษ & $* \cdot . \Lambda \cdot r$ & الارجة الكلية للمقياس \\
\hline
\end{tabular}

$0 .=\dot{0}$

... دال عi

ويتضح من نتائج الجدول السابث أن جميع معاملات الإزتباط للأبعاد بالارجة الكلية لمقياس

فاعلية الذات البحثية دالة، وعليه فإن المقياس يتمتع بصدق بنائي مناسب. كما خضعت هذه المصفوفة للتحليل العاملي التوكيدي، وكاتت النتائج كما بالجدول التالي:

جدول ( • 1) نتائج التحليل العاملي التوكيدي للأبعاد الثلاثة في مقياس فاعلية الأت البحثية

\begin{tabular}{|c|c|c|c|c|}
\hline معامل الثبات & قود قلالتها & التقدير التشبع المعياري & "التشبع بالعامل الكامن & فاعلية الذات البحثية \\
\hline..$\leqslant 9 V$ & $* 0.1 \cdot r$ & $.1 \mathrm{\mu}$ & $\cdot v \cdot \theta$ & المبادأة والمثابرة \\
\hline . . & $* ฯ . \leqslant \leqslant 0$ & צו & $. \wedge \vee \leq$ & المسئولية \\
\hline . orr & *o.rq. &. $.1 r \Lambda$ &.$v r q$ & البقةية بالفس \\
\hline
\end{tabular}

$$
(\bullet \cdot=\dot{0})
$$

* دالة عند 1 (...

ومن الجدول السابق يتضح أن تثبع أبعاد المقياس بعامل كامن واحد، وهو الدرجة الكلية للمقياس، ويوضح الثكل التالي المسار التخطيطي لنموذج التحليل العاملي التوكيدي لمقياس فاعلية الذات البحثية.
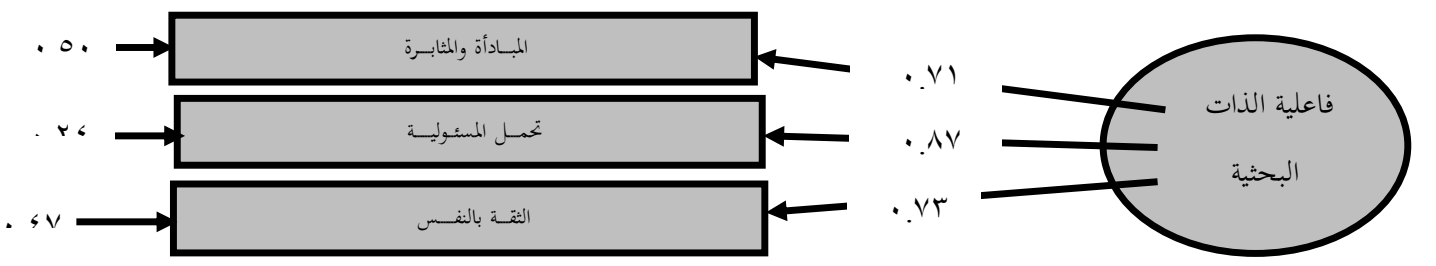

شكل (Y) المسار التخطيطي لنموذج التحليل العاملي التوكيدي لأبعاد مقياس فاعلية الأت البحثية التي تثبعت على عامل كامن واحد وقد حقق النموذج مؤشرات حسن المطابقة حيث كاتت قيمة كا` (X2) تساوي (صفر) عند درجات حرية (صفر)، وكاتت قيمة P تساوي (1) وهي قيمة غير دالة إحصائياً وتشير إلى مطابقة النموذج للبيانات. مما يشير إلى صدق المقياس بمستوى علمي مقبول، حيث تكون من ثلاثة أبعاد 
(المبادأة وإلمثابرة، وتحمل المسئولية، والثقة بالنفس) تثبعت جميعها مع متغير كامن واحد (الدرجة الكلية لمقياس فاعلية الذات البحثية).

ثالثاً: الاتساق الداخلي لمقياس فاعلية الذات البحثية:

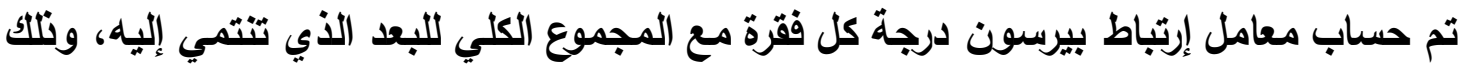
للتحقق من صدق الاتساق الا/خلي؛ كما هو موضح بالجدول التالي:

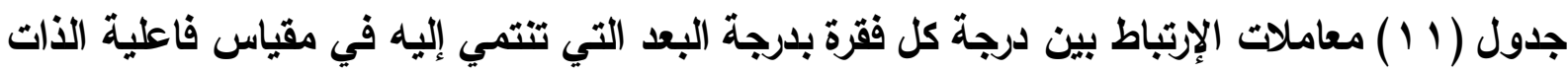

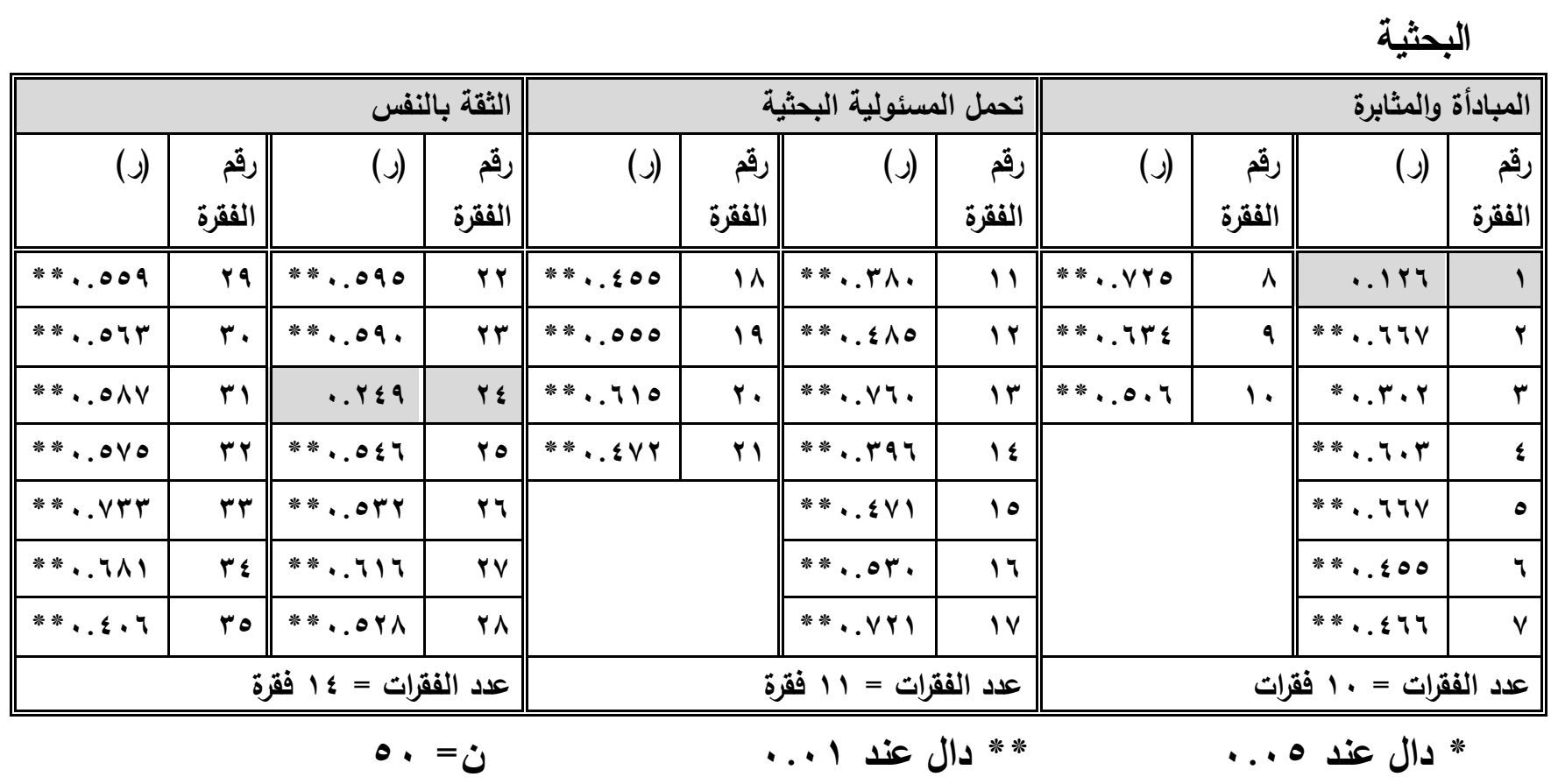

ومن خلال الجدول السابق يتضح أن معامل إرتباط الفقرات أرقام (1، ؛ ؟ب) بالبعد الذي تنتمي إليه غير دال، ويالتالي تم حذف هذه الفقرات. ثالثاً: ثبات مقياس فاعلية الذات البحثية: للتحقق من ثبات المقياس قامت الباحثة بما يلي: ا ـ ـ حساب الثبات بطريقة التجزئة النصفية: تم إستخدام طريقة التجزئة النصفية، لكل بُعد من أبعاد المقياس الثُلاثة على حلى حده ويوضح

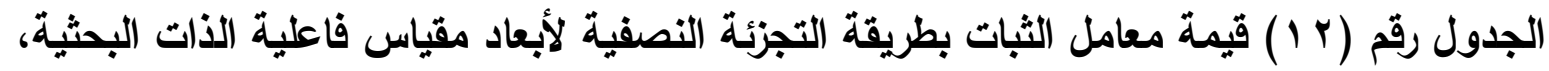
وقيمة معامل الثبات المصحح بطريقة سبيرمان براون. 
النموذج السبب للعلاقات بين القدرة على حل المشكلات الإحصائية وفاعلية الذات البحثية والتنافر المعرفي ووجهة الضبط لدى طلاب

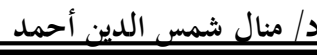

مرحلة الدراسات العليا بكلية التيبة.

جدول (Y I ) قيمة معامل الثبات بطريقة التجزئة النصفية لأبعاد مقياس فاعلية الأت البحثية (ن =

$(\bullet$.

\begin{tabular}{|c|c|c|c|}
\hline بُعد علد فقرات كل & 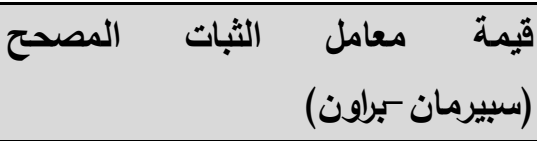 & 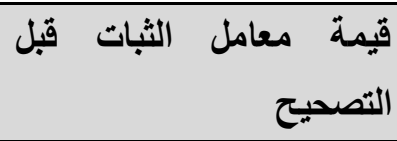 & الأبعاد \\
\hline 9 &.$v \vee v 1$ & $.7 r 0$ & المبادأة والمثثابرة \\
\hline 11 & $. V \bullet \leq$ & $\cdot .7 \cdot \varepsilon$ & تالبحثية \\
\hline $1 \pi$ & $\therefore \wedge \wedge \mu$ & $\because \vee q^{\prime}$ & الثقة بالنفس \\
\hline
\end{tabular}

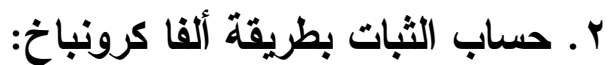

بحساب قيمة معامل الثبات بإستخدام طريقة ألفا، كانت قيمة معامل الثبات للمقياس ككل 1 ـ 9 . ، ، وهى قيمة معامل ثبات مقبولة علمياً. كما تم حساب معامل ثبات ألفا بعد استبعاد درجة كل فقرة من الدرجة الكلية للبعد الأي تتنمي إليه، كما هو موضح في الجدول التالي: جدول (r I) قيمة ألفا لمقياس فاعلية الأت البحثية "بعد استبعاد" درجة كل فقرة (ن = . •)

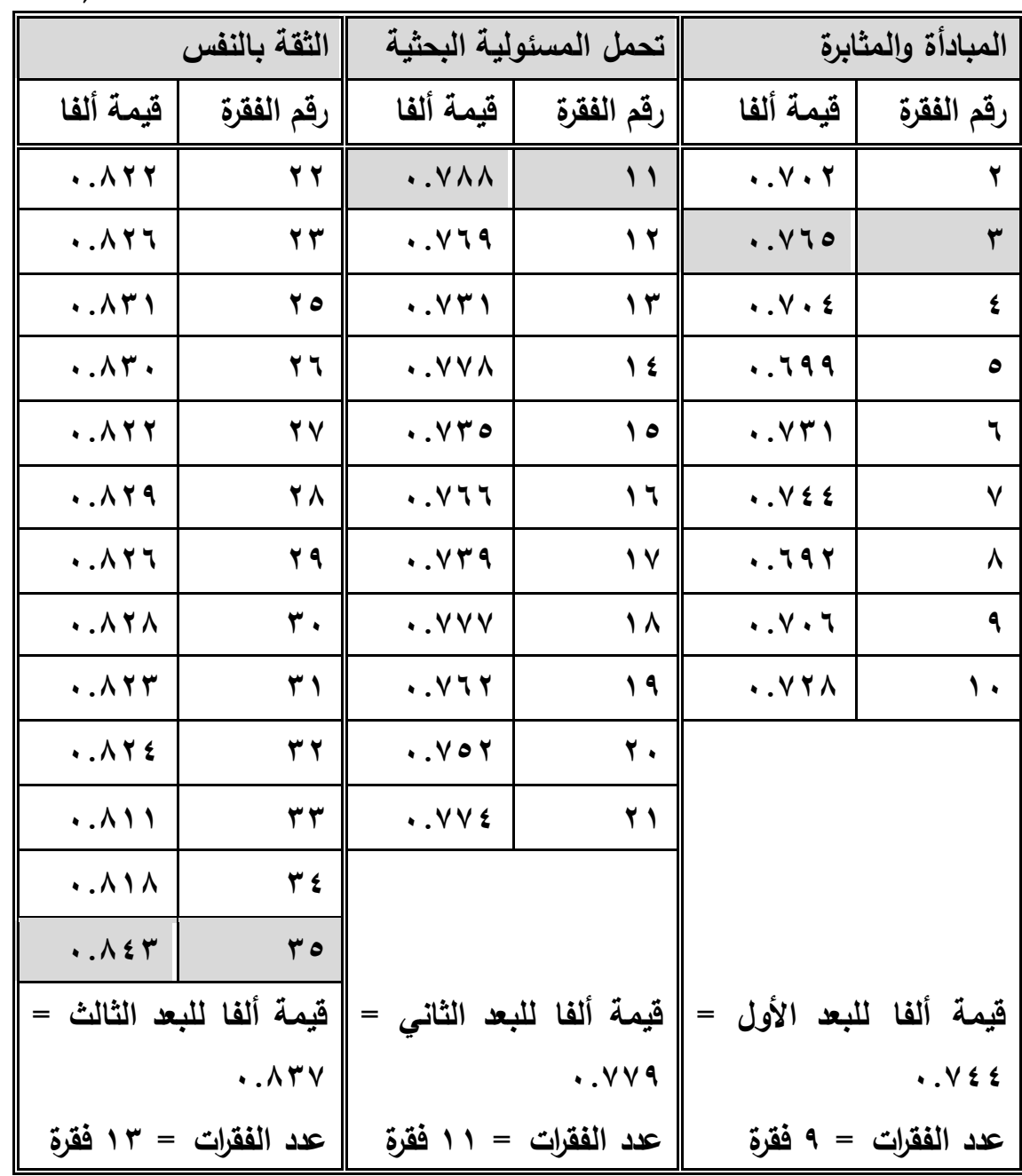


ويمقارنة قيمة ألفا الكلية بقيمة ألفا بعد حذف الفقرة من الارجة الكلية للبعد؛ تم حذف ثلاث

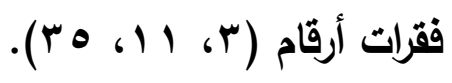

ووفقاً لما سبق أصبح عدد الفقرات في الصورة النهائية للمقياس ، ب فقرة. وتتراوح درجات الأفراد على المقياس بين ( • - . ( ))، وتعبر الارجات العالية عن فاعلي ذات عالية، في حين تعبر الارجات المنخفضة عن تدني تصور الفرد عن فاعليته البحثية. والجدول التالي يوضح توزيع فقرات مقياس فاعلية الذات البحثية (وعددهم ، ب فقرة) في صورته النهائية على الأبعاد الثلاثة. جدول (ع ا ) توزيع الفقرات على أبعاد مقياس فاعلية الذات البحثية

\begin{tabular}{|c|c|c|}
\hline 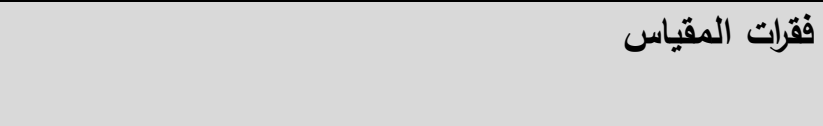 & عدد الفقرات & الثلاثة توزيع فقرات المقياس على الأبعاد \\
\hline 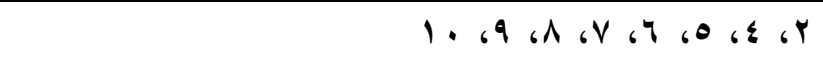 & $\wedge$ & المبادأة والمثابرة \\
\hline 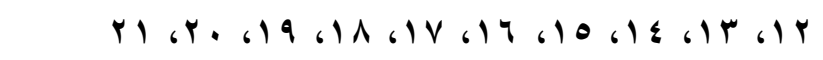 & 1. & تحمل المسئولية البحثية \\
\hline $\begin{array}{r}\text { \& } \\
\text { }\end{array}$ & ir & الثقة بالنفس \\
\hline
\end{tabular}

ع. مقياس وجهة الضبط "داخلي - خارجي":

وصف المقيساس

إستخدمت الباحثة مقياس وجهة الضبط الذي أعده علاء الدين أحمد كفافي ( Y A I )، ويتكون المقياس من r T فقرة؛ تتضمن كل منها عبارتين (أ، ب) تشير إحداهما إلى الوجهة الداخلية في الضبط، بينما تشير الأخرى إلى وجهة الضبط الخارجية. بالإضافة إلى ست فقرات دخلية حتى لا يكشف المستجيب الهدف من المقياس وتقليل إحتمال ظهور الإستعدادات للإستجابة بصورة معينة، ويتم تتاول قضايا عامة في هذه الفقرات الاخيلة مثل دور كل من الوراثة والبيئة في تفسير سلوك الفرد. وعلى المستجيب أن يقرأ العبارتين معاً، ثم يختار إحداهما التي تتفق مع وجهة نظره، وإذا كان موافقاً على العبارتين يختار أكثرهما قبولاً لديه. ويحصل الفرد على درجة واحدة إذا إختار العبارة التي تعبر عن وجهة الضبط الخارجي، ويحصل على صفر إذا إختار العبارة التي تعبر عن وجهة الضبط الداخلي. ويتم حساب الارجة الكلية على المقياس التي تتراوح بين صفر (عدم وجود إتجاه خارجي) و r (إتجاه خارجي). ويصنف الفرد بأنه ذو وجهة ضبط داخلي إذا حصل على ثمان درجات فأقل، ويأنه ذو وجهة ضبط خارجي إذا حصل على تسع درجات فأكثر.

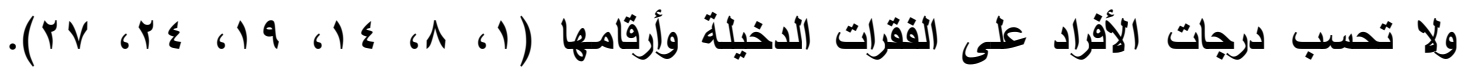
ويحصل المستجيب على درجة واحدة إذا إختار العبارة (أ) التي تعبر عن الوجهة الخارجية في كل من

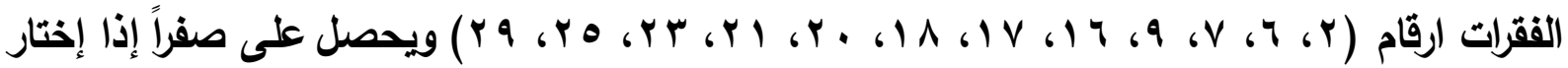


العبارة (ب) في هذه الفقرات. كما يحصل المستجيب على درجة واحدة إذا إختار الفقرة (ب) التي تشير

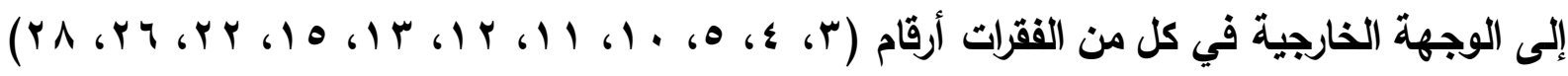
ويعطى صفراً إذا أجاب عليهم بإختيار العبارة (أ) في هذه الفقرات. التحقق من الخصائص السيكومترية لمقياس وجهة الضبط: - الاتساق الداخلي لمقياس وجهة الضبط: قام معد المقياس علاء الاين أحمد كفافي ( 9 ^ 1 ) بحساب صدقه الذاتي وهو الجذر التربيعي

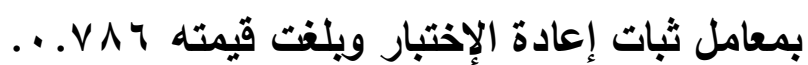
وفي البحث الحالي تم حساب معامل إرتباط بيرسون بين الفقرات والدرجة الكلية للمقياس، للتحقق من الصدق البنائي، كما هو موضح بالجدول التالي: جدول (0 1 ) معاملات إرتباط الققرات بالدرجة الكلية لمقياس وجهة الضبط

\begin{tabular}{|c|c|c|c|c|c|}
\hline (J) & الفقرة & (১) & الفقرة & (נ) & الفقرة \\
\hline$* . . \wedge \wedge$ & r) & *..rTV & 11 & $. r \leqslant 1$ & $r$ \\
\hline$* * \ldots 乞 \vee \wedge$ & YY & $* * . .00 \%$ & ir & $* . \mu \mid r$ & $r$ \\
\hline **.. & rr & $* * \ldots 7.1$ & 14 & ***. . & $\varepsilon$ \\
\hline *..r & ro & $* * . .0 \vee 9$ & 10 & $* \cdot . r \cdot T$ & 0 \\
\hline$* . r \circ q$ & Y & $* * \ldots \leqslant V V$ & 17 & $* . . Y q \leq$ & 7 \\
\hline$. .1 \leq 1$ & rı & $\cdot .1 \cdot \varepsilon$ & IV & $* . . M I V$ & V \\
\hline ***. . $\{\Psi \varepsilon$ & rq & $* * \ldots$ * . 90 & 11 & .0179 & 9 \\
\hline قرات = & فقرة & *..rT. & $r$. & *.r. & 1. \\
\hline
\end{tabular}
* دال عند ه....

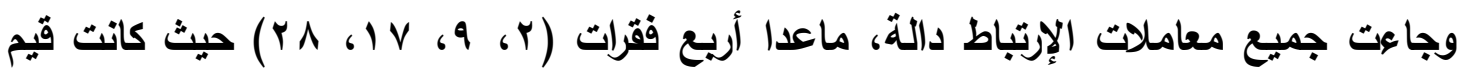
معاملات إرتباطها بالارجة الكلية للمقياس غير دالة، وتم حذف هذه الفقرات. ويذلك تعتبر فقرات المقياس صادقة لما وضعت لقياسه.

\section{- ثبات مقياس وجهة الضبط:}

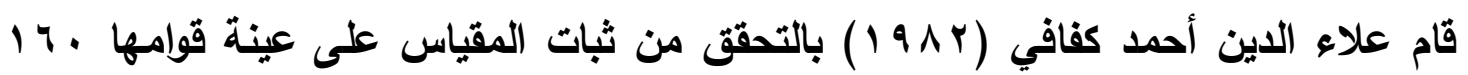
طالباً وطالبة، بحساب معامل الإستقرار بإعادة تطبيق المقياس بعد تطبيقه للمرة الأولى بفاصل زمني 7

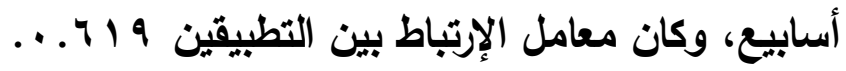
كما تم حساب الثبات بالتجزئة النصفية وكانت قيمة معامل الإرتباط بين نصفي الإختبار 1 ץ ه. . ومعامل الإرتباط المصحح بمعادلة سبيرمان براون 99 . . . . وتم حساب معامل الإرتباط بين 
مجموع درجات الفقرات الفردية واللارجة الكلية للمقياس وكاتت قيمته AVY. . . ، ومعامل إرتباط مجموع درجات الفقرات الزوجية بالدرجة الكلية للمقياس كاتت قيمته ^ ـ ^ـ . ، مما يشير لتمتع المقياس بلرجة ثبات مرتفعة.

وفي البحث الحالي تم حساب الثبات بطريقة التجزئة النصفية فكانت قيمة معامل الإرتباط بين

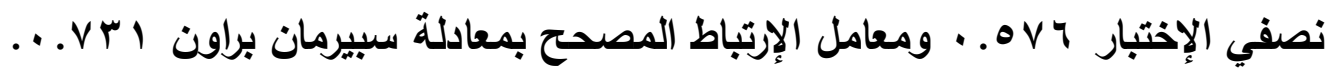
وتم حساب معامل الثبات ألفا كرونباخ للمقياس ككل ويلغت قيمته س Y V . . ، ومعامل ثبات ألفا بعد إستبعاد درجة كل فقرة من الارجة الكلية للمقياس، كما هو موضح في الجدول التالي: جدول (7 1) قيمة ألفا لمقياس وجهة الضبط "بعد استبعاد" درجة كل فقرة (ن = • •)

\begin{tabular}{|c|c|c|c|c|c|}
\hline قيمة ألفا & رقم & قيمة ألفا & رقم & قيمة ألفا & رقم \\
\hline. .791 & Yr & $. .79 \leq$ & $1 r$ & $\because V I V$ & $\mu$ \\
\hline.$V 1$. & $r$ &. $.79 r$ & Ir &.$v_{1}$ & $\varepsilon$ \\
\hline.$\vee \vee \wedge$ & ro &. .799 & 10 & .VYr & 0 \\
\hline.$V 10$ & rq &..$V \cdot V$ & 17 & . VYr & 7 \\
\hline$\cdots V \cdot q$ & pq & $\cdot . V \cdot \Lambda$ & 11 & . & V \\
\hline \multirow[t]{2}{*}{$19=$} & &.$V Y$. & $r$. &.$V I V$ & 1. \\
\hline & فقرة &..$V Y r$ & Y & . VY. & 11 \\
\hline
\end{tabular}

ويمقارنة قيمة ثبات ألفا للمقياس ككل (VYr. V . ) بقيمة ثبات ألفا بعد حذف الفقرة من الدرجة

الكلية للمقياس. وأصبح عدد المفردات في الصورة التهائية للمقياس 9 أمفردة. (د) (د) إجراءات البحث: (1)

() تم إختيار عينة البحث بطريقة عشوائية وتكونت من من • 1 إلباً وطالبة من طلاب الدراسات العليا (المقيدين بالدبلوم الخاص، والماجستير، والدكتوراه) بكلية التربية بالعام الجامعي ^ 1 ـ ب $\cdot r^{2} \cdot 19$

r) تم إعداد أدوات البحث، والتحقق من الخصائص السيكومترية لها على عينة قوامها م • طالباً وطالة. r) تم تطبيق أدوات البحث التطبيق داخل معامل عم النفس بكلية التربية في الأوقات المناسبة للطلاب، وتم البدء بمقياس القدرة على حل المشكلات الإحصائية، ثم تطبيق باقي الأدوات بفاصل زمني قصيرة في نفس الجلسة أو في جلسة أخرى. ع) إجراء المعالجات الإحصائية بإستخدام الحزمة الإحصائية في العلوم النفية والإجتماعية SPSS، ويرنامج ليزرال Lisrel 8.8 


\section{(ه) الأساليب الإحصائية المستخدمة:}

ا ـ الإحصاءات الوصفية (المتوسط ، والإنحراف المعياري، والإلتواء) لتحديد طييعة توزيع المتغيرات.

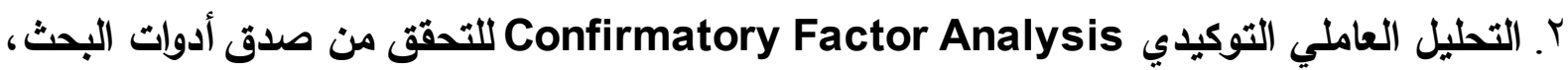

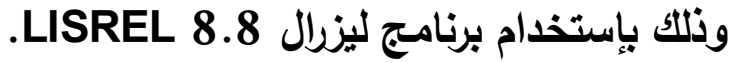

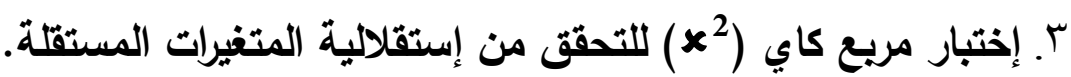

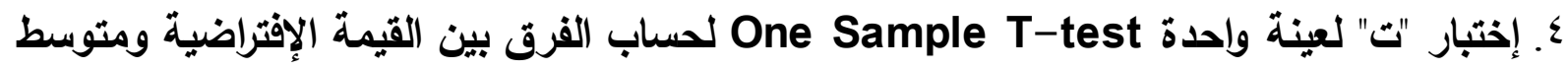
درجات الطلاب في متفيرات البحث.

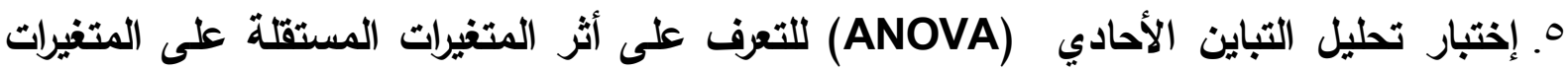
التابعة، والتعرف على التأثيرات التفاعلية لمستويات كل متغير مستقل عبر المتغير التابع.

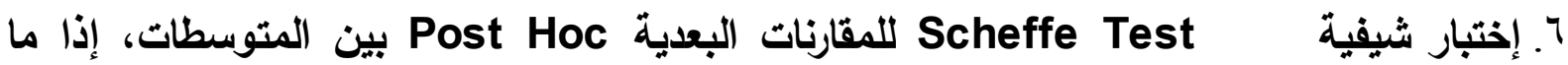
أسفر تحليل التباين عن وجود فروق بين المجموعات، وكان أحد المتغيرات المستقلة يحتوي على أكثر من مستويين، أو في حالة دلالة الفروق بين التفاعلات الثثائية بين المتفيرات المستقلة.

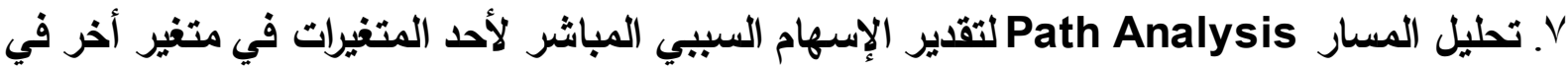
موقف غير تجريبي، وذلك بإستخدام برنامج 8.8 مائر الإسهار

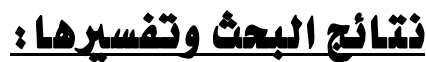

تم إيجاد مؤشرات الإحصاء الوصفي "المتوسطات والإنحرافات المعيارية ومعاملات الإلتواء" لجميع المتغيرات في عينة الأساسية للوقوف علي طبيعتها، كما هو موضح باءت الجدول التالي:

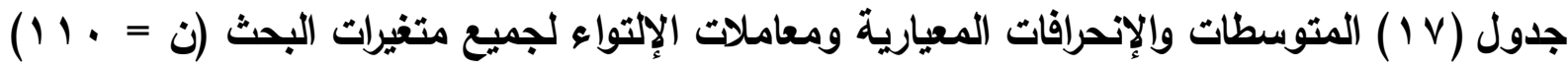

\begin{tabular}{|c|c|c|c|}
\hline معامل الإلتواء & المعياري & المتوسط & المتغيرات \\
\hline. .79 & $\varepsilon \ldots 1$ & V.Ar & المشكلات $\quad$ القدرة \\
\hline $.0 r$ & $17.4 \mathrm{~V}$ & AT.Vo & التتافر المعرفي \\
\hline$\cdot . \wedge 9-$ & 10.11 & $\begin{array}{r}110 . r \\
0\end{array}$ & فاعلية الذات البحثية \\
\hline$\cdots \varepsilon$ & r.rA & $\Lambda .0 \mathrm{~V}$ & وجهة الضبط \\
\hline
\end{tabular}

ومن الجدول السابق يتضح أن معاملات الإلتواء للارجات الكلية لمتغيرات البحث تتراوح ما بين -19. . . و 99 . . مما يال علي إعتدالية توزيع العينة. 


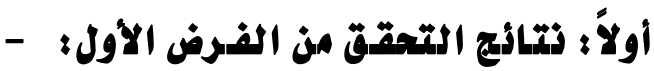

ينص الفرض الأول على "مستوى التتافر المعرفي لدى طلاب الدراسات العليا بكلية التربية جامعة قتاة السويس متوسطاً"، وللتحقق من صحة هذا الفرض ولمعرفة مستوى التنافر المعرفي لدى طلاب الدراسات العليا بكلية التربية فقد تم تقسيم مدى درجات الطلاب على المقياس إلى ثلاثة مستويات متساوية حسب المعيار :

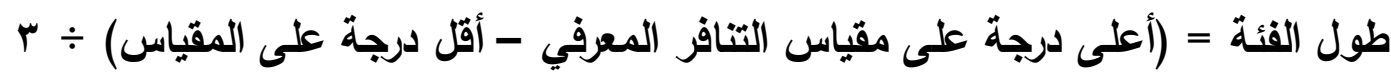
rq.r $r=r \div(\varepsilon q-1$ ro $)=$

حيث أظهرث النتائج أن أقل درجة حصل عليها الطلاب على مقياس التنافر المعرفي هى ( آ ؛

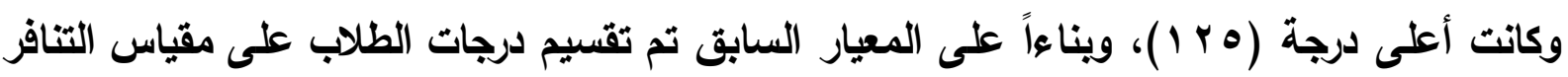
المعرفي كما بلي:

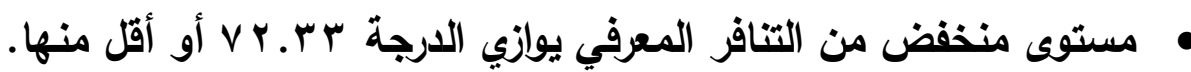

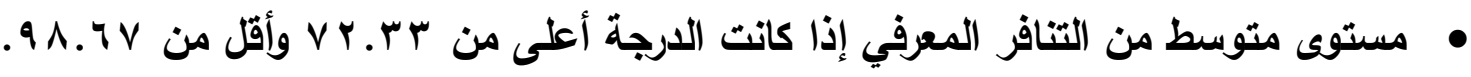
• مستوى مرتفع من التنافر المعرفي إذا حصل الطالب على الارجة A A .7 V أو أعلى منها. كما تم حساب التكرارات والنسب المئوية لمستويات التتافر المعرفي لاى طلاب الدراسات العليا، كما هو مبين بالجدول التالي:

جدول (1 1 ) التكرارات والنسب المئوية لمستويات التتافر المعرفي لاى عينة البحث (ن = 1 1 )

\begin{tabular}{|c|c|c|c|c|c|c|c|c|c|c|c|c|}
\hline كتوراه & طلاب ا & \multicolumn{2}{|c|}{ طلاب الماجستير } & \multicolumn{2}{|c|}{ طلاب } & \multicolumn{2}{|c|}{ الطلاب الإناث } & \multicolumn{2}{|c|}{ الطلاب الذكور } & \multicolumn{2}{|c|}{ للعينة ككل } & \multirow[t]{2}{*}{ مستوى } \\
\hline النسبة & التكرار & النسبة & التكرار & النسبة & التكرار & النسبة & التكرار & النسبة & التكرار & النسبة & التكرار & \\
\hline$\% r$. & $r$ & $\% r$. & 1. & $\%$ \% & 17 & $\%$ \% & rr & $\%$ \&. & 7 & \%หч. & rq & منخفض \\
\hline$\%$ \%r.r & 11 & 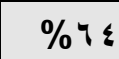 & $r r$ & \%тr.r & $r \wedge$ & \%ч4. & זי & $\% \circ r . r$ & $\wedge$ & $\%$ \% . .० & VI & متوسط \\
\hline$\% 7 . V$ & 1 & $\% 17$ & $\wedge$ & $\%$ r.r & 1 & $\% 9.0$ & 9 & $\%$ \%. & 1 & $\% 9.1$ & 1. & مرتفع \\
\hline$\% 1 \ldots$ & 10 & $\% 1 \ldots$ & o. & $\% 1 \ldots$ & $\leqslant 0$ & $\% 1 \ldots$ & 90 & $\% 1 \ldots$ & 10 & $\% 1 \ldots$ & 11. & ن \\
\hline
\end{tabular}

ويتضح من الجدول السابق أن أفراد العينة من طلاب الدراسات العليا بكلية التربية يعانون من

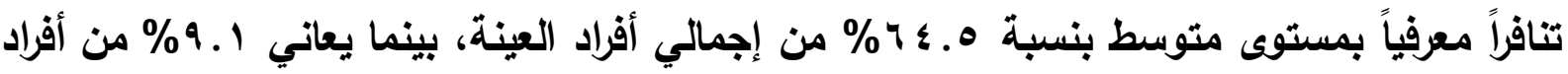
العينة من مستوى عالي من التنافر المعرفي، في حين يعاني ؟ ـ ؟ ٪ من مستوى منخفضاً من التنافر المعرفي.

وتثير النتائج الموضحة بالجدول السابق أن مستوى التنافر المعرفي لاى الطلاب الأكور والإناث متوسطاً، ولكن كاتت نسبة بين الطالبات الإناث بنسبة r. 7\%\% بينما كانت لدى الطلاب الأكور بنسبة r.\%or. 
كما يلاحظ أن طلاب الدراسات الطيا بالدبلوم الخاص والماجستير والدكتوراه يعانون تنافراً

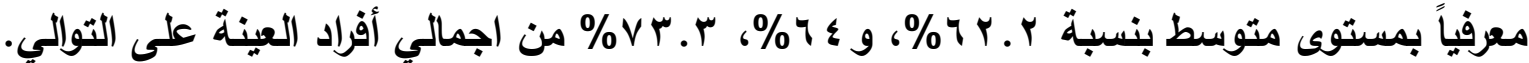

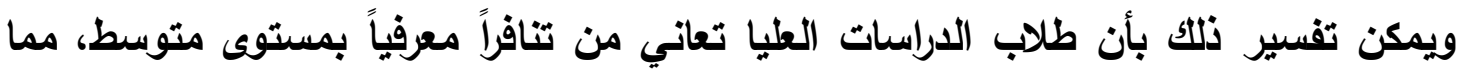

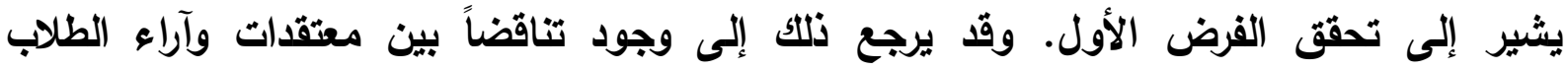

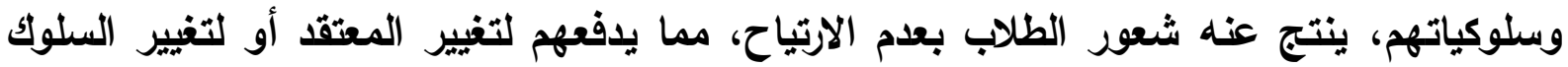

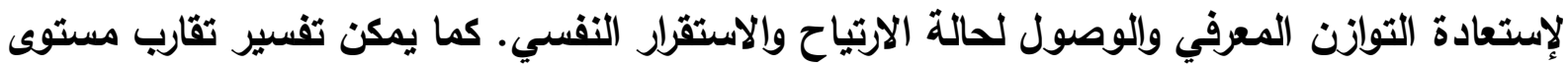

التنافر المعرفي لدى طلاب الابلوم الخاص والماجستير والدكتوراه نظراً لتشافه الخلفية العلمية لهم.

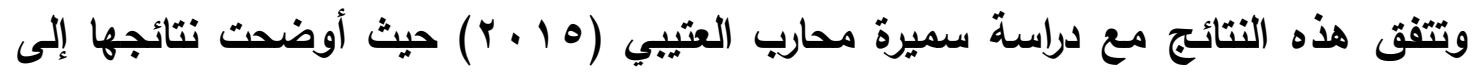
مستوى متوسط من التتافر المعرفي لدى طلاب جامعة أم القرى بمكة المكرمة. ودراسة عمر عطا الله

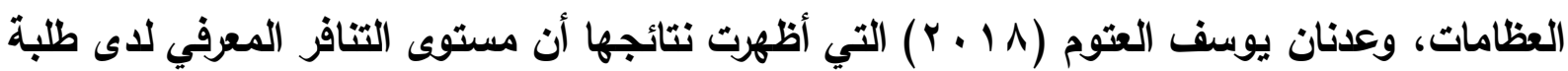
جامعة اليرموك كان متوسطاً.

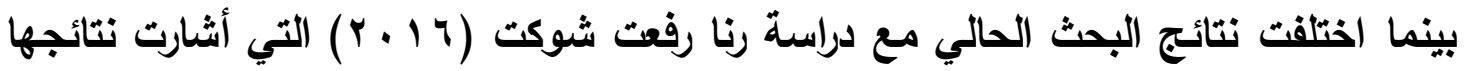
إلى أن طلاب كلية التربية بالجامعة المستنصرية ببغداد ليس لايها تنافراً معرفياً.

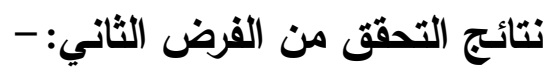
ينص الفرض الثاني على "مستوى فاعلية الذات البحثية لاى طلاب الدراسات العليا بكلية التربية جامعة قتاة السويس منخفضاً"، وللتحقق من صحة هذا الفرض الفرض ولمعرفة مستوى فاعلية

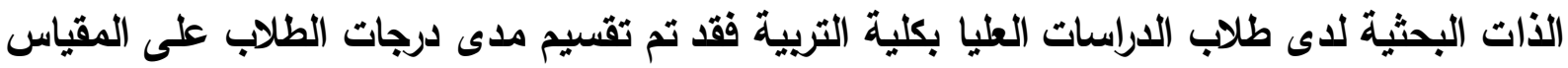
إلى ثلاثة مستويات متساوية حسب المعيار:

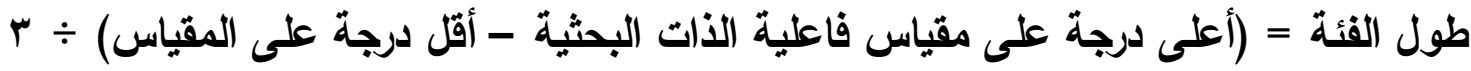
rч.rr = r $\div(r r-1 \leqslant 1)=$ حيث أظهرت النتائج أن أقل درجة حصل عليها الطلاب على مقياس فاعلية الأات البحثية هى

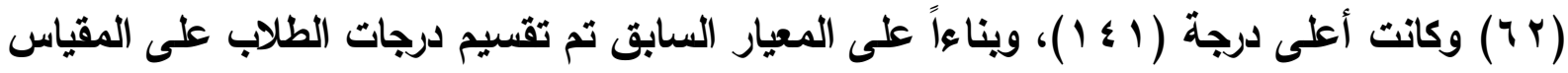

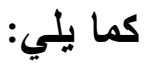

• مستوى منذفض من فاعلية الذات البحثية مساوياً الدرجة بـ بـ أو أقل منها.

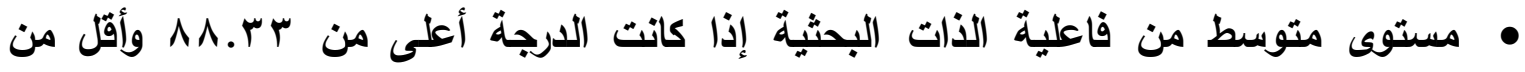
$.11 \leqslant .7 \mathrm{~V}$ • مستوى مرتفع من فاعلية الذات البحثية إذا حصل الطالب على الدرجة VIV. 11 أو أو أعلى منها. 
ويحساب التكرارات والنسب المئوية لمستويات فاعلية الذات البحثية لاى طلاب الاراسات العليا،

$$
\text { جاعت النتائج كما هو مبين بالجدول التالي: }
$$

جدول (9 1 ) التكرارات والنسب المئوية لمستويات فاعلية الذات البحثية لاى عينة البحث

\begin{tabular}{|c|c|c|c|c|c|c|c|c|c|c|c|c|}
\hline \multicolumn{2}{|c|}{ طلاب الاكتوراه } & \multicolumn{2}{|c|}{ طلاب الماجستير } & \multicolumn{2}{|c|}{ طلاب الدبلوم } & \multicolumn{2}{|c|}{ الطالبات الإناث } & \multicolumn{2}{|c|}{ الطلاب الذكور } & \multicolumn{2}{|c|}{ للعينة ككل } & \multirow{2}{*}{ الألاعلية } \\
\hline النسبة & التكرار & النسبة & التكرار & النسبة & التكرار & النسبة & التكرار & النسبة & التكرار & النسبة & ا التكرار & \\
\hline- & - & $\% 4$ & $r$ & $\%$ \%. & r & $\% 0 . r$ & 0 & - & - & $\% \leqslant .0$ & 0 & منخفض \\
\hline \%чч.จ & $\varepsilon$ & $\%$ r. & 10 & $\% \leq r . r$ & 19 & $\% r \varepsilon . v$ & rr & \%rr.r & ○ & $\% r \leqslant .0$ & rᄉ & متوسط \\
\hline$\% \vee r . r$ & 11 & $\% ч \leq$ & rr & $\%$ \%.r. & $r \leq$ & $\% 4$. & ov & $74 . V$ & 1. & $\% 7.9$ & TV & مرتفع \\
\hline$\% 1 \ldots$ & 10 & $\% 1 \ldots$ & 0 . & $\% 1 \ldots$ & $\leqslant 0$ & $\% 1 \ldots$ & 90 & $\% 1 \ldots$ & 10 & $\% 1 \ldots$ & 11. & ن \\
\hline
\end{tabular}

وأشارت النتائج إلى عدم تحقق الفرض الثاني، فيتضح من الجدول السابق أن أفراد العينة من طلاب الدراسات العليا بكلية التربية لايهم معتقدات وتصورات حول أمكانياتهم للإنتاجية البحثية وأداء مهامهم البحثية بمستوى مرتفع بنسبة 9. . 7\% من إجمالي أفراد العينة، في حين أن ه. ع ب\% من أفراد العينة يقيمون فاعليتهم البحثية بمستوى متوسط، بينما يرى هـ ؛ \% من الطلاب أن إستعداداتهم لإنجاز المهام المرتبطة بالبحث العلمي بمستوى منخفضاً. ويمكن تفسير ذلك بأن طلاب الدراسات العليا لايهم توقعات إيجابية عن إستعداداتهم وإمكاناتهم على أداء مهام البحث العلمي، وتحمل المسئولية البحثية، وتصوراتهم عن قدراتهم لمواجهة الصعويات، والمثابرة لإنجاز البحث العلمي في موعده. ويعد ذلك مؤشراً على وعي طلاب الاراسات العليا بكلية التربية بقدرهم على أداء المهام البحثية بنجاح وفي موي الوقت المحدد لها.

كما أشارت النتائج إلى وجود مستوى مرتفع من فاعلية الذات البحثية لاى طلاب الدراسات

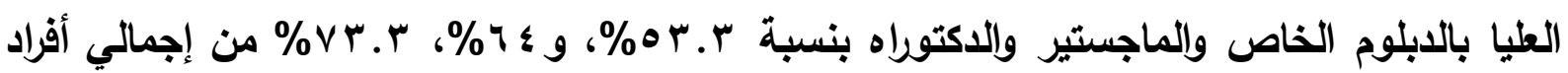
العينة على التوالي. أي أن فاعلية الذات البحثية لطلاب الاكتوراه أعلى من طلاب الابلوم الخاص والماجسير، فتزداد الفاعلية الذاتية لطلاب الدراسات العليا كلما زادت خبراتهم ومستوى دراستهم، ويكون الطالب أكثر تحملاً لمسئولية تعلمه وإجتهاده الأكاديمي، وقد يفسر ذلك في ضوء أن الظروف البيئية الجامعية تتيح للطلاب الفرصة الكافية لإكتشاف فاعليتهم الأتية في تحقيق أهدافهم البحثية.

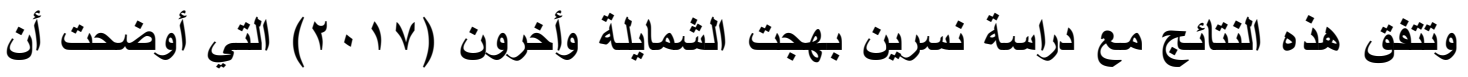
القاعلية الأتية لطلاب كلية الطب مرتفعة في كل الفرق الدراسية. وتختلف مع دراسة دراسة بشرى إسماعيل أرنوط ( V • P ) حيث أظهرت نتائجها إلى وجود مستوى منخفض من فاعلية الذات البحثية لدى طلاب الدراسات العليا في الارجة الكلية للمقياس وفي أبعاده (توقع النجاح في إختيار المشكلة، 
وتوقعاته عن امكانية نجاحه في عرض المقترح البحثي، والقدرة على جمع الأدبيات النظرية، وفاعلية إختيار التصميم المنهجي، وتوقع الفرد عن قدرته على عرض عند النتائج ومناقشتها).

$$
\text { نتائج التحقق من الفرض الثالث: - }
$$

ينص الفرض الثالث على "يتبنى طلاب الاراسات العليا بكلية التربية جامعة قناة السويس

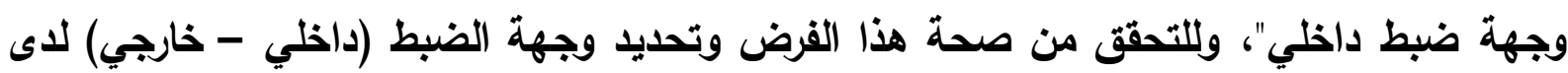

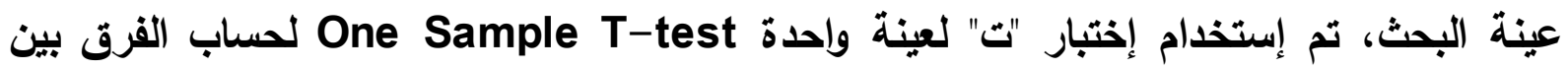
متوسط درجات الطلاب على مقياس وجهة الضبط والدرجة الإفتراضية (V)، كما هو موضح في الجدول

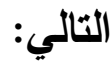
جدول (·r) نتائج إختبار (ت) بين المتوسط الفرضي ومتوسط الحسابي لوجهة الضبط لدى عينة

\begin{tabular}{|c|c|c|c|c|c|}
\hline قيمة (ت) & درجة الحرية & الإنحراف المعياري & المتوسط الحسابي & العدد & المتغير \\
\hline$* \varepsilon . \wedge \wedge \theta$ & 1.9 & r.rVV & $\Lambda .0 V T$ & 11. & العينة الكلية \\
\hline$* r .011$ & $\varepsilon \varepsilon$ & Y.977 & 1.004 & $\leqslant 0$ & طلاب الدبلوم الخاص \\
\hline *Y. & $\leqslant 9$ & r.vir & A.Ar. & 0 . & طلاب الماجستير \\
\hline.$\wedge 94$ & $1 \leqslant$ & r. \४ & V.A.. & 10 & طلاب الدكتوراه \\
\hline
\end{tabular}

$$
\begin{aligned}
& 11 \cdot=0 \\
& \text { " دال عند مستوى I... }
\end{aligned}
$$

ومن نتائج الجدول السابق يتبين أن المتوسط الحسابي لوجهة الضبط لاى طلاب الدراسات

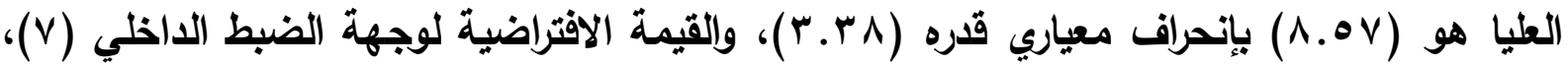

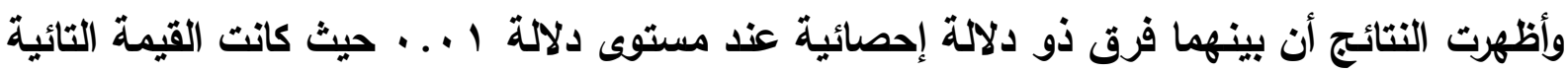

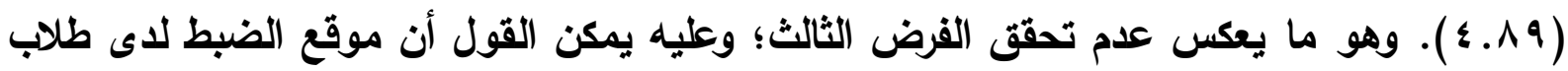

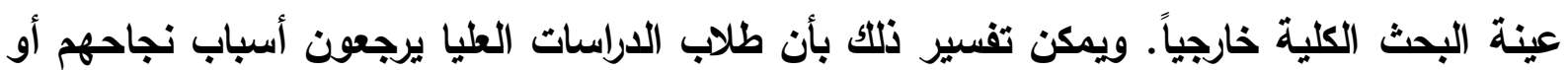

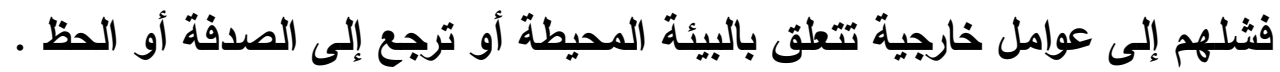
كما توجد فروق بين متوسطات درجات طلاب الدبلوم الخاص وطلاب الماجستير على مقياس

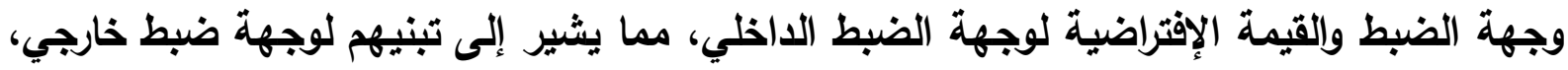

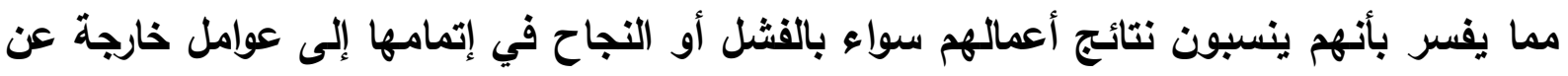
إرادتهم ولا ترتبط بما يبذلونه من جها بل ترجع إلى عوامل البيئة الخارجية والتيسيرات أو الصعويات

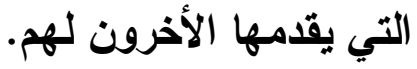
بينما يتحقق الفرض في يتبنى طلاب الاكتوراه لوجهة ضبط داخلي حيث أشارت النتائج لعدم

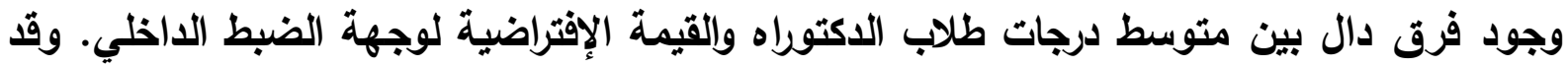


يعزى ذلك لإدراكهم لأهمية أن يكونوا مسئولين عن نتائج أعمالهم وأن هذه النتائج سواء كانت إيجابية أو سلبية ترجع إلى جهودهم وقدراتهم أكثر مما تعود إلى عوامل خارجية كالقدر أو الحظ أو الصدفية.

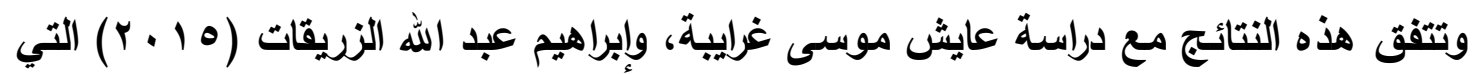

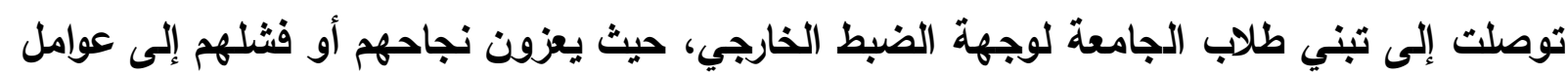
خارجية.

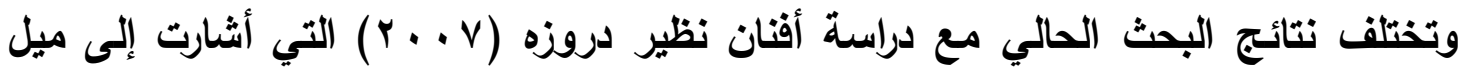
طلاب الاراسات العليا بكلية التربية في جامعة النجاح الوطنية بفلسطين إلى الإنضبط الداخلي أكثر منه دانه

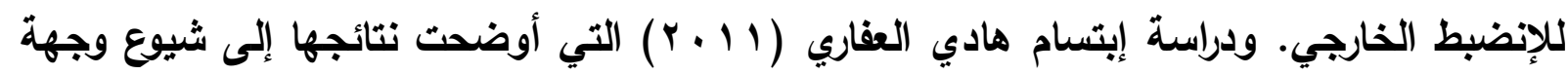

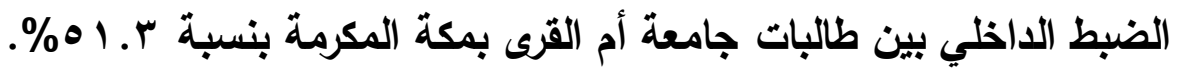
نتائج التحقق من الفرض الرابع: ينص الفرض الرابع على "توجد فروق دالة في القدرة على حل المشكلات الإحصائية لدى طلاب الدراسات العليا بكلية التريبة جامعة قناة السويس تعزى لإختلاف كل من المستوى الدراسي (د. لخاص، وماجستير، ودكتوراه) والتخصص (علم نفس، وتربية خاصة، وصحة نفسية) والتفاعل بينهما".

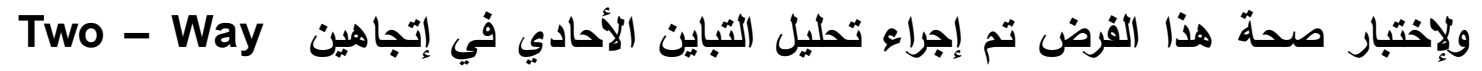
ANOVA والتأثيرات التفاعلية بينهما على المتغير التابع (القدرة على حل المشكلات الإحصائية).

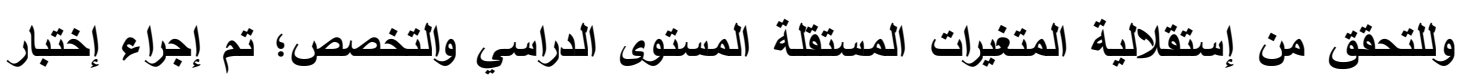
مريع كاي (x²). والجدول التالي يوضح توزيع أفراد عينة البحث حسب المتغيرين والقيم المتوقعة حسب إختبار الإستقلالية.

جدول (Y) توزيع بيانات العينة عبر المتفيرين المستوى الدراسي والتخصص

\begin{tabular}{|c|c|c|c|c|c|c|}
\hline \multirow{3}{*}{ المجموع } & \multicolumn{3}{|c|}{ المستوى الدراسي } & & \multirow{2}{*}{\multicolumn{2}{|c|}{ توزيع بيانات العينـة }} \\
\hline & \multirow{2}{*}{$\begin{array}{r}\text { د دكتوراه } \\
\text { د.v } \\
r . v\end{array}$} & \multirow{2}{*}{ ماجستير } & \multirow{2}{*}{ 1. 1 . 1 . } & & & \\
\hline & & & & القيمة المتوقعة & علم نفس & \\
\hline $\begin{array}{l}01 \\
01 .\end{array}$ & $\begin{array}{r}9 \\
v . .\end{array}$ & $\begin{array}{r}r . \\
r r . r\end{array}$ & $\begin{array}{r}\text { ro } \\
r . . q\end{array}$ & القيمة المتوقعة & تربية خاصة & التضصص \\
\hline $\begin{array}{c}\text { rr } \\
\text { rr.. }\end{array}$ & $\begin{array}{r}0 \\
\varepsilon . \varepsilon\end{array}$ & $\begin{array}{l}\text { IV } \\
1 \leq .0\end{array}$ & $\begin{array}{c}1 . \\
1+.1\end{array}$ & القيمة المتوقعة & صحة نفسية & \\
\hline 11. & 10 & o. & $\leqslant 0$ & & & المجموع \\
\hline
\end{tabular}


ويبين الجدول السابق أن عدد طلاب الدراسات العليا أفراد العينة ـ 11 طالباً وطالبة، يتم توزيعهم وفقاً للتخصص TV FV تخصص علم نفس، و 10 تخصص تربية خاصة، و r r تخصص صحة

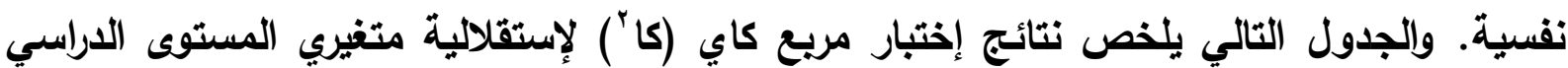
وإلتخصص.

جدول (Yr) نتائج إختبار (كاY) لإستقلالية المستوى الدراسي والتخصص (ن = • 11)

\begin{tabular}{|c|c|c|}
\hline مستوى الدلالة & درجات الحرية & القيمة \\
\hline .094 & $\varepsilon$ & r.v 9 \\
\hline
\end{tabular}

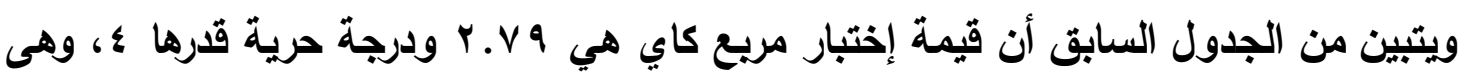

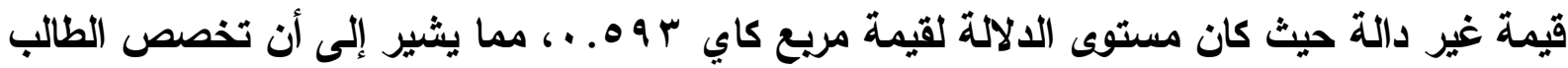
لا يعتمد على مستواه الاراسي. وللتحقق من تجانس التباين كشرط من شروط تحليل التباين، تم إستخدام إختبار ليفين Levene

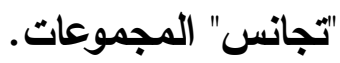
ووفقاً للنتائج السابقة تتحقق شروط إستخدام تحليل التباين، حيث تجاوزت العينة العدد · ب، وهناك إستقلالية بين المتغيرات المستقلة، وتجانس للتباين. والجدول التالي يوضح نتائج تحليل التباين

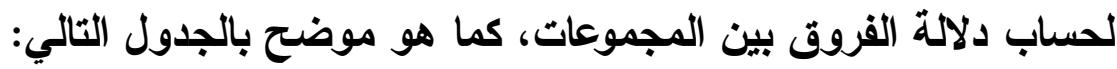
جدول (rT) تحليل التباين الثنائي للقدرة على حل المشكلات الإحصائية

\begin{tabular}{|c|c|c|c|c|}
\hline قيمة (ف) & متوسط المربعات & درجات الحرية & مجموع المريعات & المصدر \\
\hline * & $7 . .11 \mathrm{~V}$ & $\wedge$ & $\varepsilon \wedge 7.0 Y 4$ & النموذج المصحح \\
\hline *rAY.rAr & 0. К. $\leqslant \wedge 7$ & 1 & 0. К. $\leqslant \wedge q$ & بين المتغيرات \\
\hline * & . & r & rqv.1.. & المستوى الدراسي \\
\hline$\cdot . \varepsilon \cdot \Lambda$ & $0 . r \vee q$ & $r$ & 1. . vor & التخصص \\
\hline$* \varepsilon . T \leqslant Y$ & $71.1 \vee \wedge$ & $\varepsilon$ & $r \leq \varepsilon . V \backslash 1$ & التخصص \\
\hline & $1 \mathrm{M.1 \Lambda}$ & 1.1 & IrTI.IAr & الخطأ \\
\hline & & 11. & 1००v.... & التباين الكلي \\
\hline
\end{tabular}

$11 \cdot=\dot{0}$

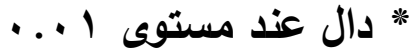

ويتضح من الجدول السابق:

1 - عدم وجود تأثير لمتغير التخصص في تباين درجات طلاب الدراسات العليا على مقياس القدرة على حل المشكلات الإحصائية. 
r - وجود تأثير دال لمتغير المستوى الدراسي على تباين درجات أفراد المجموعات الثلاثة (دبلوم خاص، والماجستير، والدكتوراه) على مقياس القدرة على حل المشكلات الإحصائية بإختلاف

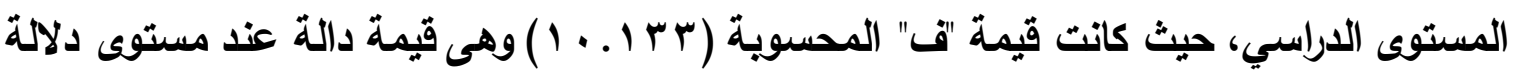
1.... وهذا يعني وجود فروق ذات دلالة بين متوسط درجات كل من طلاب الدبلوم الخاص

$$
\text { والماجستير والدكتوراه في القدرة على حل المشكلات. }
$$

ولمعرفة إتجاه الفروق بين الثلاث مجموعات من الطلاب، تم إستخدام إختبار شيفيه للمقارنات

$$
\text { البعدية، والجدول التالي يوضح نتائج المقارنات البعدية: }
$$

جدول (ع r) المقارنات البعدية بين متوسطات مجموعات طلاب الداسات العليا مختلفي المستوى

\begin{tabular}{|c|c|c|c|c|c|}
\hline \multicolumn{3}{|c|}{ الفروق بين المتوسطات } & \multirow{2}{*}{ المتوسط } & \multirow{2}{*}{ ن ن } & مجموعات \\
\hline دكتوراه & | ماجستير & ل لبلوم خاص & & & المستوى الداسسي \\
\hline *\%.107- & **\%.ฯヘ५ー & - & $0 . \Lambda \cdot v$ & @० & ل دبلوم خاص \\
\hline$\therefore \leqslant V Y-$ & - & **Y.TAY & $9.1 \vee \wedge$ & o. & ماجستير \\
\hline- & .. $\vee V T$ & $* 4.104$ & $9.1 \mathrm{Vr}$ & 10 & دكتوراه \\
\hline
\end{tabular}

(د .خاص، ماجستير، دكتوراه) في القدرة على حل المشكلات الإحصائية

$$
\begin{aligned}
& 11 \cdot=0 \\
& \text { * دال عند ه... } \\
& \text {....... }
\end{aligned}
$$

ومن الجدول السابق يتبين أن طلاب مرحلة الماجستير أكثر قدرة على حل المشكلات

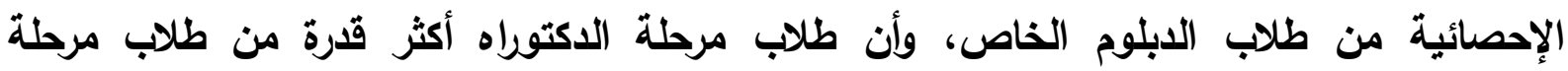

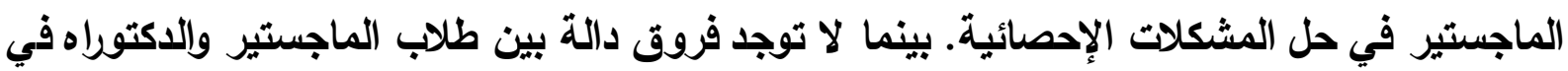

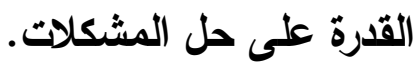
r - يوجد تأثير دال للتفاعلات الثنائية بين المستوى الدراسي والتخصص على تباين درجات أفراد

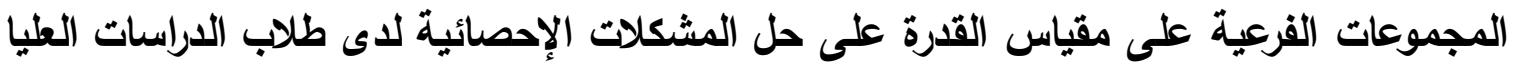

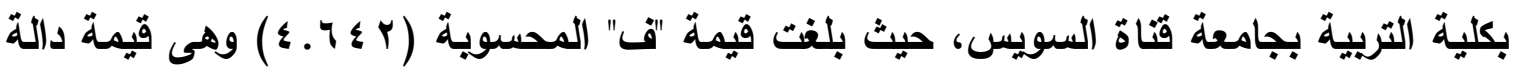

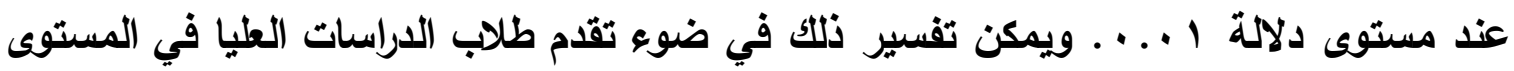

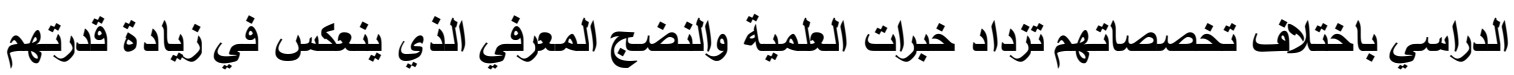
على حل المشكلات الإحصائية، وأظهر طلاب مرحلة الاكتوراه ذوي أعلى مستوى دراسي النفي بين أفراد

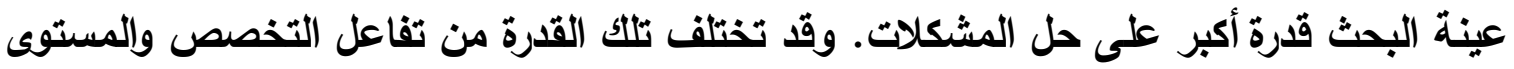

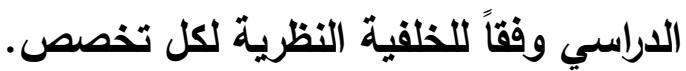




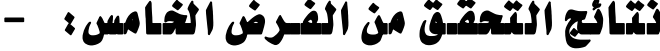

ينص الفرض الخامس على "توجد تأثيرات سبيبة بين القدرة على حل المشكلات الإحصائية كمتغير تابع، ووجهة الضبط، وأبعاد التنافر المعرفي (البعد الثخصي، والبعد الإجتماعي) كمتغيرات مستقلة، من خلال أبعاد فاعلية الذات البحثية (المبادأة والمثابرة، وتحمل المسئولية البحثية، والثقة بالنفس) كمتغير وسيط". وللتحقق من النموذج النظري المقترح للفرض الخامس الذي يفسر العلاقات بين متغيرات البحث تم إجراء الاسلوب الإحصائي تحليل المسار Path Anaysis للنموذج المفترض، وذلك بإستخدام برنامج الليزرال (Lisrel 8.8). وهدفت الباحثة من تحليل المسار إلى التعرف على العلاقات السبيية من خلال معاملات الإرتباط بين المتغيرات المستقلة كما تتمثل في متغير وجهة الضبط، وأبعاد متغير التنافر المعرفي

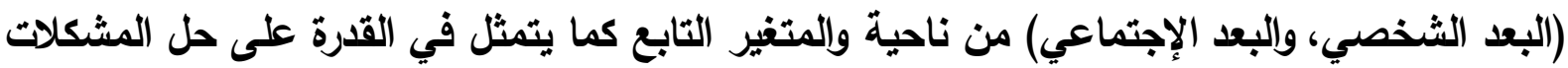

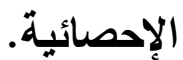

كما إعتبرت أبعاد متغير فاعلية الذات البحثية (المبادأة والمثابرة، وتحمل المسئولية البحثية، والثقة بالنفس) متغيرات مستقلة والقدرة على حل المشكلات الإحصائية متغير تابع لها، ويعتمد تحليل

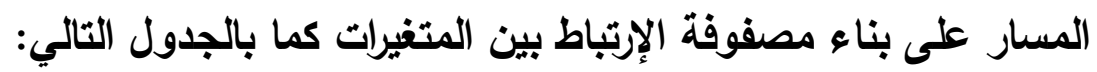

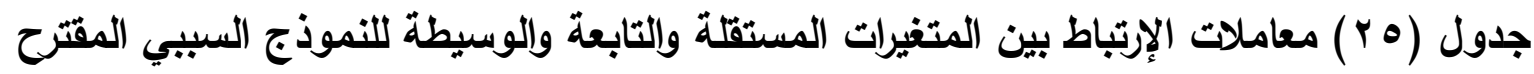

\begin{tabular}{|c|c|c|c|c|c|c|c|}
\hline الضبط & الثقة بالنفس & تلمسئلية & والمثادرة & الإجتماعي المعرفي & الثخصي التعرفي & المشكلات على حل & الأبعاد \\
\hline & & & & & & $1 \ldots$ & القشكلات \\
\hline & & & & & $1 \ldots .$. & **..rYY- & التخافري المعرفي \\
\hline & & & & $1 \ldots$ & $* * . . v \leq q$ & *..rYo- & التتافر $\quad$ المعرفي \\
\hline & & & $1 \ldots$ & ***.「リ & "..YYY- & $* * \ldots \leq 04$ & المبادأة والمثابرة \\
\hline & & $1 \ldots$ & $* * \ldots$ * $\mathrm{VV}$ & ***. . & *..rTI- & $* * . .0 . r$ & تحمل $\quad$ لمسئولية \\
\hline & $1 \ldots$ & $* * . .7 \leqslant 9$ & $* * . .0 \leqslant$ & $* . . r \leqslant 9-$ & *..TVV- & $* * . .490$ & الثقة بالنفس \\
\hline$\ldots$ & ***.rVo- & ***..६।V- & ***..กด४ & $* . .1 r \mu$ & $* . .119$ & $* *$ *. & وجهة الضبط \\
\hline
\end{tabular}

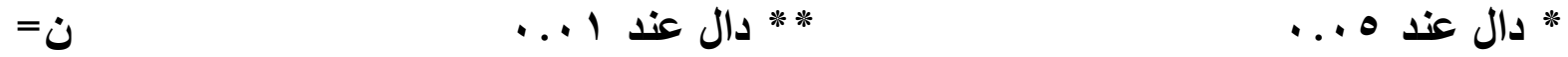


ويتضح من نتائج الجدول السابق أن جميع معاملات الإرتباط بين المتغيرات دالة. وتم حساب

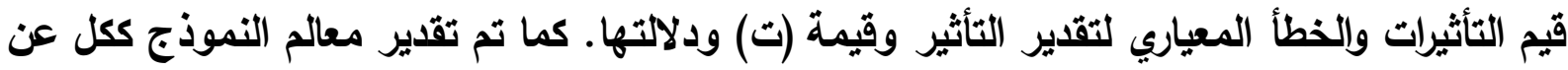
طريق مؤشرات حسن المطابقة. وفيما يلي جدول يوضح قيم التأثيرات.

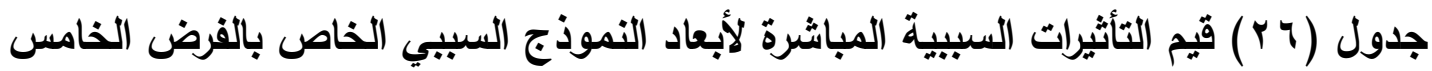

\begin{tabular}{|c|c|c|c|c|c|}
\hline $\begin{array}{r}\text { معامل } \quad \text { الثبات } \quad\left(R^{2}\right)\end{array}$ & قيمة "ت" ودلالتها & الخطأ المعياري & التأثير & المســـار & b \\
\hline . & *Y. ¿ Y५ & $\cdots \wedge \wedge$ &.$Y 17$ & المثكلات المبادة والمثابرةّـ القرة على حل & 1 \\
\hline . & $* * r . r .1$ & $\cdots 9$ & $\because r \wedge q$ & 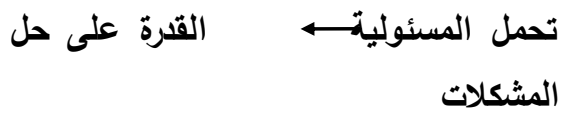 & r \\
\hline 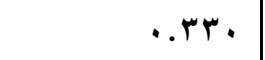 & 1.111 & $\cdots \wedge 9$ & $\cdots 99$ & الثقة بالنفس ـــالقدرة على حل المشكلات & $r$ \\
\hline . & $* *$ *.^^.- &.$|r|$ & . r. & التشكلافر الثخصيـــ القرة على حل & $\varepsilon$ \\
\hline 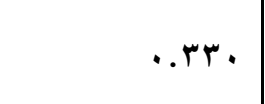 & $. .100-$ &. $.1 \mu r$ & $\because r \cdot \theta$ & 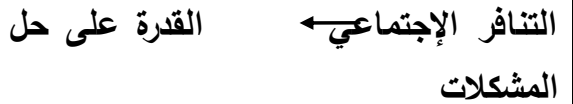 & ○ \\
\hline . & $. .949-$ & $\because .97$ & $\cdots \wedge \wedge_{-}$ & وجهة الضبط ــــالقدرة على حل المشكلات & 7 \\
\hline . rM. & $\cdot . \varepsilon \cdot V$ & $.1 r q$ & $\ldots$ or & التنافر الثخصي ـــــالمبادأة والمثابرة & $v$ \\
\hline .rr. & $*$ *.rq $\varepsilon-$ & $.1 r q$ & $\cdot r \cdot \Lambda-$ & التنافر الإجتماعي ـــ المبادأة وإلمثابرة & $\wedge$ \\
\hline . RT. & $* * \varepsilon . Y 01-$ & $\cdots \wedge \uparrow$ & $. .470-$ & 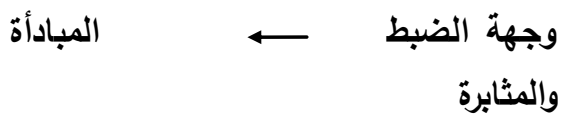 & 9 \\
\hline .rVY & $\cdot . \wedge 1 \leq$ & .1 ro & $\cdot 1 \cdot r$ & التنافر الثخصي ــــــــ المسئولية & 1. \\
\hline. YVT & $* *$ T.I r $\varepsilon-$ & .1 ro & $. . r q \cdot-$ & 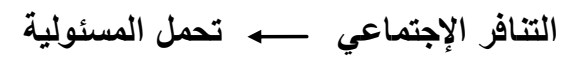 & 11 \\
\hline . YVY & $* \% \varepsilon . \Delta V Y-$ & $\cdot . \wedge r$ &.. $\mathrm{r \Lambda I-}$ & 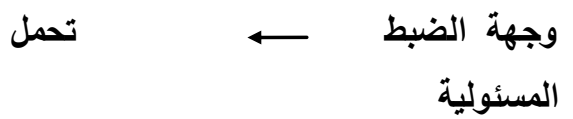 & ir \\
\hline$\cdot r \leq V$ & $* * \ldots . .1 \leq$ &. $.1 \mathrm{rV}$ & $\cdot r \wedge \varepsilon$ & التنافر الشخصي ــ الثقة بالنفس & ir \\
\hline$. r \leq V$ & **ั.ง ะ &. $.1 Y V$ & $\cdot . \leqslant q \curlyvee-$ & التنافر الإجتماعي ــــالثقة بالنفس & $1 \varepsilon$ \\
\hline$. r \leq V$ & $* * \varepsilon . r r V-$ & $\cdots \wedge 0$ & $. .47 .-$ & وجهة الضبط & 10 \\
\hline
\end{tabular}

وقد أسفرت النتائج الموضحة بالجدول السابق عن:

ا - يوجد تأثير سببي دال عند مستوى ه ... لبعد المبادأة وإلمثابرة (من أبعاد فاعلية الذات البحثية)

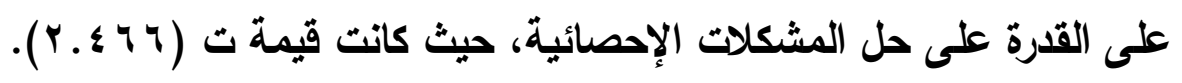

r - يوجد تأثير سببي دال عند مستوى ا I. .. لبعد تحمل المسئولية البحثية (من أبعاد فاعلية الذات

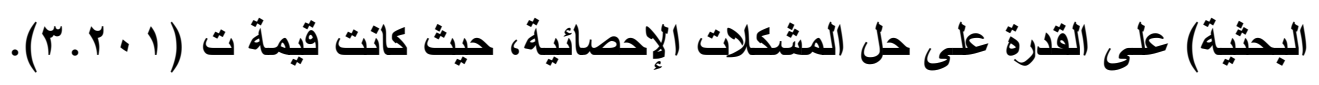


ب - لا يوجد تأثير سببي دال لبعد الثقة بالنفس (من أبعاد فاعلية الأات البحثية) على القدرة على حل

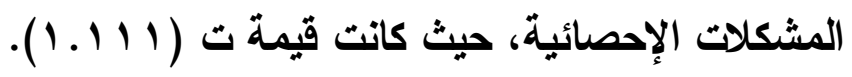

ـ - يوجد تأثير سببي سالب دال عند مستوى 1 ... للبعد الشخصي (من أبعاد التنافر المعرفي) على

$$
\text { القدرة على حل المشكلات الإحصائية، حيث كانت قيمة ت (- . ^^. ب). }
$$

ه - لا يوجد تأثير سببي دال للبعد الإجتماعي (من أبعاد التنافر المعرفي) على القدرة على حل

$$
\text { المشكلات الإحصائية، حيث كاتت قيمة ت ( -ه ه } 1 \text {. .). }
$$

צ - لا يوجد تأثير سببي دال لوجهة الضبط على القدرة على حل المشكلات الإحصائية، حيث كانت

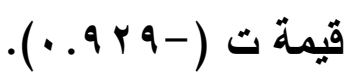

V - لا يوجد تأثير سببي دال للبعد الشخصي (من أبعاد التنافر المعرفي) على بعد المبادأة والمثابرة

$$
\text { (من أبعاد فاعلية الذات البحثية)، حيث كانت قيمة ت (v ع ـ • ). }
$$

1 - يوجد تأثير سببي سالب دال عند ه .. . للبعد الإجتماعي (من أبعاد التنافر المعرفي) على بعد

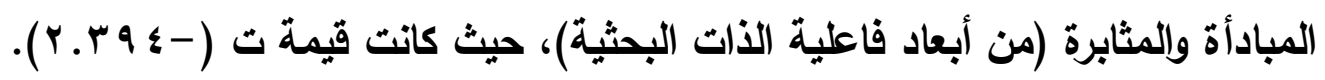

9 - يوجد تأثير سببي سالب دال عند ا +. . لوجهة الضبط على بعد المبادأة والمثابرة (من أبعاد

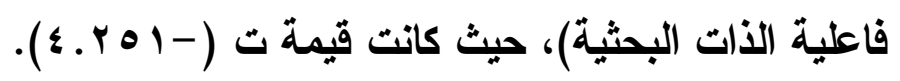

• 1 - لا يوجد تأثير سببي دال للبعد الشخصي (من أبعاد التنافر المعرفي) على بعد تحمل المسئولية

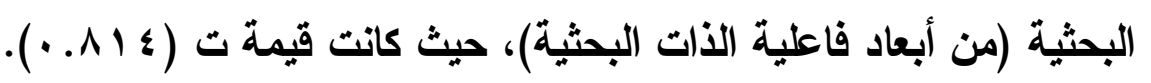

1 - 1 يوجد تأثير سبيب سالب دال عند 1 ... للبعد الإجتماعي (من أبعاد التنافر المعرفي) على بعد

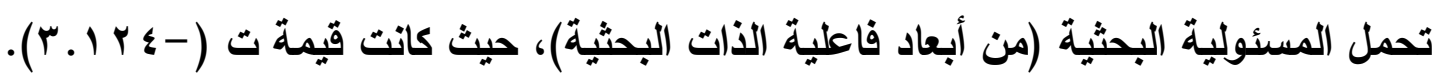

ץ ا - يوجد تأثير سبي سالب دال عند I . . . لوجهة الضبط على بعد تحمل المسئولية البحثية (من

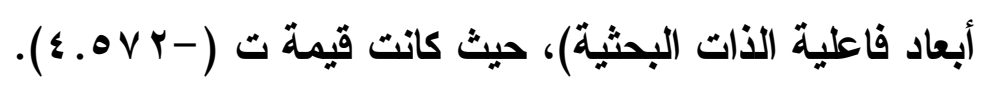

ب ا - يوجد تأثير سببي دال عند 1 ... للبعد الشخصي (من أبعاد التنافر المعرفي) على بعد الثقة

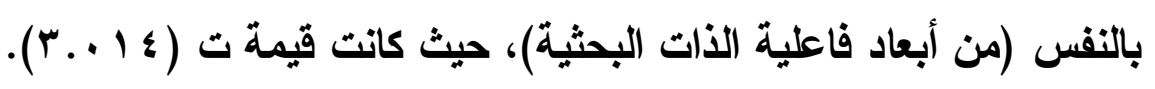

ع ا - يوجد تأثير سببي سالب دال عند ا ... للبعد الإجتماعي (من أبعاد التنافر المعرفي) على بعد

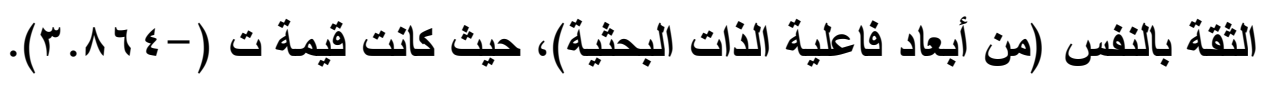

ه - يوجد تأثير سببي سالب دال عند ا ب. . . لوجهة الضبط على بعد الثقة بالنفس (من أبعاد فاعلية

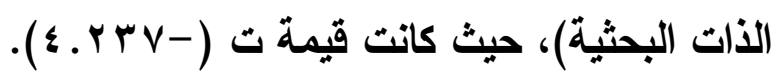


وفيما يلي النموذج السببي المعدل بتأثيراته:

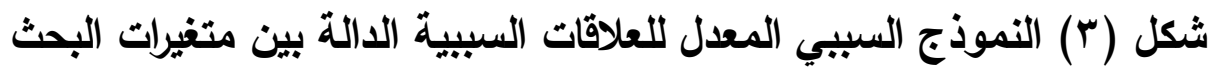

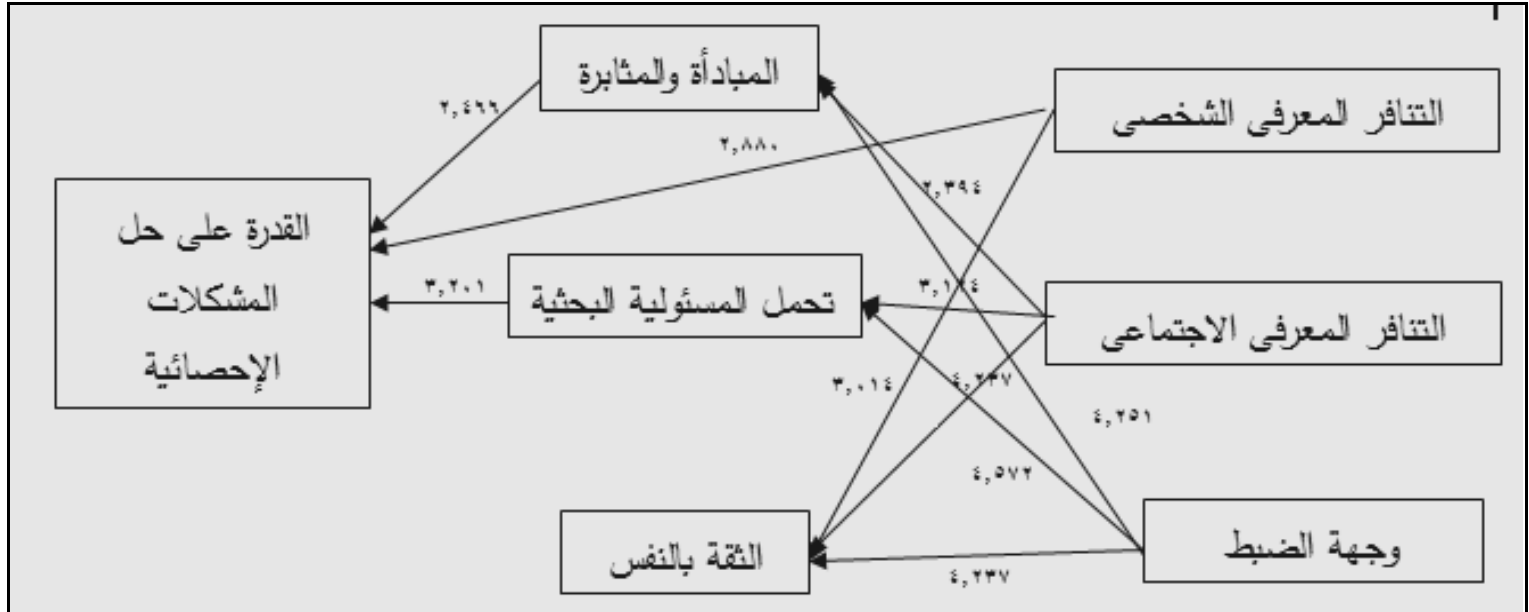

وقد إختبرت صحة النموذج بإستخدام كا` (x²) لحسن المطابقة، ويلغت قيمتها ؛ ...

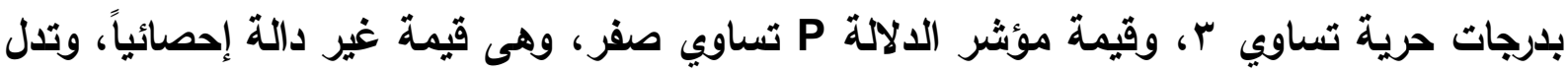

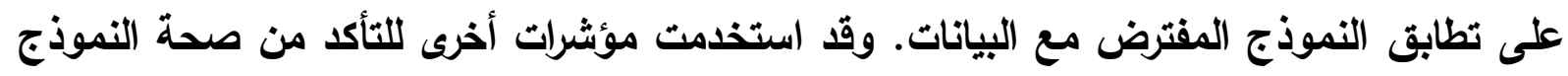
وفيما يلي عرضاً لمؤشرات حسن المطابقة للنموذج السبيبي:

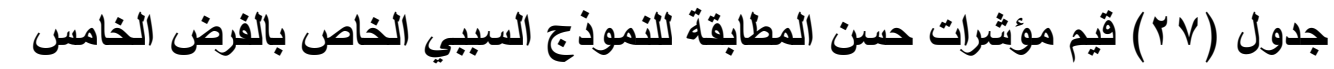

\begin{tabular}{|c|c|c|c|c|c|c|c|c|c|}
\hline$x^{x^{2}}$ & AGFI & GFI & IFI & CFI & NNFI & NFI & RMR & RMSEA & المؤشر \\
\hline \& & ו & . .104 & . . &.$V R \wedge$ & $\begin{array}{c}- \\
.0011\end{array}$ & $\therefore \vee \wedge \wedge$ &. $.11 \mathrm{~V}$ & ג & القيم \\
\hline
\end{tabular}

ومن نتائج الجدول السابق يتضح اتفاق مؤشرات حسن المطابقة للنموذج المقترح مع البيانات،

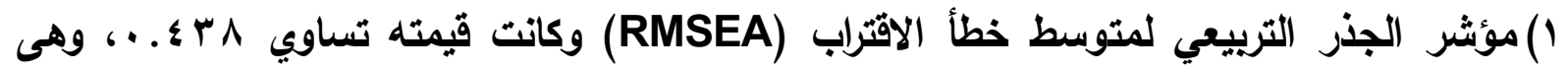
تنحصر بين (صفر، ())، والقيم المنخفضة التي تقترب من الصفر تدل على أن النموذج المقترح يتطابق جيداً مع البيانات

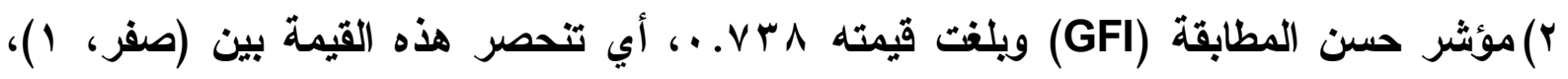

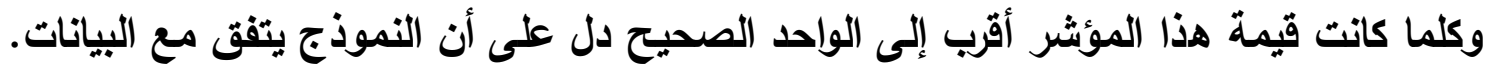

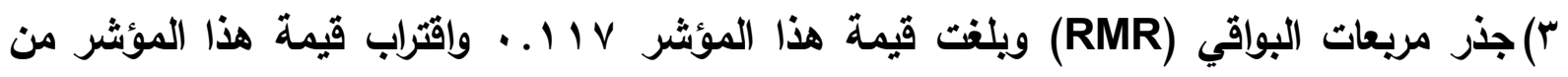
الصفر تلال على أن النموذج يتفق مع البيانات.

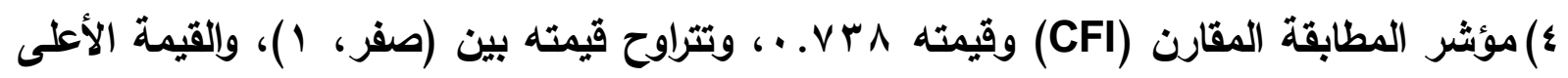
تثير إلى تطابق أفضل والمطابقة الجيدة تساوي وإحد صحيح. 


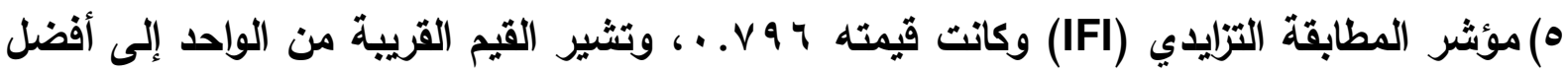
مطابقة، بينما تثير القيم القريبة من الصفر إلى أسوء مطابقة.

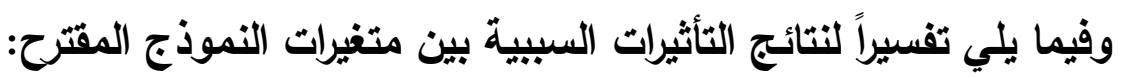
1-وجود تأثير سببي دال إحصائياً عند مستوى دلالة ه ... . لبعد المبادأة والمثابرة (من أبعاد فاعلية

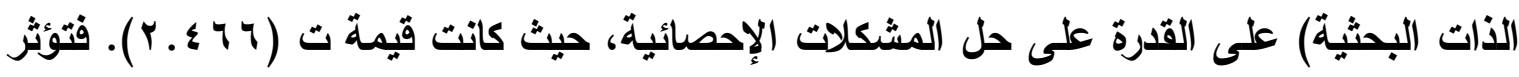

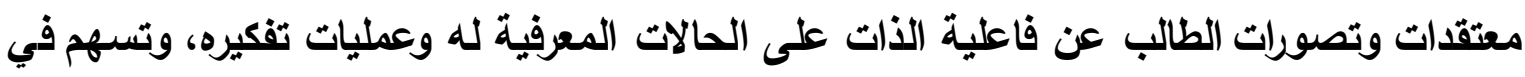
تفسير سلوكه عند أداء المهام البحثية المختلفة، فكلما زادت فاعلية الذات البحثية وتصورات الطالب عن قدرته على تحمل المسئولية كلما بذل مزيداً من الجهد والمثابرة لمواجهة المشكلات الماته

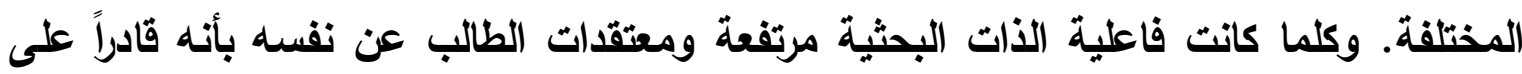

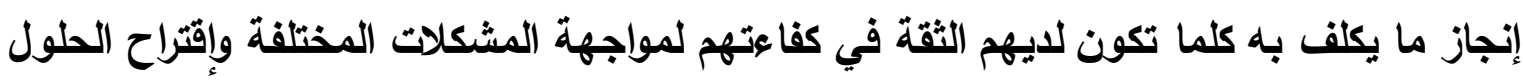

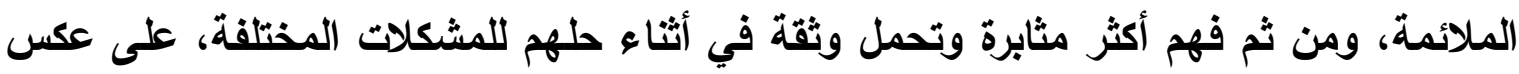

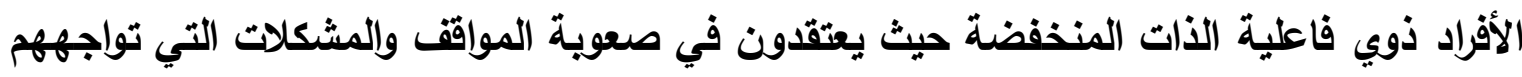
أكثر من واقع صعويتها. r - وجود تأثير سبيب دال إحصائياً عند مستوى دلالة ا ل... لبعد تحمل المسئولية البحثية (من أبعاد

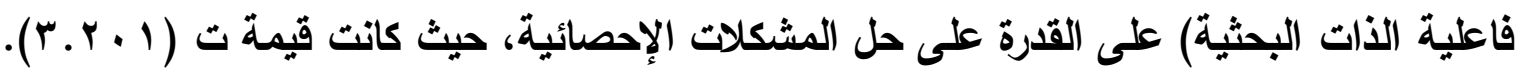

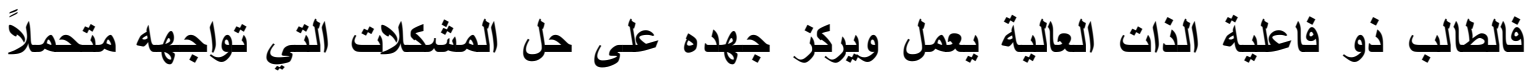
مسئولية ذلك، في حين أن الطالب ذو الفاعلية الذاتية الأقل يميلون إلى تجنب هذه هل التهل المهام.

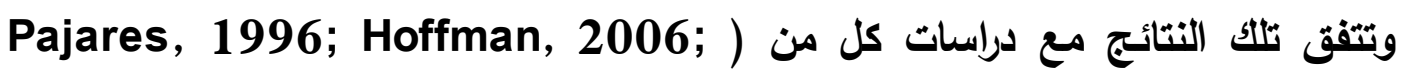
(Butler, 2008; Zheng, McAlack, Wilmes, Evans, \& Williamson, 2009 التي أوضحت أن الأفراد ذوي فاعلية الذات المنففضة يميلون إلى إدراك الموقف على أنه يمثل

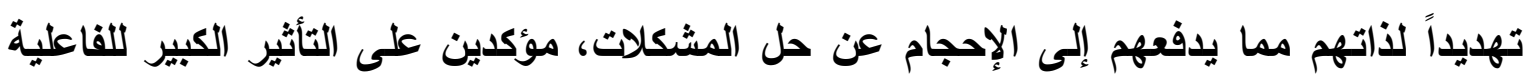
الأتية على الأداء والكفاءة في حل المشكلات. ץ - وجود تأثير سببي سالب دال إحصائياً عند مستوى دلالة الاءل ... للبعد الثخصي (من أبعاد التنافر

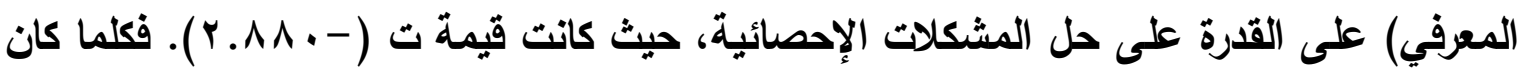
الطالب يعاني من تنافراً معرفياً كانت قدرته على حلى حل المشكلات أقل، فحينما ينفذ تعليمات مشرفهاته دون إقتناعه بها يؤثر في عمليات تفكيره في مواجهة وحل المشكلات، والطالب الذي يسجل فئل

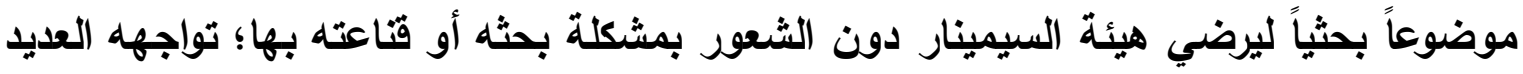

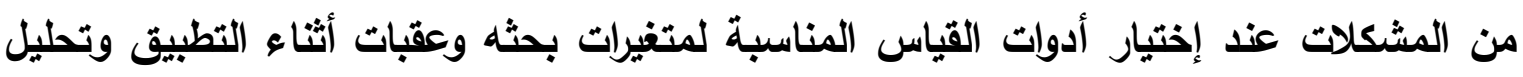
البيانات ولا يستطيع مواجهة وحل تلك المشكلات. 
Wisniarti \& Sugiman, ) وتتقق هذه النتيجة مع دراسة ويسنيارتي وسوجيمان

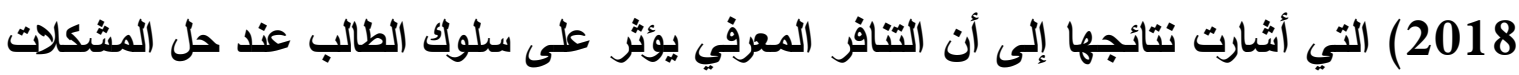
الرياضية، ويؤثر سلبياً في قدرته على إتخاذ القرار المناسبة وتبيني الإستراتيجيات الفعالة أثثاء حل المشكلات.

ع - وجود تأثير سبي سالب دال إحصائياً عند مستوى دلالة ال...

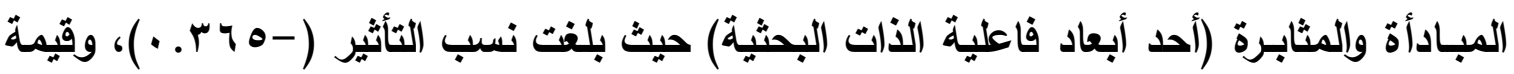

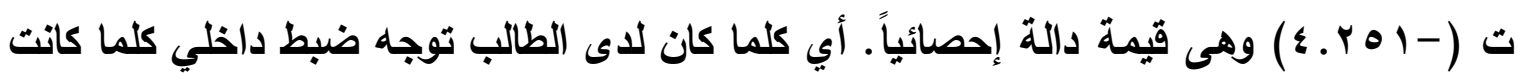

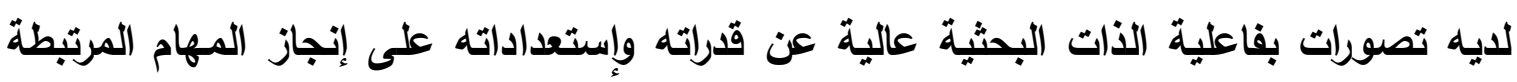
بالبحث العلمي، وكلما تبنى الفرد وجهة ضبط داخلين كان أكثر قدرة على تحديد أهدافه مسبقاً،

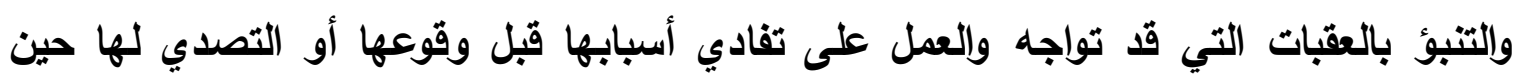

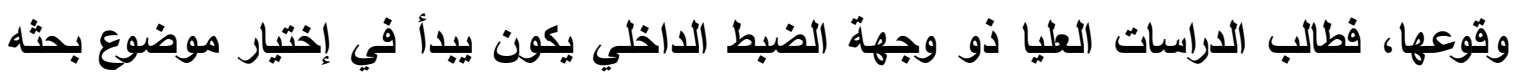
والبحث في شبكة الإنترنت عن المراجع والدراسات السابقة المرتبطة دون انتظار توجيه المشرفين

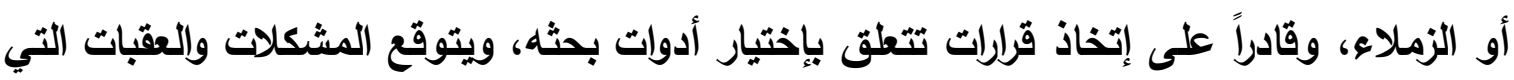
قد تواجهه عند تطبيق أدوات البحث والعمل على مواجهتها، كما أنه يضع تصوراً مسبقاً للأسئلة

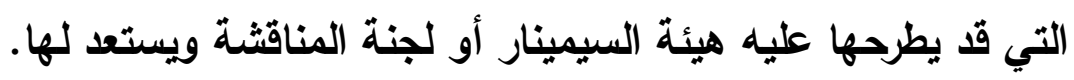

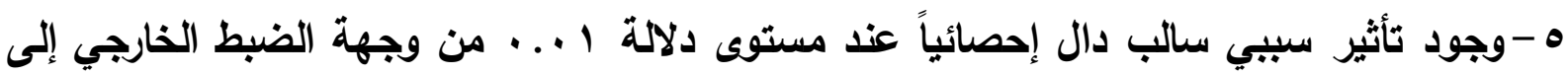

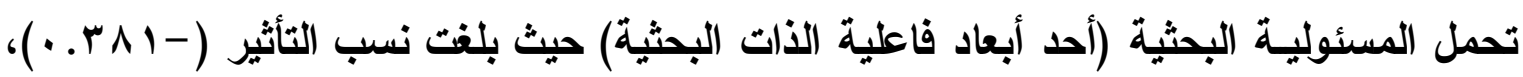

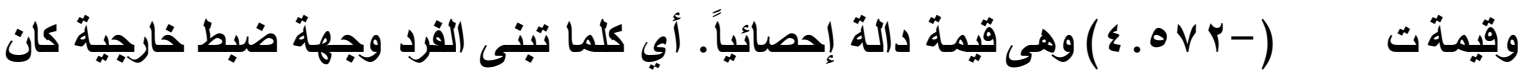

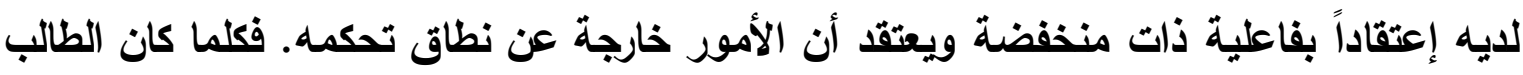

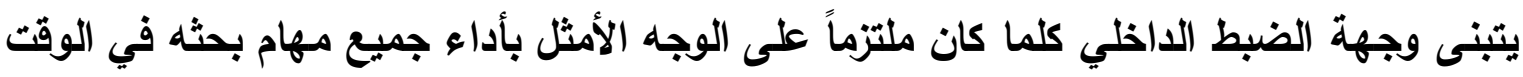

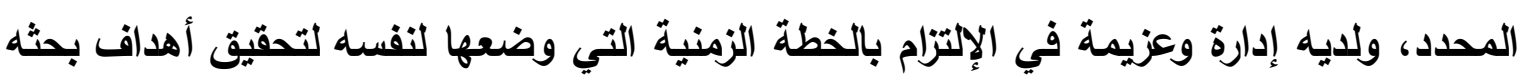

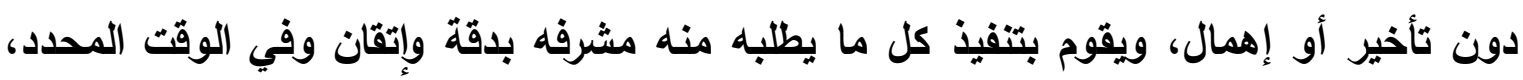

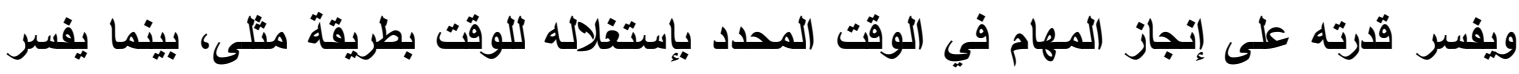

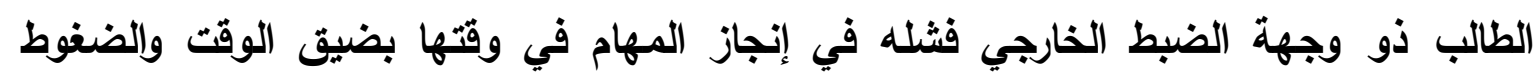
المحيطة به أو لعدم مراعاة المشرف لظروفه الأسرية أو المهنية.

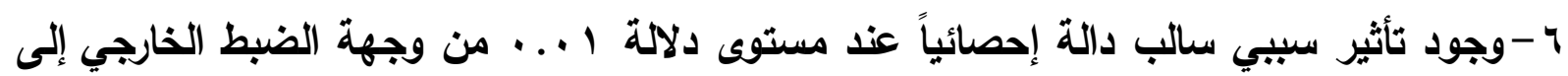

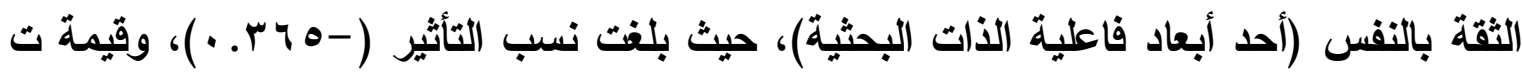

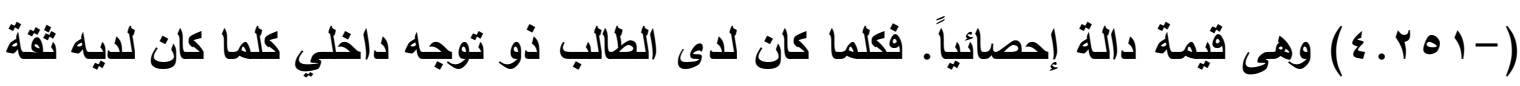


في قراته وإمكانياته البحثية وقادراً على توظيف تلك الإمكانيات والقدرات في مجال البحث العلمي، ويفسر نجاحه أو فشله في إنجاز مهام البحث العلمي في ضوء هذه القدرات.

وتثتق تلك النتائج السابقة مع دراسة كاريفيو وروديس (Carifio \& Rhodes, 2002 (r)

ودراسة نايف بن محمد الحربي، ونفين بنت محمد زهران (9 . . r)، ودراسة عفاف سالم المحمدي ( ا التي اتفقت على تبني الأفراد ذوي فاعلية الذات العالية وجهة ضبط داخلية، بينما يتبنى الأفراد ذوي فاعلية الأت المنخفضة وجهة ضبط خارجية. V- Vودو تأثير سببي دال عند I ... للبعد الشخصي (من أبعاد التتافر المعرفي) على بعد الثقة بالنفس (من أبعاد فاعلية الذات البحثية)، حيث كانت قيمة ت (ع ا . . ب). ويفسر ذلك بأن الفرد الأي يعاني من حالة صراع داخلي بين ما يتبناه من أفكار وإتجاهات وما يقوم به هو نفسه سعياً

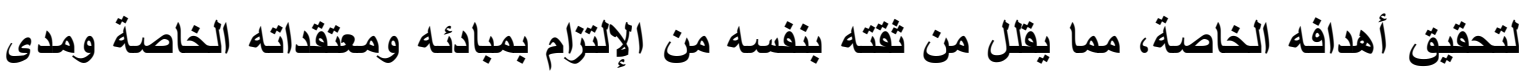
قدرته على توظيفها في الوصول لأهدافه. 1 -وجود تأثير سببي سالب دال عند ا ... للبعد الإجتماعي (من أبعاد التتافر المعرفي) على بعد (المبادأة والمثابرة (أحد أبعاد فاعلية الأات البحثية)، حيث كاتت قيمة ت ( - צ 1 .ب). حيث أن الطالب الأي يعاني من صراعاً معرفياً وحالة من الضيق وعدم الإرتياح يضطر لتغيير آراؤه وإتجاهاته وأفكاره ليساير سلوك الجماعة أو تعاطقاً مع الآخرين، مما يؤخره عن إنجاز أهدافه فقد يضطر إلى تأخير تسليم تكليفاته التي إنتهى من إنجازها لحين أن ينتهي زميله من الإستفادة منها. 9-وجود تأثير سببي سالب دال عند ا ... للبعد الإجتماعي (من أبعاد التنافر المعرفي) على بعد

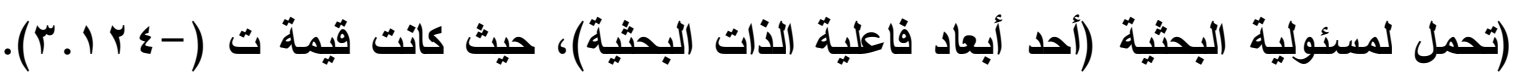
فكلما زاد التخافر المعرفي الإجتماعي تقل المسئولية البحثية لاى الطلاب الباحثين؛ فالطالب الذي يعاني صراعاً معرفياً بين أفكاره وإتجاهاته وما يقوم به من أجل الحفاظ على إنتماؤه للجماعة؛ قد يبرل لتفسه التأخر في إنجاز الجزء المكلف به من البحث الجماعي في ضوء أن الجميع لم يُسلم ما هم مكلقين به، وفي ذلك عدم تحمل المسئولية على إنجاز مهامه المكلف بها في وقتها، كما أنه لا يلتزم بالخطة الزمنية التي أعدها لنفسه مما يشعره بتناقض بين قدراته وما يقوم به، ويعتمد على ما يقوم به زملاؤه بتجميعه من مراجع ودراسات سابقة دون التحري عن مصداقيتها، وإذا إكتشف تزييفاً للبيانات أو لتوثيق المراجع البحثية من أحد زملاؤه لا يعترض ولا يحاول التعديل بالرغم من أن ذللك يخالف ما يعتقده وما يؤمن به من الدقة في توثيق المعلومات والبيانات، مما يشير لعدم مسئولية بحثية وشعوراً بعد الرضا والإرتياح. • - وجود تأثثر سببي سالب دال عند ه . . . للبعد الإجتماعي (من أبعاد التنافز المعرفي) على بعد

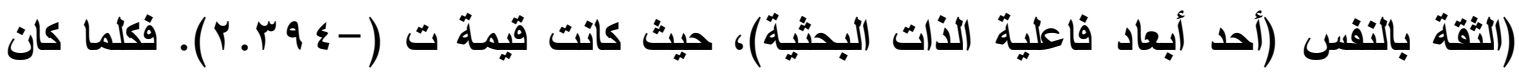


الطالب يعاني تنافراً معرفياً بما يؤمن به وأفكاره وإتجاهاته ويين ما يسلكه من تصرفات ليساير أفراد جماعته من الأقران، كلما كان أقل ثقةً بنفسه وقدراته على مواجهة التحديات، وإنجاز المهام البحثية في وقتها وعلى أكمل وجه، ففي الوقت الذي يرفض فيه الغش والتزييف يبرر لزميله ما يفعله نظراً لمروره بظروف طارئة مما يفقده الثقة في أحكامه وقيمه التي يؤمن بها.

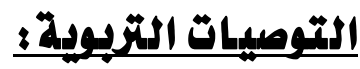

ا ـ إجراء مزيد من الدراسات تهدف لتحسين فاعلية الذات لايهم، مما يساعدهم على إتخاذ قراراتهم بإستقلالية ووفقاً لقدراتهم وخصائصهم.

r. العمل على إعداد وتتفيذ التدوات العلمية والبرامج التدريبية التي تساهم في تعزيز وجهة الضبط الاخلي وفاعلية الأت لاى الطلاب الباحثين. ب. بناء برامج تلريبية لخفض التنافر المعرفي لاى طلاب الدراسات العليا، وقياس أثرها على أداء المهام المعرفية، وخاصة القدرة على حل المشكلات. ع. تصميم برامج تدريبية للطلاب الباحثين على مهارة حل المشكلات وكيفية إستخدامها وتطبيقاتها العملية في إنجاز البحوث العلمية. 


\section{المراجع الأجنبية والعربية.}

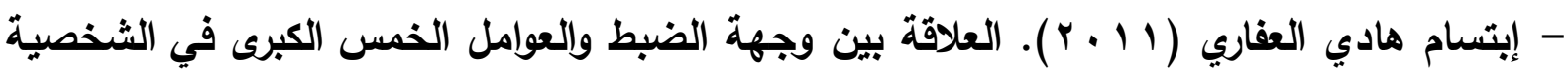

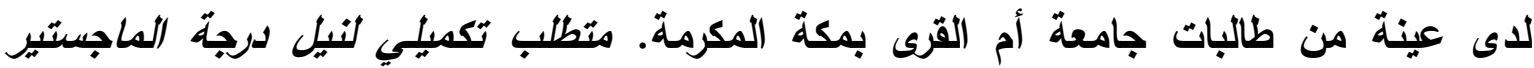

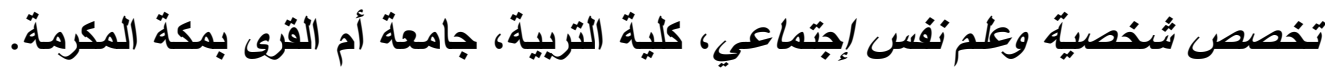

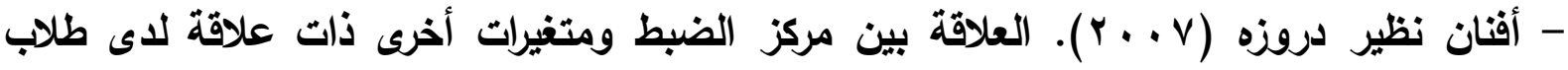

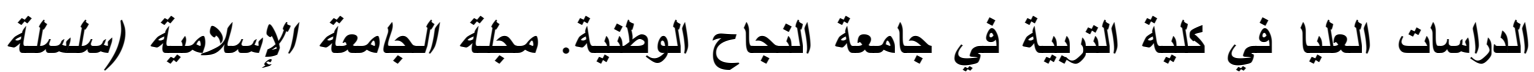

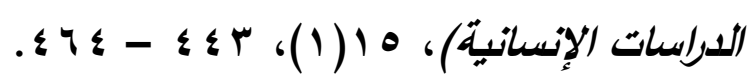

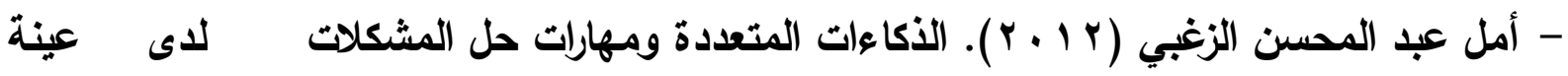

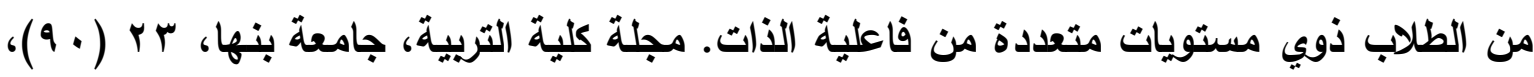

$$
\text { .r\A-r... }
$$

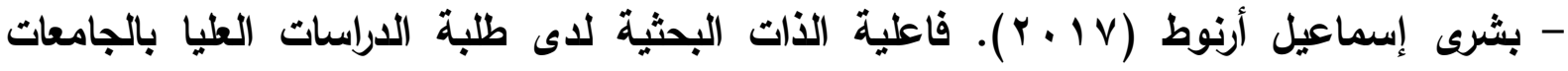

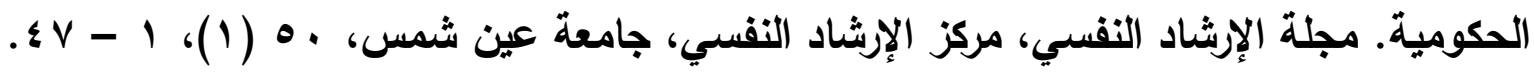

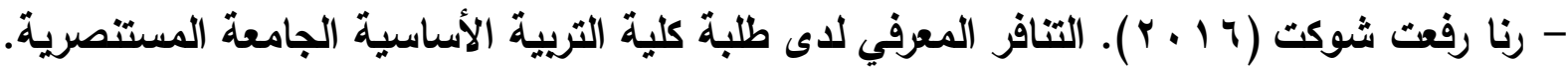

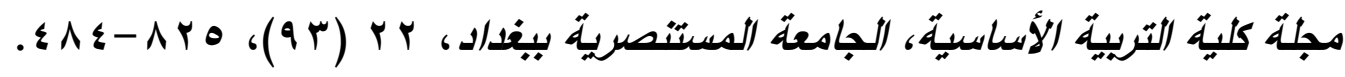

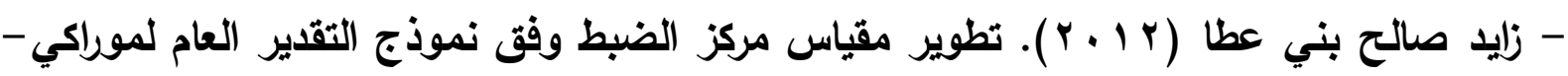

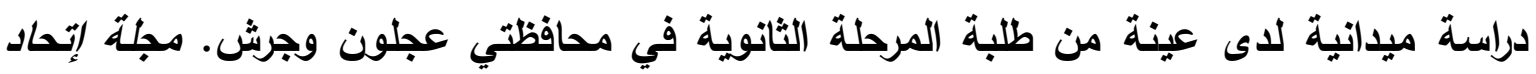

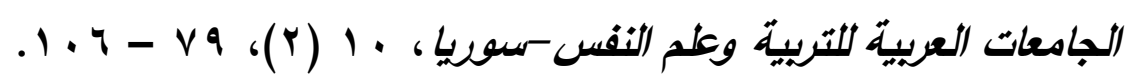

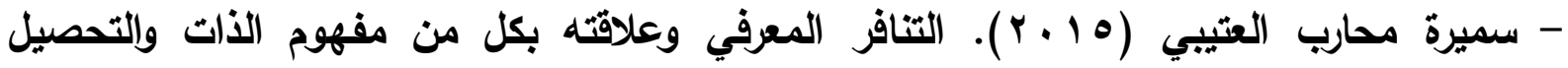

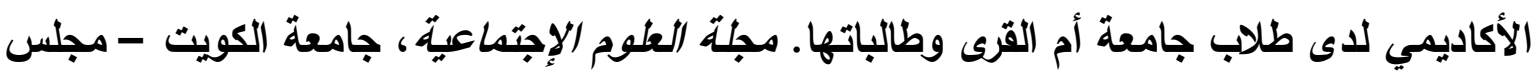

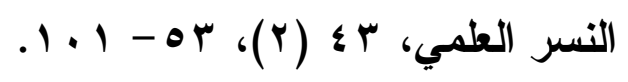

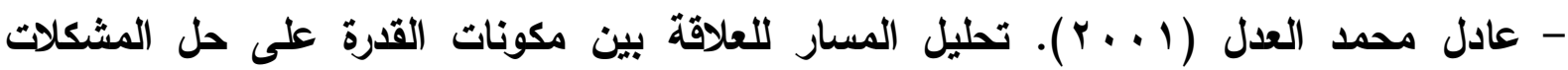

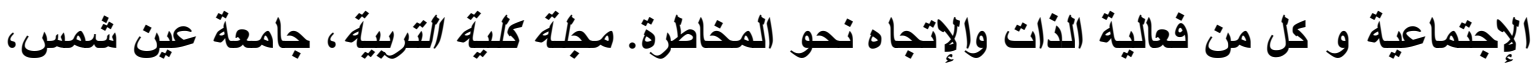

$$
\text { O }
$$

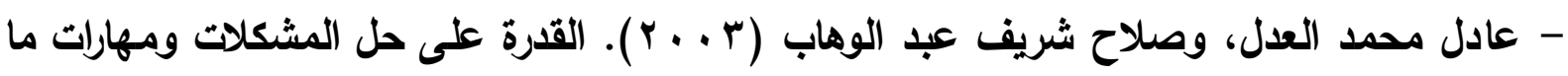

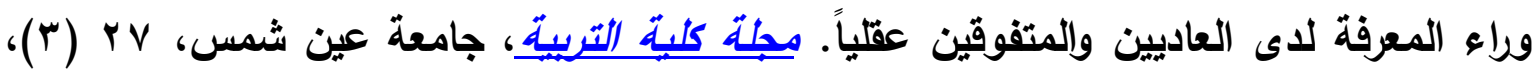

$$
. \nvdash \bullet \wedge-\mid \wedge 1
$$

- عايش موسى غرايبة، وابراهيم عبد الله الزريقات (10 ب ب). مركز الضبط لاى الطلبة الجامعيين

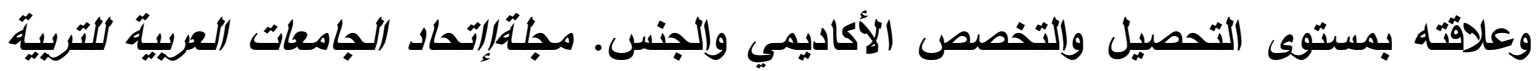

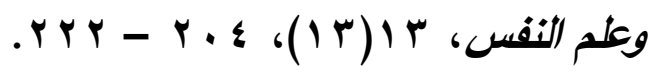




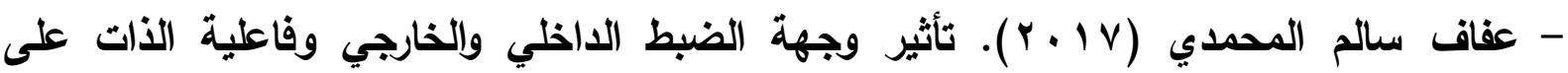

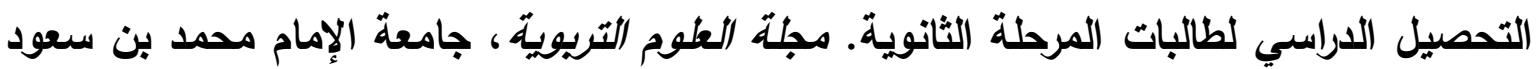

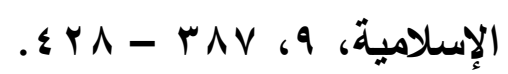

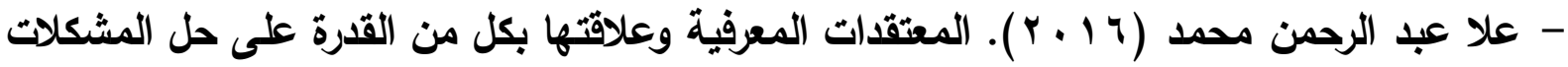
وقلق الإختبار والتحصيل الأكاديمي لاى الطالبات المطلمات برياض الأطفال بالجامعة. مجلة المعلة

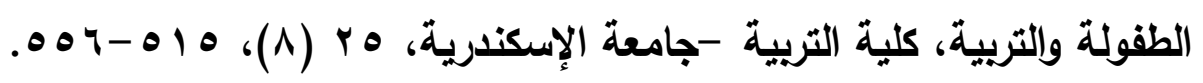

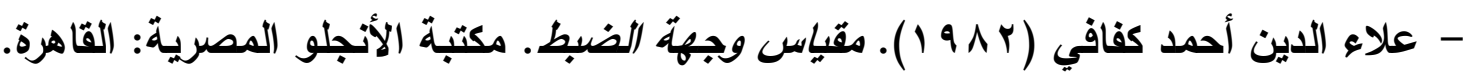

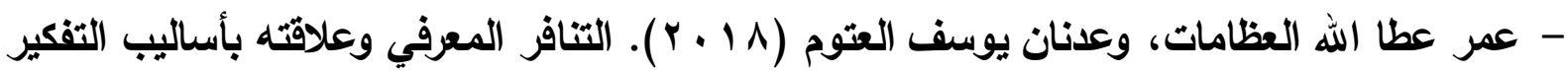
ومصادر الاعم الإجتماعي لدى طلبة جامعة اليرموك. مجلة جامعة القلس المفتوحة للأبحاث

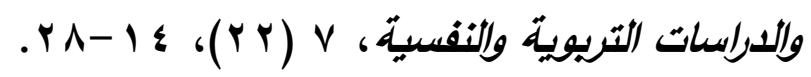

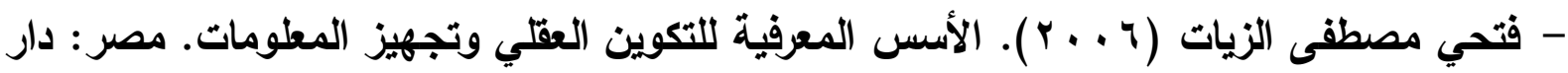
النشر للجامعات، طץ.

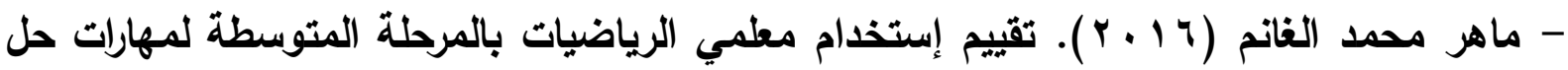

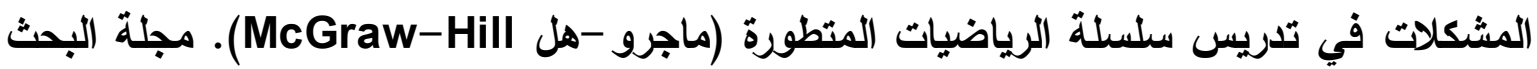

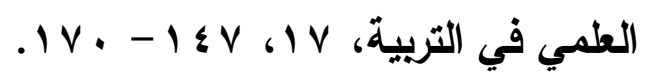

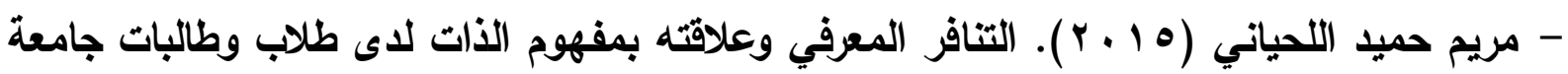

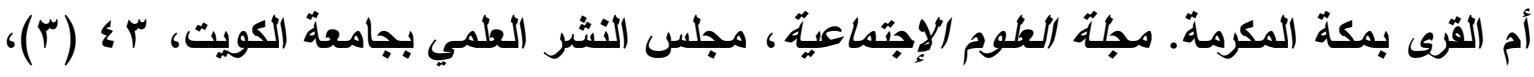

$$
.97 \text { - } 0 .
$$

- مريم حميد اللحياني، وسميرة محارب العتيبي (10 ب ب). بناء مقياس للتنافر المعرفي وتقدير خصائصه السيكومترية لطالبات جامعة أم القرى بمكة المكرمة. مجلة الدراسات التربوية والنفسية،

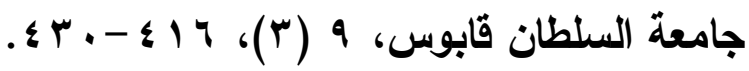

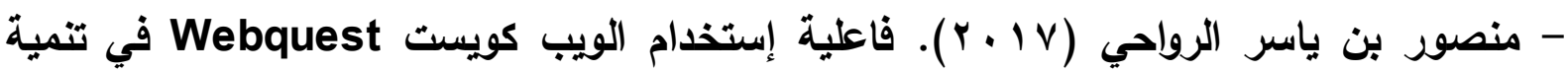
مهارات حل المشكلات الإحصائية وفاعلية الذات لاى طلبة الصف العاشر الأساسي بسلطنة عمان. مجلة بحوث الملتقى، الصادة عن كلية التريبية-جامعة بنها، الملتقى الدولي الأول: تطبيقات الماته

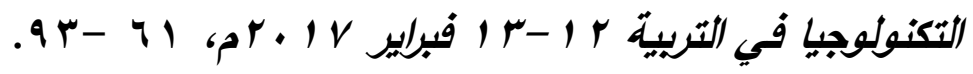

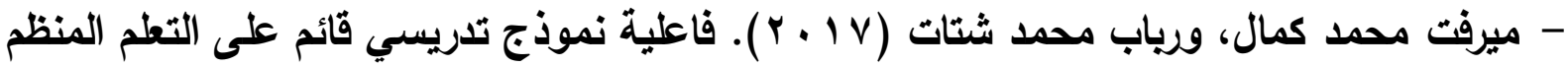

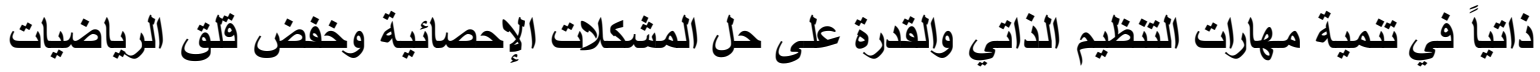

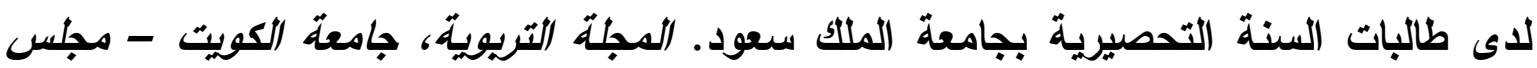

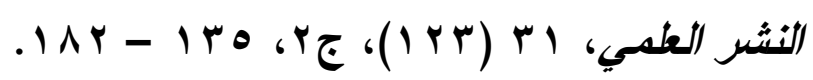




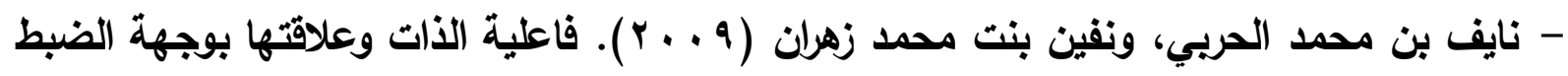

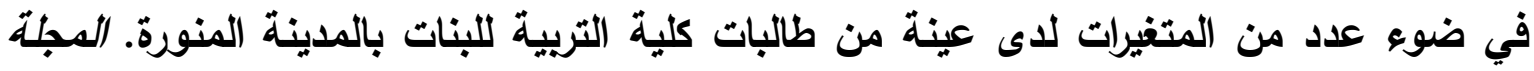

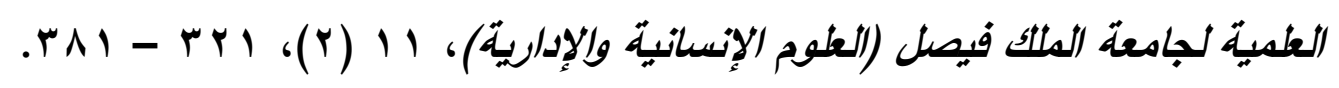

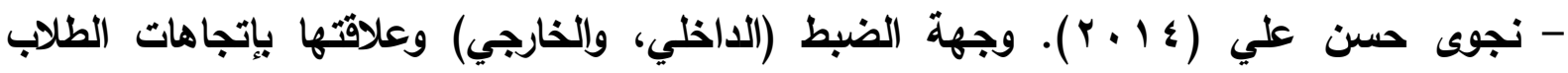

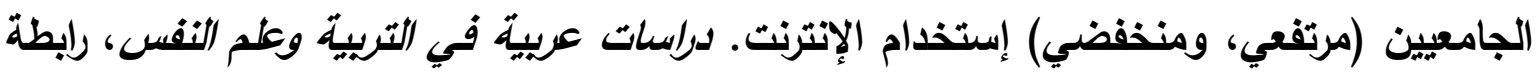

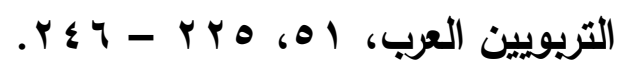

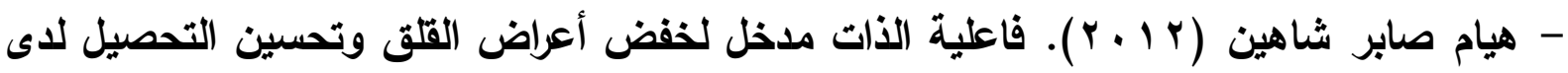

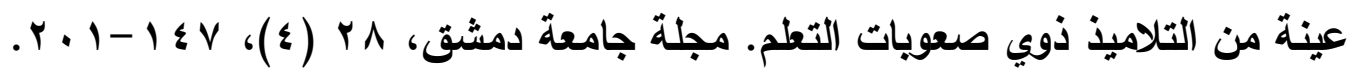

- Antoniou, C., Doukas, J. A., \& Subrahmanyam, A. (2013). Cognitive Dissonance, Sentiment, and Momentum. Journal of Financial and Quantitative Analysis, 48(1), 245-275.

- Balcetis, D. \& Dunning, E. (2007). Cognitive Dissonance and The Perception of Natural Environments. Psychological Science, 18(10), 917921.

- Bandura, A. (1994). Self-Efficacy. In V. S. Ramachaudran (Ed.), Encyclopedia of Human Behavior, Vol. 4, (pp. 71-81). New York: Academic Press.

- Bandura, A. (2006). Guide for Constructing Self-Efficacy Scales. In F. Pajares, T. C. Urdan (Eds.), Self-Efficacy Beliefs of Adolescent (pp. 307337). Information Age Publishing.

- Bandura, A. (2009). Cultivate Self-Efficacy for Personal and Organizational Effectiveness. In E. A. Locke (Ed.), Handbook of Principles of Organizational Behavior, $2^{\text {nd }}$ Ed., (pp. 179-200). United Kingdom: A John Wiley \& Sons, Ltd, Publication.

- Bieschke, K.J.; Bishop, R.M.; \& Garcia, V.L. (1996). The Utility of the Research Self-Efficacy Scale. Journal of Career Assessment, 4 (1), 59 - 75.

- Bouffard-Bouchard, T. (1990). Influence of Self-Efficacy on Performance in a Cognitive Task. The Journal of Social Psychology, 130(3), 353-363.

- Brancolini, K.R. \& Kennedy, M.R. (2017). The development and use of a research self-efficacy scale to assess the effectiveness of a research training program for academic librarians. Library and Information Research, 41 (24), 44-84.

- Butler, A. (2008). Exploring the Role of Social reasoning and Self Efficacy in The Mathematics Problem Solving Performance of Low - and Middleses Children, Ph. D., Boston College. 
- Büyüköztürk, S.; Atalay, K.; Sozgun, Z.; \& Kebapçı, S. (2011). The Development of Research Self-Efficacy Scale. Cypriot Journal of Educational Sciences, 1, 22-29.

- Carifio, J. \& Rhodes, L., (2002). Construst Validities and Empirical Relationships Between optimism Hope, Self -Efficacy, and Locus of Control. Work, 19 (2), 125-136.

- Chandra, P. (2014). Cognitive Styles and Problem Solving Ability of Under Graduate Students. International Journal of Education and Psychological Research (IJEPR), 3 (2), 71-76.

- Curcio, F.R. \& Artzt, A.F. (1997). Assessing Students' Statistical Problem-solving Behaviors in a Small-group Setting. In I. Gal \& J.B. Garfield (Eds). The Assessment Challenge in Statistics Education, (pp 123138). IOS Press.

- Devi, K.R. \& Saravanakumar, AR. (2017). Cognitive Dissonance, Locus of Control, Self-efficacy and Academic Performance of Novice Teachers. Paripex - Indian Journal of Research, 6 (2), 198-199.

- Feldman, R.S.; Saletsky, R.D.; Sullivan, J. \& Theiss, A. (1983). Student Locus of Control and Response to Expectations about Self and Teacher. Journal of Educational Psychology, 75 (1), $27-32$. https://psycnet.apa.org/record/1983-11276-001

- Flores, F. J.; Mayorga-Vega, D.; Blanco, J.R.; \& Blanco, H. (2014). Perceived Self-Efficacy in Problem Solving and Scientific Communication in University Students. A Gender Study. Psychology, 5, 358-364. Retrieved from http://dx.doi.org/10.4236/psych.2014.55046.

- Forester, M.; Kahn, J.H.; \& Hesson-McInnis, M.S. (2004). Factor Structures of Three Measures of Research Self-Efficacy. Journal of Career Assessment, 12 (1), 3- 16.

- Geifman, D., \& Raban, D. R. (2015). Collective problem-solving: The role of self-efficacy, skill, and prior knowledge. Interdisciplinary Journal of eSkills and Life Long Learning, 11, 159-178. http://www.ijello.org/Volume11/IJELLv11p159-178Geifman1967.pdf

- Gelso,C.J.; Mallinckrodt, B. \& Judge, A.B. (1996). Research Training Environment, Attitudes Tawords Research, and Research Self-Efficacy: The Revised Research Training Environment Scale. The Counseling Psychologist, 24(2), 304 -322.

- Hoffman, B. (2006). The Influence of Self-Efficacy and Working Memory Capacity on Problem Solving Efficacy, $P h$. $D$., University of Nevada, Las Vegas.

- Jones, D. \& Jacobbe,T. (2014). An Analysis of the Statistical Content in Textbooks for Prospective Elementary Teachers. Journal of Statistics 
النموذج السبي للعلاقات بين القدرة على حل المشكلات الإحصائية وفاعلية الذات البحثية والتنافر المعرفي ووجهة الضبط لدى طلاب

د منال شمس الدين أحمد

Education,

22

(3),

مرحلة الدراسات العليا بكلبة التبية.

http://www.amstat.org/publications/jse/v22n3/jones.pdf.

1-18.

- Karbalaei, Abdollahi, Abu-Talib, Yaacob \& Ismail (2013). Romanian Journal of Applied Psychology, 15 (2), 51 -58.

- Konan, N. (2013). Relationship between Locus of Control and ProblemSolving Skills of High School Administrators. International Journal Social Science \& Education, 3 (3), 786-794.

- Marriott, J., Davies, N., and Gibson, L. (2009). Teaching, Learning and Assessing Statistical Problem Solving, Journal of Statistics Education, 17 (1). Retrieved

from http://www.amstat.org/publications/jse/v17n1/marriott.html.

- Miklosovic, J. C. (2010) "Cognitive dissonance: effects of perceived choice on attitude change,"Modern Psychological Studies, 15 (2), Article 3, 16-26. Retrieved from https://scholar.utc.edu/mps/vol15/iss2/3.

- Pajares, F. (1996). Self-Efficacy beliefs in Academic Settings. Review of Educational Research, 66 (4), 543-578.

- Phillips, J.C. \& Russell, R.K. (1994). Research Self-Efficacy, the Research Training Environment, and Research Productivity among Graduate Students in Counseling Psychology. The Counseling Psychologist, 22 (4), 628-641.

- Pretz, J.E., Naples, A.J., \& Sternberg, R.J. (2003). Recognizing, defining and representing problems. In J.E. Davidson \& R. J. Sternberg (Ed.), The Psychology of Problem Solving, (pp 3-30). Cambridge, UK: Cambridge University Press.

- Randles, D.; Inzlicht, M.; Proulx, T.; Tullett, A.M. \& Heine, S.J. (2015). Is Dissonance Reduction a Special Case of Fluid Compensation? Evidence that Dissonant Cognitions Cause Compensatory Affirmation and Abstraction. Journal of Personality and Social Psychology, 108 (5), 697-710.

- Şara, P. \& Kocabas, A. (2012). Correlation Between Learning and Studying Strategies, Problem Solving Abilities and Locus of Control Levels of Candidates of Primary School Teacher'. International Journal of New Trends in Arts, Sports \& Science Education, 1(1), 98-110.

- Soutar, G.N. \& Sweeney, J.C. (2003). Are There Cognitive Dissonance Segments? Australial Journal of Management, http://aum.sagepub.com/content/28/3/227.

- Tella, A.; Ayeni, C. \& Omba, O. (2007). Predictors of Academic Performance: Self-Efficacy and Use of Electronic Information. University of Dar Es Salaam Library Journal, 9 (1), 69-83. 
النموذج السبب للعلاقات بين القدرة على حل المشكلات الإحصائية وفاعلية الذات البحثية والتنافر المعرفي ووجهة الضبط لدى طلاب (S) منال شمس الدين أحمد مرحلة الدراسات العليا بكلية التربية.

- Wisniarti \& Sugiman, (2018). A Student's Cognitive Dissonance in Solving non-Routine Perimeter Problems. Journal of Physics: Conference Series, 1097(1), https://iopscience.iop.org/article/10.1088/17426596/1097/1/012099.

- Zheng, R.; McAlack, M.; Wilmes, B.; Evans, P. \& Williamson, J. (2009). Effects of Multimedia on Cognitive Load, Self Efficacy and Multiple rule based problem solving. British Journal of Educational Technology, 40(5), 790-803. 